\title{
Stratigraphy and Paleontology of Mid-Cretaceous Rocks in Minnesota and Contiguous Areas
}

GE O L O G I A L S UR V E Y PROFES I O NA L PAPER 1253

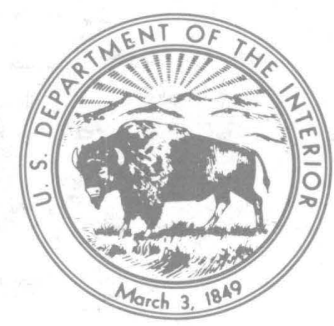




\section{Stratigraphy and Paleontology of Mid-Cretaceous Rocks in Minnesota and Contiguous Areas}

By William A. Cobban and E. A. Merewether

Molluscan Fossil Record from the Northeastern

Part of the Upper Cretaceous Seaway, Western Interior

By William A. Cobban

Lower Upper Cretaceous Strata in Minnesota and

Adjacent Areas-Time-Stratigraphic Correlations

and Structural Attitudes

By E. A. MEREWETHER

GEOLOGICAL SURVEY PROFESIONAL PAPER 1253 


\section{UNITED STATES DEPARTMENT OF THE INTERIOR}

JAMES G. WATT, Secretary

GEOLOGICAL SURVEY

Dallas L. Peck, Director

\footnotetext{
Library of Congress Cataloging in Publication Data

Cobban, William Aubrey, 1916

Stratigraphy and paleontology of mid-Cretaceous rocks in Minnesota and contiguous areas.

(Geological Survey Professional Paper 1253)

Bibliography: $52 \mathrm{p}$.

Supt. of Docs. no.: I 19.16

A. Molluscan fossil record from the northeastern part of the Upper Cretaceous seaway, Western Interior by William A. Cobban. B. Lower Upper Cretaceous strata in Minnesota and adjacent areas-time-stratigraphic correlations and structural attitudes by E. A. Merewether.

1. Mollusks, Fossil-Middle West. 2. Geology, Stratigraphic-Cretaceous. 3. Geology-Middle West. 4. Paleontology-Cretaceous. 5. Paleontology-Middle West. I. Merewether, E. A. (Edward Allen), 1930. II. Title. III. Series.

$\begin{array}{llll}\text { QE687.C6 } & 551.7^{\prime} 7^{\prime} 09776 & 81-607803 & \text { AACR2 }\end{array}$
}

For sale by the Distribution Branch, U.S. Geological Survey 604 South Pickett Street, Alexandria, VA 22304 


\section{CONTENTS}

[Letters designate chapters]

(A) Molluscan fossil record from the northeastern part of the Upper Cretaceous seaway, Western Interior ........

(B) Lower Upper Cretaceous strata in Minnesota and adjacent areas-time-stratigraphic cor-

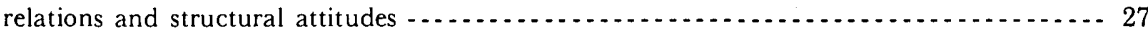





\section{Molluscan Fossil Record from the Northeastern Part of the Upper Cretaceous Seaway, Western Interior}

By William A. COBBAN

STRATIGRAPHY AND PALEONTOLOGY OF MID-CRETACEOUS ROCKS IN MIN NESOTA AND CONTIGUOUS AREAS

GEOLOGICAL SURVEY PROFESSIONAL PAPER 1253-A

Bivalves, ammonites, and a belemnite, from

Cretaceous bedrock and from glacial deposits,

represent at least 11 molluscan faunal zones of

Cenomanian to Santonian age that are present or

were present in Minnesota, eastern North and

South Dakota, northeastern Nebraska, and Iowa

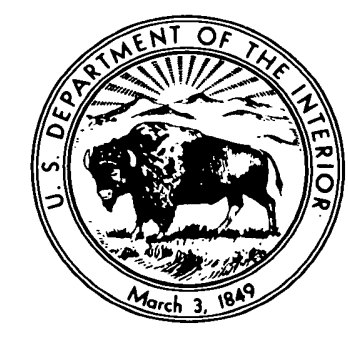





\section{CONTENTS}

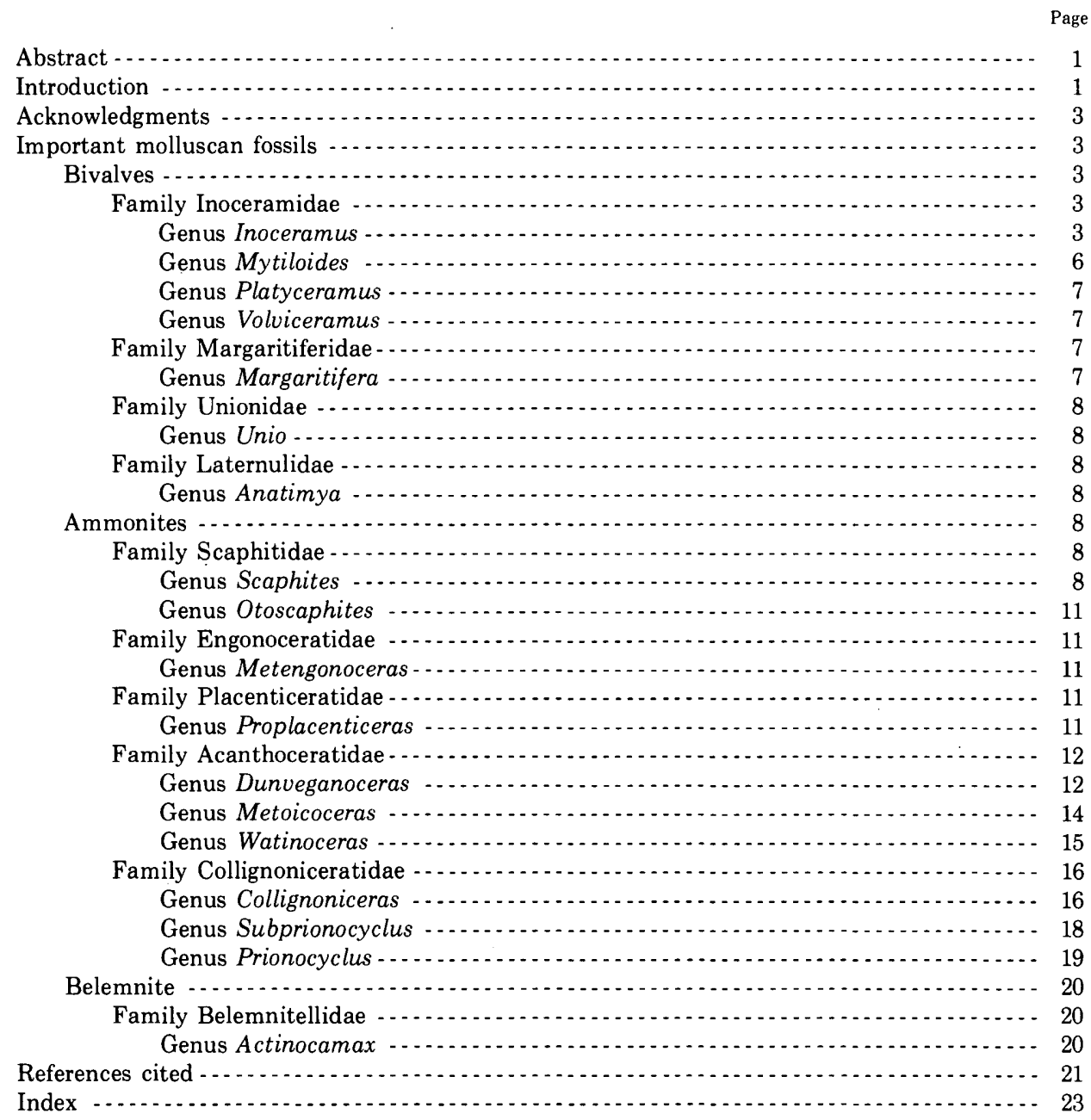




\section{ILLUSTRATIONS}

[Plates follow index of chapter A]

Plate 1. Turonian mollusks.

2. Cenomanian and Turonian bivalves.

3. Inoceramus.

4. Cenomanian bivalves.

5. Turonian ammonites.

6. Dunveganoceras and Metengonoceras.

7. Proplacenticeras, Metengonoceras, and Actinocamax.

8. Cenomanian, Turonian, and Coniacian mollusks.

9-11. Dunveganoceras.

12. Metoicoceras and Dunveganoceras.

13. Metoicoceras.

14. Cenomanian and Turonian mollusks.

15. Cenomanian, Turonian, and Coniacian mollusks.

FIgURE 1. Index map of important fossil collections

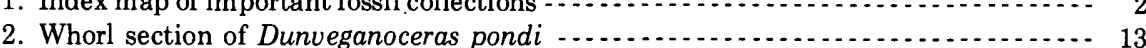

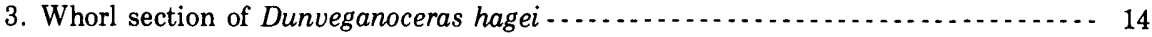

4. Whorl section of Dunveganoceras hagei $\ldots \ldots \ldots$

5. Map showing Localities of Actinocamax $\ldots \ldots \ldots \ldots$ 


\title{
STRATIGRAPHY AND PALEONTOLOGY OF \\ MID-CRETACEOUS ROCKS IN MINNESOTA AND CONTIGUOUS AREAS
}

\section{MOLLUSCAN FOSSIL RECORD FROM THE NORTHEASTERN PART OF THE UPPER CRETACEOUS SEAWAY, WESTERN INTERIOR}

\author{
By WLlliam A. CoBbaN
}

\begin{abstract}
Molluscan fossils are locally abundant at outcrops of Upper Cretaceous rocks in eastern North and South Dakota, northeastern Nebraska, northwestern Iowa, and western and northern Minnesota. Other Cretaceous mollusks have been found in the glacial deposits in Minnesota, Iowa, and Illinois.

The oldest well dated marine mollusks are of earliest late Cenomanian age and occur in northwestern Iowa. Mollusks of marginal marine and nonmarine environments in northwestern Iowa and south-central Minnesota are probably of slightly younger late Cenomanian age. The youngest mollusks treated in this report are bivalves of Santonian age found in the Niobrara Formation in eastern North and South Dakota.

The collections indicate the presence or former presence of the following ammonite zones in the northeastern part of the Western Interior seaway:

$\begin{array}{ll}\text { Santonian } & \left\{\begin{array}{l}\text { Scaphites depressus-Clioscaphites choteauensis } \\ \text { Coniacian }\end{array}\right. \\ & \left\{\begin{array}{l}\text { Scaphites ventrocosus } \\ \text { Scaphites preventricosus }\end{array}\right. \\ \text { Turonian } & \left\{\begin{array}{l}\text { Scaphites corvensis } \\ \text { Scaphites whitfieldi } \\ \text { Prionocyclus hyatti } \\ \text { Subprionocyclus percarinatus } \\ \text { Collignoniceras woollgari } \\ \text { Watinoceras coloradoense }\end{array}\right. \\ \text { Cenomanian } & \left\{\begin{array}{l}\text { Dunveganoceras albertense } \\ \text { Dunveganoceras pondi }\end{array}\right.\end{array}$
\end{abstract}

\section{INTRODUCTION}

Molluscan fossils of Cretaceous age from the east side of the Western Interior Cretaceous seaway were first described by Hall and Meek (1856), who named a new bivalve (Pectunculus [Sanoarca] siouxensis) and a new ammonite (Ammonites [Subprionocyclus] percarinatus) from beds now assigned to the Dakota Sandstone and Carlile Shale, respectively. Additional mollusks were treated in later reports by Meek and Hayden (1857, 1860), Meek (1871, 1873, 1876), and White (1894). Much later, Bergquist (1944) described a large assemblage of Cretaceous mollusks from the Mesabi Range, northern Minnesota (fig. 1). Since the completion of Bergquist's work, no new systematic papers concerning Cretaceous molluscan fossils in the northeastern part of the seaway have been published. The mollusks collected by J. N. Nicollet, "near the confluence of the Sioux and Missouri rivers, in a thick stratum of clay" (Morton, 1842, p. 212), are from the Pierre Shale and Fox Hills Formation at localities along the Missouri River in central and northcentral South Dakota, northwest of the area of the present report.

The oldest well dated molluscan fossils in the region investigated are from the top of the Dakota Formation and basal part of the overlying Graneros Shale at Sioux City, Iowa, where Dunveganoceras pondi Haas of earliest late Cenomanian age (in terms of a threefold division for the Cenomanian) was collected. The youngest molluscan fossils are from the Niobrara Formation of eastern North and South Dakota, where fragments of Platyceramus platinus (Logan) of Santonian age were found. Younger mollusks of Campanian age, derived from the Pierre Shale, have been found in the glacial drift in Minnesota and Iowa, but these are not included in this report.

With the exception of a new species and a new subspecies, this report is not a detailed systematic treatment of the molluscan faunas, but rather it is a generalized guide to the more common and important species. In most instances, synonymies include only the original report in which a species was named and one or two later reports that contain important changes in nomenclature or contain good illustrations. 
STRATIGRAPHY, PALEONTOLOGY, MID-CRETACEOUS, MINN.

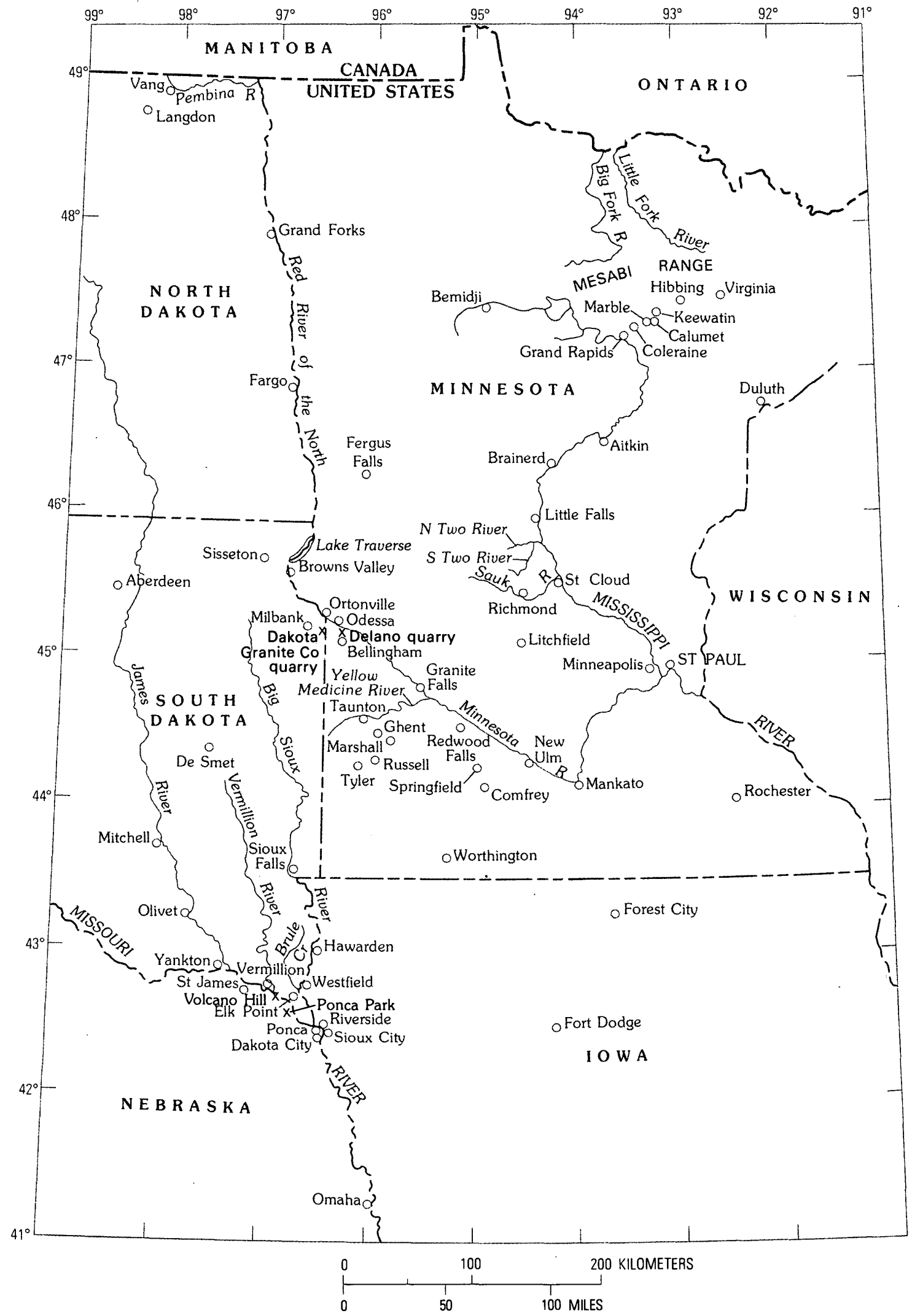

FIGURE 1.-Index map showing study area and localities of important fossil collections (x). 


\section{ACKNOWLEDGMENTS}

Much of this report could not have been prepared without the excellent collections of Cretaceous fossils (from the Mesabi Range and from the glacial drift of Minnesota) placed at my disposal by Professor R. E. Sloan, Department of Geology and Geophysics, University of Minnesota, Minneapolis. Professor F. D. Holland, Jr., and Professor A. M. Cvancara, Geology Department, University of North Dakota, Grand Forks, provided collections from the Carlile Shale of northeastern North Dakota as well as unpublished theses concerning these fossils. Professor D. G. Darby, Department of Geology, University of Minnesota, Duluth, loaned a very fine specimen of Dunveganoceras hagei from the Mesabi Range. Professor R. E. Stevenson, Department of Earth Science and Physics, University of South Dakota, Vermillion, kindly permitted study of collections from the Carlile Shale of southeastern South Dakota. Professor Karl M. Waagé, Peabody Museum of Natural History, Yale University, New Haven, Conn., loaned several ammonites and inoceramids collected by him and his students from the basal part of the Graneros Shale at Sioux City, Iowa, and he gave much helpful stratigraphic advice. Professor G. W. Shurr, Department of Physics (Earth Sciences), St. Cloud State College, St. Cloud, Minn., provided mollusks collected by him and his students from the Greenhorn and Carlile Formations of western Minnesota. Doctor A. S. Horowitz, Department of Geology, Indiana University, Bloomington, provided the large specimens of Inoceramus prefragilis stephensoni illustrated in this report. W. J. Schwarting, Director, Sioux City Public Museum, Sioux City, Iowa, kindly loaned the excellent specimens of Dunveganoceras pondi and Metengonoceras dumbli figurea in this report. David Jones, Jones Fossil Farm, Worthington, Minn., drew my attention to a splendid specimen of Prionocyclus found in the glacial drift by Timothy D. Holt, Marshall, Minn. James Stengel, Dakota Granite Company, Milbank, S. Dak., gave permission to collect from the company's quarries.

The photographs in this report and some of the fossil collections were made by Robert E. Burkholder, U.S. Geological Survey. Illustrated specimens having "USNM" catalog numbers are stored in the Museum of Natural History in Washington, D.C.

\section{IMPORTANT MOLLUSCAN FOSSILS}

The fossils treated on the following pages are mostly those that closely date the Cretaceous outcrops in the region as well as those that indicate the former presence of Cretaceous rocks. An exception are two species of ammonites new to the Western Interior.

Many of the figured specimens are at the Department of Geology and Geophysics, University of Minnesota, Minneapolis, and have the catalog abbreviations UMIP (University of Minnesota Invertebrate Paleontology). Other specimens are stored in the National Museum of Natural Science, Washington, D.C., and have USNM catalog numbers. Specimens at Peabody Museum of Natural History, Yale University, have YPM catalog numbers, and specimens at the Sioux City Public Museum, Sioux City, Iowa, have SCPM numbers. Plaster casts of a few of the figured specimens are kept in the U.S. Geological Survey's Mesozoic invertebrate collections at the Federal Center, Denver, Colo. Fossils from U.S. Geological Survey Mesozoic localities have catalog numbers preceded by USGS.

\section{BIVALVES}

Family INOCERAMIDAE Giebel, 1852

Genus INOCERAMUS J. Sowerby, 1814

Inoceramus fragilis Hall and Meek

Plate 1, figure 2

1856. Inoceramus fragilis Hall and Meek, American Academy of Arts and Sciences Memoirs, n. ser., v. 5, p. 388, pl. 2, figs. 6a, b. 1952. Inoceramus fragilis Hall and Meek. Stephenson, U.S. Geo(1953) logical Survey Professional Paper 242, p. 64, pl. 12, figs. 3, 4.

The holotype (Am. Mus. Nat. History 9358/1), refigured by Stephenson (1952, pl. 12, figs. 3, 4), is a small moderately convex right valve about as long as it is high; the hingeline is straight, and the beak is terminal and pointed. Ornamentation consists of rugae and evenly spaced growth lines. The specimen is on a piece of gray shale containing several impressions of the middle Turonian ammonite Subprionocyclus percarinatus (Hall and Meek) from “*** On the Missouri River, five miles below the mouth of Vermilion River. In the lower clay beds of division No. 2 of section" (Hall and Meek, 1856, p. 388). This locality, now known as Volcano Hill (fig. 1), but earlier called Ionia Volcano, is a splendid outcrop of Carlile Shale (Condra, 1908, p. 13).

In the course of mapping the Elk Point 30-minute quadrangle (S. Dak.-Nebr.-Iowa), J. E. Todd collected a fragment of a very fossiliferous gray limestone concretion from the Carlile Shale southwest of Vermillion on the south bank of the Missouri River in sec. 29, T. 32 N., R. 4 E., Dixon County, Nebr. (USGS 2989). This fragment (pl. 1, fig. 2) is remarkable in that one side contains many specimens of Inoceramus closely matching the holotype of $I$. fragilis. Like the holotype, the 
Inoceramus is associated with Subprionocyclus percarinatus. The opposite side of the fragment has parts of large specimens of Inoceramus cuvieri J. Sowerby. The holotype of $I$. fragilis and the small specimens in Todd's concretion, as well as other small specimens from the Carlile Shale of northern Dixon County, could be interpreted as juveniles of $I$. cuvieri. Adult specimens of $I$. cuvieri that have the beaks and umbonal part preserved are lacking in the collections from the Missouri River area; consequently, the two species names are retained for the present.

Type.-Hypotype USNM 299138.

\section{Inoceramus prefragilis stephensoni Kauffman and Powel}

Plate 2, figures 19,20 ; plate 3

1977. Inoceramus prefragilis stephensoni Kauffman and Powell, Geological Society of America Memoir 149, p. 62, pl. 2, figs. $1,3,6,8,10$.

The types of Inoceramus prefragilis stephensoni (USNM 169325-169332) are from the lower part of the Lincoln Limestone Member of the Greenhorn Formation in the Oklahoma Panhandle. The types of I. prefragilis prefragilis Stephenson (USNM 105151-105156) are from the Lewisville Member of the Woodbine Formation in Grayson County, northern Texas.

Stephenson (1952, p. 64, pl. 12, figs. 10-12; pl. 13, figs. $1,2)$ characterized $I$. prefragilis prefragilis as

Adult shell large, moderately inflated, higher than long, strongly inequilateral, slightly inequivalve. Beaks terminal, prominent, strongly incurved, prosogyrate $* * *$ shell most prominently inflated in the umbonal region. ${ }^{* * *}$ The posterior slope [of the shell] may or may not bear one or two broad, shallow radial depressions.*** Surface of medium-sized specimens ornamented all over, or nearly so, with closely spaced low, narrow, concentric ribs and may or may not exhibit irregular, broad growth undulations. The narrow concentric markings are most sharply and regularly developed in the umbonal region, with a tendency to become less regular ventrally; on large individuals the surface away from the umbonal region is almost without the narrow concentric markings, presenting instead coarse, irregular undulations.

Stephenson's types were associated with a diversified assemblage of bivalves and gastropods but no ammonites. Ammonites were not listed by Stephenson from the Lewisville Member of the Woodbine Formation in Grayson County. However, from the overlying Templeton Member of the Woodbine in Grayson County, Stephenson (1952, p. 201-210) recorded Acanthoceras hazzardi Stephenson, A. cuspidum Stephenson, Mammites? bellsanus Stephenson, Metengonoceras dumbli (Cragin), Metoicoceras swallovii (Shumard), $M$. latoventer Stephenson, and M. crassicostae Stephenson. Acanthoceras hazzardi Stephenson $(1952$, p. 201) is a synonym of $A$. amphibolum Morrow (1935, p. 470), and
Mammites? bellsanus Stephenson (1952, p. 204) may be an example of Plesiacanthoceras wyomingense (Reagan, 1924 , p. 181). Accordingly, the types of $I$. prefragilis prefragilis are probably from some zone older than that of $A$. amphibolum. In Kansas A. amphibolum occurs in the uppermost part of the Graneros Shale, and in Colorado, where the Graneros-Greenhorn contact is drawn a little higher, $A$. amphibolum occurs in the uppermost part of the Graneros Shale and in the basal part of the Lincoln Limestone Member of the Greenhorn Formation.

Inoceramus prefragilis stephensoni differs from $I$. prefragilis prefragilis in having a broader and flatter shell without the shallow posteroventral radial sulci and in having the regular concentric ornamentation persisting throughout most of the growth. In the Western Interior, I. prefragilis stephensoni occurs in the Cenomanian zones of Plesiacanthoceras wyomingense and Dunveganoceras pondi.

Large inoceramids in the Graneros Shale along the Missouri River valley in northeastern Nebraska and northwestern Iowa are referred to I. prefragilis stephensoni. A slab of siltstone from the Sioux City Brick and Tile Company's claypit at Riverside, Iowa, has excellent specimens more than $140 \mathrm{~mm}$ in height (pl. 3). Other localities where the subspecies occurs are in the claypit in the NW $1 / 4 \mathrm{SE}^{1 / 4} \mathrm{sec} .14, \mathrm{~T} .89 \mathrm{~N}$., R. $48 \mathrm{~W}$., at Riverside (USGS D10405); west of Dakota City in the SW $1 / 4 N^{1 / 4}$ sec. 20 , T. 28 N., R. 8 E., Dakota County, Nebr. (USGS D10402); at Ponca State Park in the SE $1 / 4$ sec. 3, T. 30 N., R. 6 E., Dixon County, Nebr. (USGS D10403); and in the SW $1 / 4 \mathrm{NW}^{1 / 4}$ sec. 4 , T. 90 N., R. 48 W., Plymouth County, Iowa (USGS D10412).

Fragments of inoceramids that may be $I$. prefragilis stephensoni were found farther northwest at an excavation southeast of Mitchell in the $\mathrm{SE}^{1 / 4} \mathrm{NE}^{1 / 4} \mathrm{sec} .8, \mathrm{~T} .102$ N., R. 59 W., Hanson County, S. Dak. (USGS D10701). Here, bluish-gray clay shale, distorted by glacial action and possibly included in the drift, rests on the Precambrian Sioux Quartzite. Palynomorphs in the shale were reported on by R. H. Tschudy as follows (written commun., July 1979):

In addition to the marine forms, dinoflagellates, acritarchs, and Pterospermopsis, very few palynomorphs of terrestrial origin were present. The following poorly preserved taxa were found: Taxodiaceaepollenites Araucariacites Equisetosporites Bisaccate conifer pollen Pristinuspollenites Tricolpites reticulate, small Tetracolpites smooth, small Trilete spores-very few Schizosporis reticulatus Cookson and Dettmann. 
The presence of small specimens of Tricolpites and Tetracolpites indicates an age no older than middle Albian. The presence of Schizosporis reticulatus Cookson and Dettmann indicates an age no younger than Cenomanian. This species has not been found in rocks younger than Cenomanian nor older than Berriasian anywhere in the world.

Types.-Hypotypes USNM 299147; YPM 14895, 14896.

Inoceramus ginterensis Pergament

Plate 2, figures 17,18

1966. Inoceramus ginterensis Pergament, Transactions of the Geological Institute of the Academy of Sciences of USSR, v. 146 , p. 50 , pl. 25 , fig. 5 ; pl. 26 , figs. 1,2 ; pl. 27 , figs. 1,2 ; pl. 28 , figs. 1,2 ; pl. 29 , fig. 1 .

1977. Inoceramus ginterensis Pergament. Kauffman and Powell, Geological Society of America Memoir 149, p. 64, pl. 1, fig. 2 ; pl. 3 , figs. $1-4,6$; pl. 4 , figs. $1,3-6$; pl. 5 , figs. $2,3,5$; pl. 7 , fig. 4 .

This species resembles Inoceramus prefragilis Stephenson in size, outline, and convexity. The ornamentation, however, differs considerably; I. ginterensis has rugae of irregular strength and spacing, and the umbonal area may be bounded by a concentric sulcus. Evenly spaced growth lines may or may not be present on the umbonal area.

Inoceramus ginterensis was originally described from Cenomanian rocks in northwestern Kamchatka and southern Sakhalin, U.S.S.R. (Pergament, 1966). The species is widely distributed in the Western Interior in the late Cenomanian zone of Dunveganoceras albertense (Warren).

Septarian limestone concretions in the upper part of the Graneros Shale along the Missouri River valley in northwestern Iowa contain $I$. ginterensis (USGS D10503). These specimens closely resemble those illustrated by Pergament (1966, pls. 25-29).

Types.-Hypotypes USNM 299145, 299146.

Inoceramus mesabiensis Bergquist

Plate 2, figures $7,8,11,12$

1944. Inoceramus fragilis mesabiensis Bergquist, Journal of Paleontology, v. 18 , no. 1 , p. 12 , pl. 5 , figs. $3-6,8$.

This moderately small inequivalved late Cenomonian inoceramid is characterized by its great convexity, subrectangular outline, height greater than length, steep anterior and posterior edges, and prominent beaks curved inward and anteriorly. The hingeline is straight and set at a high angle to the rest of the shell. Ornamentation consists of inconspicuous growth lines and more prominent rugae of irregular spacing and height.

Bergquist's types (UMIP 5019, 5019a-c) came from ferruginous conglomerate in the basal part of the Coleraine Formation at the Hill Annex mine in the Mesabi Range at Calumet, Minn. Ammonites from the bed of conglomerate at this mine were described by Bergquist (1944, p. 29, 30) as Metoicoceras aff. M. swallovi (Shumard) [M. bergquisti Cobban, n. sp.], Epengonoceras [Metengonoceras] cf. E. dumbli (Cragin), and Metacalycoceras? sp. and Acanthoceras sp. [both Dunveganoceras hagei Warren and Stelck]. Well-preserved internal molds of dark-brown, very fine grained ferruginous sandstone occurred in the Coleraine Formation in the Bennett open-pit iron mine at Keewatin, Minn. (USGS 13766), and two of these specimens are shown on plate 2, figures 7, 8, 11, 12 .

Typical specimens of $I$. mesabiensis have not been found in the Western Interior outside the Mesabi Range. A closely related smaller and less convex subspecies occurs in the zone of Dunveganoceras albertense (Warren) in the Frontier Formation along the west and south flanks of the Powder River Basin in Wyoming and in the Hartland Shale Member of the Greenhorn Formation along the east side of the basin. Similar specimens occur in the zone of Dunveganoceras albertense as far north as north-central Montana (Cobban and others, 1976, p. 39).

Types.-Hypotypes USNM 299143, 299144.

Inoceramus apicalis Woods

Plate 2, figures 1-6, 9, 10; plate 8 , figure 10

1912. Inoceramus lamarcki var. apicalis Woods, Palaeontographical Society Monograph, v. 65, p. 319, pl. 53, figs. 4-6.

Inoceramus apicalis Woods is a moderately small inequivalved species that is very inequilateral, narrow, much inflated, and ornamented by regular concentric growth lines and (or) lamellae with occasional rugae. The hingeline is straight and long and forms a very high angle with the rest of the shell. The posterior auricle, which is well developed and subtriangular, is separated from the rest of the shell by a marked change in the postumbonal slope.

The types of $I$. apicalis came from the upper part of the Middle Chalk of England (upper Turonian). Specimens that seem assignable to I. apicalis occur with Collignoniceras woollgari regulare (Haas) in the silty limestone resting on Precambrian granite in the Dakota Granite Company's quarry (fig. 1) east of Milbank, S. Dak. (USGS D10415, SW1/4 sec. 18, T. 120 N., R. 47 W., Grant County). Specimens also occur with Subprionocyclus percarinatus (Hall and Meek) in limestone concretions in the Carlile Shale at Volcano Hill (USGS D10404) in sec. 3, T. 31 N., R. 5 E., Dixon County, Nebr.

Types.-Hypotypes USNM 299139-299142, 299178. 
Inoceramus howelli White

Plate 2, figures 13-16

1876. Inoceramus howelli White. Powell, U.S. Geological and Geographical Survey of the Territories, p. 114.

1879. Inoceramus howelli White. White, U.S. Geological and Geographical Survey of the Territories, 11th Annual Report, p. 284 , pl. 4 , fig. 1a-c.

1893. Inoceramus fragilis Hall and Meek (part). Stanton, U.S. Geo(1894) logical Survey Bulletin 106, p. 76, pl. 11, figs. 3-5 only.

This moderate-sized inequivalved species is easily recognized by its prominent posteroventral fold bounded by well-defined sulci. The shell is moderately convex, and its height is greater than its length. The hingeline is straight and conspicuous. Ornamentation consists of low rugae of irregular strength and spacing.

Inoceramus howelli is an important guide fossil to the middle Turonian zone of Prionocyclus hyatti (Stanton). White's types came from the lower sandstone member of the Straight Cliffs Formation (Peterson and Waldrop, 1965, fig. 3) in the Lower Potato Valley west of Escalante in southern Utah. The species is widely distributed in the Western Interior.

Many well-preserved specimens of Inoceramus howelli were found in a large boulder of very fine grained ferruginous sandstone in the glacial drift across the street from the Yellow Medicine County Museum in Granite Falls, Minn. The specimens very closely resemble White's types in size, form, and ornamentation. Most of the boulder is on display at the County Museum, but good specimens from it are in the collections of the University of Minnesota, Minneapolis.

Types.-Hypotypes UMIP 9000a, 9000b.

Inoceramus cuvieri J. Sowerby

1822. Inoceramus cuvieri J. Sowerby, Transactions of the Linnean Society of London, v. 13, p. 453, pl. 25.

The lectotype of the Turonian Inoceramus cuvieri J. Sowerby, refigured by Woods (1912, text fig. 73), is a left valve about $113 \mathrm{~mm}$ high that is characterized by its suberect form, a height greater than its length, fairly low convexity, and ornamentation of evenly to subevenly spaced lamellae and a few low rugae. The specimen is from the Middle Chalk of England.

Fragments of large inoceramids that have low convexity and fairly evenly spaced flat lamellae occur in the Carlile Shale in northeastern Nebraska (USGS 2984, 2989, D10404). These fragments are interpreted as pieces of large individuals of $I$. cuvieri. Hattin (1962, pls. 15, 21) noted similar-sized flattened specimens of $I$. cuvieri in the Carlile Shale of Kansas.
Genus MYTILOIDES Brongniart, 1822

Mytiloides mytiloides (Mantell) s.l.

Plate 1, figure 1; plate 8 , figures 8,9

1822. Inoceramus mytiloides Mantell, the fossils of the South Downs, or illustrations of the geology of Sussex: London, Lupton Relfe, p. 215 , pl. 28 , fig. 2.

For synonymy and other illustrations, see Kauffman and Powell, 1977, Geological Society of America Mem. 149, p. 74, 76.

This thin-shelled species is characterized by its elongate form, low convexity, conspicuous posterior auricle, and distinctive ornamentation, usually consisting of more or less evenly spaced rugae and raised growth lines on the rugae as well as in the space between rugae. The hingeline is straight, and the shell axis is strongly inclined to it. Mytiloides mytiloides is the species usually referred to as Inoceramus labiatus (Schlotheim) in Cretaceous literature, although the latter species does occur (pl. 8, fig. 7). In the Western Interior, $M$. mytiloides occurs in vast numbers in the upper part of the Bridge Creek Limestone Member of the Greenhorn Formation. At Pueblo, Colo., the species is especially abundant and well preserved in bed 113 of Cobban and Scott (1972, pl. 41) where it is associated with Mammites nodosoides (Schlotheim), Choffaticeras pavillieri (Pervinquière), and other ammonites of late early Turonian age.

Specimens referable to Mytiloides mytiloides s. l. are abundant in thin beds of limestone in the Greenhorn Formation along the Missouri River in northeastern Nebraska and northwestern Iowa, as well as in scattered outcrops in southeastern South Dakota and southwestern Minnesota. The valves occur separated, and most are in the $60-120 \mathrm{~mm}$ range in length (pl. 1, fig. 1). Along the Missouri River (USGS D10406, D10502) and along the lower reaches of the Big Sioux River (USGS D10413), $M$. mytiloides occurs in a bluff-forming sequence of thin beds of hard limestone and softer chalk and calcareous shale that could be referred to the Bridge Creek Limestone Member of the Greenhorn Formation. Mollusks, other than $M$. mytiloides, are extremely sparse in these beds. Similar Bridge Creek like beds, that contain abundant $M$. mytiloides, are well exposed along Brule Creek in the SW $1 / 4 \mathrm{SW}^{1 / 4}$ sec. 7 and $\mathrm{NE}^{1 / 4} \mathrm{NW}^{1 / 4}$ sec. 18 , T. 92 N., R. 49 W., Union County, S. Dak. (USGS D10703, D10411). At the western boundary of Minnesota, Bridge Creek like beds containing $M$. mytiloides crop out on the shore of Lake Traverse (Shurr, 1979, USGS D10372). Farther southeast, in the Ortonville-Bellingham area of Minnesota, $M$. mytiloides is abundant in hard thin beds of limestone of Bridge Creek lithology that rest on Precambrian granite (USGS D10373, D10706). The fossil recorded as Inoceramus barabina Morton by Sloan (1964, p. 15) from 
one of the granite quarries is probably $M$. mytiloides, unless it represents a specimen derived from the Pierre Shale in the glacial drift. At this quarry, south of Odessa, Minn., in the NE $1 / 4 \mathrm{SE}^{1 / 4}$ sec. 32, T. 121 N., R. $45 \mathrm{~W}$. (USGS D10373), thin beds of limestone resting on the granite contain abundant pelagic foraminifers, barnacle plates, fish scales, bones, and teeth, as well as $M$. mytiloides, Ostrea sp., and a brachiopod identified by J. T. Dutro, Jr., as probably a new species of Discinisca (Discradisca). A fissure filling of hard, sandy limestone in the granite at the Delano quarry, a few kilometers to the southeast in the $\mathrm{SE}^{1 / 4} \mathrm{SE} 1 / 4$ sec. 16 , T. 120 N., R. 45 W. (USGS D10420), contains fragments of $M$. mytiloides associated with Amphidonte? sp., Discinisca (Discradisca) sp., fish scales and bones, and shark teeth. Type.-Hypotype USNM 299137.

\section{Genus PLATYCERAMUS Heinz, 1932}

Platyceramus platinus (Logan)

1898. Inoceramus platinus Logan, Kansas University Geological Survey, v. 4, pt. 8, p. 491 [not pl. 116].

1964. Inoceramus platinus Logan. Scott and Cobban, U.S. Geological Survey Professional Paper 454-L, pl. 9.

This inoceramid is very large, flat, about as long as it is high, and ornamented by concentric rugae of irregular height and spacing. The hingeline is straight and long, and the beak is located at its anterior end. A very large size is attained by this species; a magnificent specimen on display in the Fort Hays State College Museum, Hays, Kans., is about a meter in height (Moore, 1958, fig. 16.19; Miller, 1968, pl. 3, fig. 1).

Platyceramus platinus is abundant in the Niobrara Formation in the Great Plains region. Fragments, encrusted by the oyster Pseudoperna congesta (Conrad), occur on Niobrara outcrops in eastern North Dakota, southeastern South Dakota, and northeastern Nebraska. The species may range throughout the Santonian (Scott and Cobban, 1964, p. L5).

Genus VOLVICERAMUS Stoliczka, 1871

Volviceramus involutus (J. de C. Sowerby)

Plate 15, figures 13,14

1828. Inoceramus involutus J. de C. Sowerby, The mineral conchology of Great Britain, v. 6 , p. 160 , pl. 583, figs. $1-3$

1871. Inoceramus (Volviceramus) involutus Sowerby. Stoliczka, The Cretaceous fauna of southern India, v. 3, The Pelecypoda, India Geological Survey Memoirs, Paleontologia Indica, p. 394,401

Volviceramus involutus is a moderate-sized species that is very inequilateral and extremely inequivalve. The left valve is much larger than the right one, very inflated, spirally coiled, and nearly smooth. The right valve has a nearly oval outline and a very low convexity; it is ornamented by conspicuous concentric rugae.

The holotype of $V$. involutus is from the Upper Chalk of England. Specimens that seem referable to this species occur in the lower part of the Smoky Hill Shale Member of the Niobrara Formation in southeastern Colorado (Scott and Cobban, 1964, p. L5, L9-L13) and in the equivalent part of the Niobrara Formation in the central Great Plains as well as in age-equivalent rocks in north-central Montana (Cobban, 1955, p. 204, pl. 2, figs. 6-9; Cobban and others, 1976, p. 59). The species is most abundant in the late Coniacian zone of Scaphites ventricosus Meek and Hayden.

Volviceramus involutus was recorded by Hattin (1975, p. 205 , pl. 3, fig. 7 ) as $V$. grandis (Conrad), from chalky limestone 1.5-2.7 $\mathrm{m}$ above the base of the Niobrara Formation, north of St. James in northeastern Nebraska (NW $1 / 4$ sec. 7, T. 32 N., R. 3 E.). Specimens occur in the same part of the Niobrara Formation about $12 \mathrm{~km}$ farther northwest (pl. 15, figs. 13, 14). Outcrops of the Niobrara Formation far to the north, in northeastern North Dakota, also contain V. involutus (USGS D10419, NW $1 / 4$ sec. 34, T. 163 N., R. 57 W., Cavalier County).

Type.-Hypotype USNM 299191.

Family MARGARITIFERIDAE Haas, 1940 Genus MARGARITIFERA Schumacker, 1816

Margaritifera cf. M. nebrascensis (Meek)

Plate 4, figures 6-8

Two large well-preserved clams from the Cenomanian Dakota Formation at the mouth of Two River in sec. 8, T. 127 N., R. 29 W., Morrison County, Minn. (fig. 1), may represent Margaritifera nebrascensis (Meek). This species was originally described as Unio (Baphia?) nebrascensis Meek (1871, p. 303). No illustrations were given. Later Meek (1876, p. 114, pl. 1, fig. 5a-c) illustrated it and assigned it to Margaritana. Much later, Henderson (1935, p. 68) placed it more correctly in Margaritifera.

Meek's species was originally based on two specimens, a large inflated one, regarded as the holotype by White (1883, p. 427), and a much smaller internal mold. These specimens, the only ones figured for the species, came from the Dakota Formation near Dakota City, Nebr. The holotype is characterized by its elongate rhomboid outline, inflated shell, prominent beaks situated near the anterior end, sinuous ventral margin, and a conspicuous ridge that extends from the umbo to the posteroventral margin paralleled by a much weaker fold. The specimens from Two River, first noted by Upham (1888, p. 602), are more inflated than the holotype and lack the second (lower) umbonal-posteroventral fold. These differences 
may just be intraspecific variations. The specimens also show considerable resemblance to Ambonicardia cookii Whitfield (1885, p. 25, pl. 11, figs. 11-14) from the Raritan Formation of New Jersey.

The specimens from Two River are limonitic and probably came from a ferruginous bed or from clay ironstone concretions in a bed of gray clay. Only 1 or $2 \mathrm{~m}$ of the Dakota Formation are exposed (Stauffer and Thiel, 1941, p. 175).

The specimens are in the collections of the Department of Geology and Geophysics, University of Minnesota, Minneapolis.

Figured specimen.-UMIP 4567.

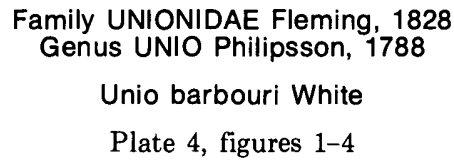

1894. Unio barbouri White, U.S. National Museum Proceedings, v. 17, no. 995, p. 133, pl. 8, figs. 1-3.

This bivalve, originally described from the Cenomanian Dakota Formation near Fairbury, Nebr., has an elongate outline, beaks located near the anterior end, and a nearly smooth shell. Several specimens, from Cretaceous rocks at the mouth of Two River in sec. 8, T. 127 N., R. 29 W., Morrison County, Minn., are in the collections of the Department of Geology and Geophysics, University of Minnesota, Minneapolis (Stauffer and Thiel, 1941, p. 101). The specimens have the same ferruginous preservation as that of the individuals of Margaritifera cf. $M$. nebrascensis and were probably found with them.

Types.-Hypotypes UMIP 4566a, 4566b.

\section{Family LATERNULIDAE Hedley, 1918 Genus ANATIMYA Conrad, 1860 \\ Anatimya plicata Bergquist}

Plate 4, figure 5

1944. Anatimya plicata Bergquist, Journal of Paleontology, v. 18, no. 1, p. 21, pl. 1, figs. $1,2,5$.

The types came from a conglomerate in the Coleraine Formation at the Arcturus iron mine in Marble, Minn. The species is large for the genus and differs from the type of the genus, Anatimya anteradiata Conrad (1860, p. 276 , pl. 46 , fig. 3 ), in having a subovate to subelliptical outline instead of a rectangular one.

A single specimen was found in the Cretaceous rocks in the Ochs Brick and Tile Company's claypit near Springfield in the NE $1 \frac{1}{4}$ sec. $26, T$ T. 109 N., R. 35 W.,
Brown County, Minn. Although the specimen is distorted, it shows enough features to assign it to Bergquist's species. The specimen retained its nacreous shell, which overlies a ferruginous clay siltstone filling. The presence of $A$. plicata in the Ochs claypit is of considerable interest in that it indicates marginal marine conditions in this part of Minnesota in late Cenomanian time. The specimen is in the collections of the Department of Geology and Geophysics, University of Minnesota, Minneapolis.

Type.-Hypotype UMIP 9001.

\section{AMMONITES \\ Family SCAPHITIDAE Meek, 1876 Genus SCAPHITES Parkinson, 1811 \\ Scaphites delicatulus sloani Cobban, n. subsp. \\ Plate 5, figures $12-15,18-23$}

Scaphites delicatulus Warren (1930a, p. 66, pl. 3, fig. 3 , pl. 4, figs. 7,$8 ; 1947$, p. 123 , pl. 29, fig. 5) is a stout, moderately sized scaphite that has fairly abundant, uniformly spaced primary and secondary ribs and a row of nodate ventrolateral tubercles. The cotypes came from the Smoky River Shale in the Peace River area of Alberta, Canada, and the specimen later illustrated by Warren came from the Mackenzie River area farther north. Several well-preserved adults from the Seabee Formation on the north slope of Alaska were illustrated by Cobban and Gryc (1961, pl. 37, figs. 16-24; text fig. $2 a, b, o)$. Rib counts on the last complete whorl of six adult specimens from the Seabee Formation gave a range of from 18 to 25 primaries and from 71 to $87 \mathrm{sec}-$ ondaries (Cobban and Gryc, 1961, table 2).

Scaphites delicatulus sloani, n. subsp., differs from the typical form of the species in having more ribs and weaker tubercles, as well as in having or tending to have a smooth area on the body chamber that separates the primary ribs from the row of ventrolateral tubercles. The holotype is an internal mold on an adult that has a height of $36 \mathrm{~mm}$ and a thickness of $18.5 \mathrm{~mm}$. Ten closely spaced primary ribs are present on the body chamber. On the older half of the body chamber, the primary ribs begin at the umbilical shoulder and curve forward on crossing the inner part of the flank. Most ribs disappear before reaching the row of ventrolateral tubercles. These tubercles are small, low, and rounded; they are strongest near the base of the body chamber and weaken and disappear near the middle. Two or three secondary ribs begin at each tubercle, and each group is separated by three or four other secondaries. A total of 63 secondary ribs is present on the body chamber. The visible part of the last septate whorl has 12 primary ribs and $42 \mathrm{sec}-$ ondaries. The secondary ribs trend straight across the 
venter on most of the body chamber, but on the oldest part, as well as on the outer septate whorl, the ribs bend backward a little where they cross the venter.

The holotype of $S$. delicatulus sloani came from the hard concretionary limestone overlying Precambrian granite at the Dakota Granite Company's quarry east of Milbank, in the SW $1 / 4$ sec. 18 , T. 120 N., R. 47 W., Grant County, S. Dak. (USGS D10415). Twelve specimens, mostly phragmocones, were available for study. The phragmocones have simple sutures much like that of the type of S. delicatulus (Warren, 1930a, pl. 3, fig. 3).

Scaphites delicatulus ranges from the latest Cenomanian to the middle Turonian. The oldest form, $S$. delicatulus greenhornensis Cobban (1951, p. 18, pl. 1, figs. 1-3), occurs in the Sciponoceras gracile Range Zone. The typical form of the species seems to be confined to the early Turonian; whereas, the subspecies sloani is associated with Collignoniceras woollgari regulare (Haas) of middle Turonian age.

Types.-Holotype USNM 299155, paratypes USNM 299156-299158.

Scaphites patulus Cobban

Plate 1, figure 2 (part)

1951. Scaphites patulus Cobban, U.S. Geological Survey Professional (1952) Paper 239, p. 20, pl. 1, figs. 23-32.

A depressed body chamber whorl, sparse ribbing, and a row of nodes characterize this species. The type lot is from limestone concretions in the lower part of the Carlile Shale on the east flank of the Black Hills in western South Dakota. These specimens have, on the adult body chamber, 5-8 primary ribs terminating in nodes or bullae and 21-27 secondary ribs. Recently, some excellent specimens, associated with Subprionocyclus percarinatus (Hall and Meek), were found in the Carlile Shale on the south side of the Black Hills by Neal L. Larsen, Black Hills Institute of Geological Research, Hill City, S. Dak. These included adults as much as $40 \mathrm{~mm}$ in length.

A small adult (pl. 1, fig. 2) is present in the limestone concretion from the Carlile Shale collected by J. E. Todd near the old Vermilion ferry crossing in sec. 29 , T. $32 \mathrm{~N}$., R. 4 E., Dixon County, Nebr. (USGS 2989). The body chamber is complete, but much of the phragmocone has been eroded. Five primary ribs and 20 secondaries are present on the body chamber. Associated fossils include Subprionocyclus percarinatus, Inoceramus fragilis, I. cuvieri, and large fish scales; all are of middle Turonian age.

Type.-Hypotype USNM 299138.
Scaphites corvensis Cobban

Plate 5, figures 24,25

1951. Scaphites corvensis Cobban, U.S. Geological Survey Profes(1952) sional Paper 239, p. 26, pl. 7, figs. 6-10.

A very well preserved nacreous-shelled adult scaphite was found in a clay ironstone concretion in a Minnesota Department of Conservation's water well, about $7 \mathrm{~km}$ north of Russell in Camden State Park (NE1/4 SE1/4 sec. 32, T. 111 N., R. 42 W., Lyon County). This specimen, nearly $60 \mathrm{~mm}$ in length, has 10 primary ribs and 40 secondary (ventral) ribs on the body chamber. An umbilical swelling is present at the base of the body chamber, which, together with the inflated form of the shell, suggests a female (Cobban, 1969, p. 7).

The holotype of $S$. corvensis, which came from the Carlile Member of the Cody Shale in Bighorn County, Mont., is about the same size as the Minnesota specimen but is more slender. Primary ribs on the body chamber number 15 and the secondaries number 52 . Specimens from the Frontier Formation of Wyoming reveal a considerable range in form and size of the shell and in the number of ribs on the body chamber. Some Wyoming individuals are as stout as the Minnesota specimen.

Scaphites corvensis is a transitional form between $S$. nigricollensis Cobban of late Turonian age and $S$. preventricosus Cobban of early Coniacian age. Scaphites corvensis is ordinarily found with Prionocyclus quadratus Cobban, which identifies the youngest of several zones of Prionocyclus and is of latest Turonian age. However, $S$. corvensis has been found recently with Forresteria (Texasia) cf. F. (T.) dentatocarinatum (Roemer) of a post-Prionocyclus, very early Coniacian age. This late form of $S$. corvensis was found in the uppermost part of the Frontier Formation in Fremont County, Wyo. Associated fossils include Inoceramus frechi Flegel, which has been recorded from both upper Turonian and Coniacian rocks in Europe.

The Minnesota specimen is either from Cretaceous shale or from the overlying glacial drift. The specimen was said to have come from some depth "between 164 and 230 feet" (50-70 m). Inasmuch as the surface elevation of the borehole was reported as $1,387 \mathrm{ft}(423 \mathrm{~m})$, and the contact of the glacial drift with the Cretaceous shale was given as $1,219 \mathrm{ft}$ ( $372 \mathrm{~m}$ ) (Rodis, 1963, fig. 5), the interval 164-230 ft includes the basal part of the drift and more than $18 \mathrm{~m}$ of Cretaceous shale. The drill hole had a 9-in. diameter $(23 \mathrm{~cm})$ (Rodis, 1961, table 2), and presumably the small concretion ( $103 \mathrm{~mm}$ in length) containing the scaphite fell into the bailer. The concretion is unweathered and lacks abrasions; if it came from the drift, it was derived from nearby Cretaceous shale. The shale in the borehole may represent the uppermost 
part of the Carlile Shale. Rodis (1963, p. N15, fig. 5) recorded thick-bedded limestone beneath the glacial drift in an area beginning about $7 \mathrm{~km}$ northwest of the borehole. This limestone, which I interpret as a remnant of the basal part of the Niobrara Formation, lies at elevations between 378 and $384 \mathrm{~m}$ (Rodis, 1963, p. N15). Inasmuch as the Cretaceous rocks are flat lying in Lyon County, the contact of the Cretaceous shale with the glacial drift in the borehole should be within $6 \mathrm{~m}$ of the base of the projected Niobrara Formation. If no significant hiatus occurs at the base of the Niobrara, the shale in the borehole may represent some upper part of the Carlile Shale, such as an equivalent of the Sage Breaks Member of the Carlile on the northeast flank of the Black Hills. Such a Sage Breaks age (latest Turonian) would fit the identification of the scaphite. However, Bolin (1956, p. 282) recorded Niobrara foraminiferids from an outcrop $17 \mathrm{~km}$ north of the borehole (sec. 7, T. 113 N., R. 42 W., Lyon County), which should be at a lower stratigraphic position than that of the scaphite. Yellow, very fine grained, calcareous sandstone crops out along the South Branch of Yellow Medicine River in the $\mathrm{NW}^{1 / 4}$ sec. 7 at an elevation between 338 and $341 \mathrm{~m}$. However, Winchell (1874, p. 189) mentioned an outcrop of yellowish-weathering, blue clay "at least ten or fifteen feet" thick "up a little creek that comes into the Yellow Medicine river from the south." The presence of Niobrara foraminiferids in one of these outcrops can be explained if the scaphite represents the early Coniacian form of $S$. corvensis. Furthermore, it is noteworthy that nacreous scaphites, assignable to $S$. corvensis and $S$. mariasensis Cobban, were found in clay ironstone concretions in the Carlile Shale at one locality along the Pembina River in northeastern North Dakota. These specimens, now in the Geology Department, University of North Dakota, Grand Forks, were collected by Wosick (1977), who recorded them as $S$. carlilensis Morrow in his thesis and gave their stratigraphic position as about 40 $\mathrm{m}$ below the top of the Carlile Shale.

The Minnesota specimen is in the Department of Geology and Geophysics, University of Minnesota, Minneapolis. The specimen was originally referred to $S$. impendicostatus Cobban of early Coniacian age (Sloan, 1964, p. 27).

Type.-Hypotype UMIP 8284.

\section{Scaphites mariasensis Cobban}

1951. Scaphites mariasensis Cobban, U.S. Geological Survey Profes(1952) sional Paper 239, p. 28, pl. 8, figs. 14-17.

This species occurs in two forms, a large inflated form and a small slender one. The large one was described as the typical form, and the small one was given the name S. mariasensis var. gracillistriatus Cobban (1951, p. 28, pl. 8, figs. 7-13). According to present-day systematics, the large inflated form would be interpreted as a female, and the other, a male (Cobban, 1969, p. 7-13).

Scaphites mariasensis is characterized by high, narrow, sharp ribs. Primary ribs are abundant and flexuous on the body chamber, where they number 15 on the holotype. The type came from the basal part of the Kevin Member of the Marias River Shale in northcentral Montana, where it was associated with $S$. preventricosus Cobban, Inoceramus waltersdorfensis Andert, and I. erectus Meek, of early Coniacian age.

Most of an adult scaphite that very closely resembles the holotype of $S$. mariasensis was discovered by Wosick (1977) in a unit of clay ironstone concretions in the Carlile Shale on the Pembina River. The locality is 5.8 $\mathrm{km}$ east-northeast of Vang, Cavalier County, N. Dak. Other fossils from this site include scaphites referable to $S$. corvensis Cobban. These specimens are at the Geology Department, University of North Dakota, Grand Forks.

\section{Scaphites preventricosus Cobban \\ Plate 8 , figures $11-13$}

1951. Scaphites preventricosus Cobban, U.S. Geological Survey (1952) Professional Paper 239, p. 26, pl. 9, figs. 1-16.

Like Scaphites mariasensis Cobban, S. preventricosus consists of a large inflated form (female) and a smaller and more slender form (male) that was described as $S$. preventricosus var. sweetgrassensis Cobban (1951, p. 27, pl. 10, figs. 18-25). The holotype (female) of the species is a complete adult $75 \mathrm{~mm}$ long and $39.5 \mathrm{~mm}$ thick with 10 primary ribs and 45 secondary ones on the body chamber. The species differs from $S$. mariasensis in having lower ribs and, on the body chamber, fewer primaries.

The holotype of $S$. preventricosus came from the lower part of the Kevin Member of the Marias River Shale in north-central Montana (early Coniacian age). Associated fossils include $S$. impendicostatus Cobban, Baculites mariasensis Cobban, and Cremnoceramus deformis (Meek).

An excellent specimen of $S$. preventricosus was found in glacial drift on a farm $1.6 \mathrm{~km}$ north of Ghent, Lyon County, Minn. The preservation indicates that the specimen came from a septarian limestone concretion. This scaphite, which closely resembles the holotype of $S$. preventricosus, is $84 \mathrm{~mm}$ long, $43 \mathrm{~mm}$ thick, and has 9 primary ribs and 43 secondary ones on the body chamber. The specimen was presented by Phyllis Regnier to the Department of Geology and Geophysics, University of Minnesota, Minneapolis.

Type.-Hypotype UMIP 9007. 
Genus OTOSCAPHITES Wright, 1953

Otoscaphites seabeensis Cobban and Gryc

Plate 5, figures 6-11, 16, 17

1961. Otoscaphites seabeensis Cobban and Gryc, Journal of Paleontology, v. 35 , no. 1, p. 184, pl. 38, figs. 13-27; text fig. $2 \mathrm{~d}, \mathrm{e}, \mathrm{n}$.

Small size, depressed section of body chamber, very broad venter, and angular tuberculate ventrolateral shoulder are important features of this species. The holotype and paratypes are from the Seabee Formation at outcrops on the north slope of Alaska.

Several scaphites, referable to Otoscaphites seabeensis, were collected from a hard concretionary limestone that rests on Precambrian granite in the Dakota Granite Company's quarry east of Milbank, in the SW $1 / 4$ sec. 18 , T. 120 N., R. 47 W., Grant County, S. Dak. (USGS D10415). Some individuals (pl. 5, figs. 9-11) have rib densities comparable to those listed by Cobban and Gryc (1961, table 3), but others are either more finely ribbed (pl. 5, figs. 16, 17) or more coarsely ribbed (pl. 5, figs. 6-8).

The specimens from near Milbank were associated with Scaphites delicatulus sloani and other mollusks from the subzone of Collignoniceras woollgari regulare (middle Turonian age).

Types.-Hypotypes USNM 299151-299154. Family ENGONOCERATIDAE Hyatt, 1900
GenuS METENGONOCERAS Hyatt, 1903

Metengonoceras dumbli (Cragin)

Plate 6 ; plate 7 , figure 8 ; plate 8 , figures 5,6

1893. Sphenodiscus dumbli Cragin, Geological Survey of Texas 4th Ann. Rept., p. 243, pl. 44, fig. 6.

For synonymy, see Cobban and Scott, 1972, U.S. Geological Survey Professional Paper 645, p. 59.

This very involute, compressed species has a smooth shell except for sinuous growth lines. The venter is very narrowly truncated almost to the aperture of large adults, where the venter becomes narrowly rounded. Very closely spaced septa are characteristic (pl. 7, fig. 8). Lobes are abundant, short, and little divided; saddles are broad, shallow, and usually undivided.

Cragin's types came from the Eagle Ford Shale of Texas. The suture of only one specimen was illustrated (Cragin, 1893, pl. 44, fig. 6). According to Stephenson (1952, p. 207), only one of Cragin's types has been located. Stephenson (1952, pl. 55) illustrated this specimen as well as a large adult from the Templeton Member of the Woodbine Formation of northern Texas. At several localities in Texas, Metengonoceras dumbli was associated with ammonites identified by
Stephenson as Acanthoceras tarrantense (Adkins), A. tarrantense nitidum Stephenson, $A$. wintoni Adkins, and $A$. adkinsi Stephenson, all of middle Cenomanian age. Inasmuch as the Eagle Ford specimens are from the "Metoicoceras whitei zone" (Stephenson, 1952, p. 207) at the top of the Cenomanian, Metengonoceras dumbli has a considerable range.

A fragment of $M$. dumbli from the Mesabi Range was first identified as Placenticeras (Sphenodiscus) sp. undet. by C. A. White (in Winchell, 1893, p. 221). Later, Bergquist (1944, p. 8, 30) suggested that this fossil was Epengonoceras cf. dumblei (sic), and reported that small fragments of it occurred in the Coleraine Formation at Calumet and Coleraine, Minn. Specimens of $M$. dumbli from the Mesabi Range are few and fragmentary. The largest fragment available is part of an adult body chamber, preserved as iron carbonate, which has a whorl height of $94 \mathrm{~mm}$. This specimen was presented to the late James P. Conlin, Fort Worth, Texas, by Blaine Conley, Swan River, Minn. Another of Conley's specimens shows the characteristic simple suture and is illustrated on plate 8 , figures 5 and 6 .

Metengonoceras dumbli has been collected from the basal part of the Graneros Shale at Riverside, Iowa, and from the Coleraine Formation in the western part of the Mesabi Range in northern Minnesota (USGS 13063). The better specimens are from the claypits at Riverside, and two large but crushed individuals are at the Sioux City Public Museum. Both are adults that have much of the body chamber preserved. The larger one (pl. 7, fig. 8) shows the sutures well and closely resembles the large specimen from the Woodbine Formation figured by Stephenson (1952, pl. 55, figs. 2, 3). The other specimen (pl. 6) is on a slab of shaly siltstone with the inner whorls of Dunveganoceras pondi Haas. Several other fragments of $M$. dumbli from Riverside are in the collections at the Peabody Museum of Natural History.

Types.-Hypotypes USNM 299174; SCPM F259C, F259D.

\section{Family PLACENTICERATIDAE Hyatt, 1900 GenuS PROPLACENTICERAS Spath, 1926 \\ Proplacenticeras pseudoplacenta (Hyatt) \\ Plate 7 , figures $3-5$}

1893. Placenticeras placenta (DeKay)? Stanton, U.S. Geological (1894) Survey Bulletin 106, p. 169, pl. 39, fig. 1 only.

1903. Placenticeras pseudoplacenta Hyatt, U.S. Geological Survey Monograph 44, p. 216, pl. 43, figs. 3-11; pl. 44.

Hyatt defined this species chiefly from the details of its fairly simple suture. Reeside (1927, p. 8) summarized the features of the shell noting that the flanks were flattened in juveniles and very broadly rounded in adults 
and that the shell was either smooth or had inconspicuous nodes and ribs. Two of Hyatt's four illustrated specimens came from the Tropic Shale in upper Kanab valley, Kane County, southwestern Utah, and the others came from the Carlile Shale in Colorado and the Pierre Shale in South Dakota. Inasmuch as the holotype was not selected, a specimen from the Tropic Shale that shows many of the features of the species is herein designated as the lectotype (Hyatt, 1903, pl. 43, figs. 3-6).

Proplacenticeras pseudoplacenta is represented by seven specimens from the concretionary limestone at the base of the Cretaceous in the Dakota Granite Company's quarry east of Milbank, in the SW $1 / 4$ sec. 18 , T. 120 N., R. 47 W., Grant County, S. Dak. (USGS D10415). Tubercles are absent, and the flanks are either smooth or have very weak falcoid ribs on the outer half. The specimens are not large, and none has a whorl height exceeding $68 \mathrm{~mm}$. Associated fossils include Collignoniceras woollgari regulare (Haas) of middle Turonian age.

The lectotype of $P$. pseudoplacenta and the holotype of $P$. stantoni are probably from the same locality and same part of the Tropic Shale. The specimens of $P$. pseudoplacenta from the Dakota Granite Company's quarry were associated with a single specimen of $P$. stantoni. Proplacenticeras pseudoplacenta and P. stantoni are possibly smooth and ornamented forms of the same species. Larger collections are needed to evaluate their similarities.

Winchell $(1895$, p. 53) recorded Placenticeras placenta (DeKay) from $11 \mathrm{~m}$ below the surface in a well near Marshall, Lyon County, Minn. This specimen, in the collections of the University of Minnesota, Minneapolis (UMIP 2282), is from a clay ironstone concretion and retains some of the nacreous shell material. The specimen consists of part of the crushed phragmocone and the older part of the body chamber that has a whorl height of $60 \mathrm{~mm}$ at its base. Suture complexity is only moderate, like that of specimens of $P$. pseudoplacenta. The specimen probably came from the noncalcareous part of the Carlile Shale.

Types.-Hypotypes USNM 299169, 299170.

Proplacenticeras stantoni (Hyatt)

Plate 7, figures 1,2

1893. Placenticeras placenta (DeKay)? Stanton, U.S. Geological (1894) Survey Bull. 106, p. 169, pl. 39, figs. 2, 3 (not fig. 1).

1903. Placenticeras stantoni Hyatt, U.S. Geological Survey Monograph 44, p. 214.

The holotype of Proplacenticeras stantoni is an internal mold of a phragmocone from the Tropic Shale of the upper Kanab valley in Kane County, southwestern
Utah. Nodate umbilical tubercles and clavate ventrolateral tubercles are conspicuous. The flanks are smooth except for very weak falcoid ribs on the outer half. Neither Stanton nor Hyatt illustrated the suture. The specimen probably came from the highly fossiliferous limestone concretions in the lower part of the Tropic Shale (Stanton, 1893, p. 35) which have the Sciponoceras gracile (Shumard) fauna of latest Cenomanian age.

A phragmocone from the concretionary limestone at the base of the Cretaceous in the Dakota Granite Company's quarry east of Milbank, in the SW1/4 sec. 18, T. 102 N., R. 47 W., S. Dak (USGS D10415), seems assignable to $P$. stantoni. The specimen is a little stouter than the holotype, and the ribbing is more pronounced. Associated fossils include Collignoniceras woollgari regulare (Haas).

Type.-Hypotype USNM 299168.

Family ACANTHOCERATIDAE de Grossouvre, 1894 Genus DUNVEGANOCERAS Warren and Stelck, 1940

Dunveganoceras pondi Haas

Plate 6; plate 9; plate 10, figure 1; plate 15, figure 1; text figure 2

1949. Dunveganoceras pondi Haas, Bulletin of the American Museum of Natural History, v. 93, art. 1, p. 22, pl. 8, figs. 15, 8; pl. 9, figs. 1, 3, 4; pls. 10-14; text figs. 11-13, 16, 1 .

1979. Dunveganoceras pondi Haas. Merewether, Cobban, and Cavanaugh, The Mountain Geologist, v. 16, no. 3, pl. 4.

Dunveganoceras pondi, of late Cenomanian age, differs from other species of the genus in having ribs on the adult body chamber that are depressed in the middle of the venter. The inner whorls are like those of the other species in having bullate umbilical tubercles, nodate or clavate inner ventrolateral tubercles and clavate outer ventrolateral tubercles. On the last whorl of the phragmocone, the location of the umbilical bullae gradually shifts, with growth, to the flank, and near the end of the phragmocone, the ventrolateral tubercles merge into blunt horns. The ribs on the body chamber are straight and rectiradiate, and, toward the aperture, they become flange like and replace the horns. These ribs are well rounded and much narrower than the interspaces. The ribs slope toward the venter, which gives the whorl section (fig. 2) a trapezoidal appearance. Dunveganoceras pondi has a typical acanthoceratid suture (pl. 9). The first lateral saddle is broad and bifid, and the lateral lobe is moderately broad, rectangular, and bifid.

A few specimens of $D$. pondi have been found in ferruginous siltstone concretions in the basal part of the Graneros Shale in the claypits at Riverside, Iowa. A very good adult specimen is on display at the Sioux City Public Museum (pl. 9). Most of the body chamber of an 


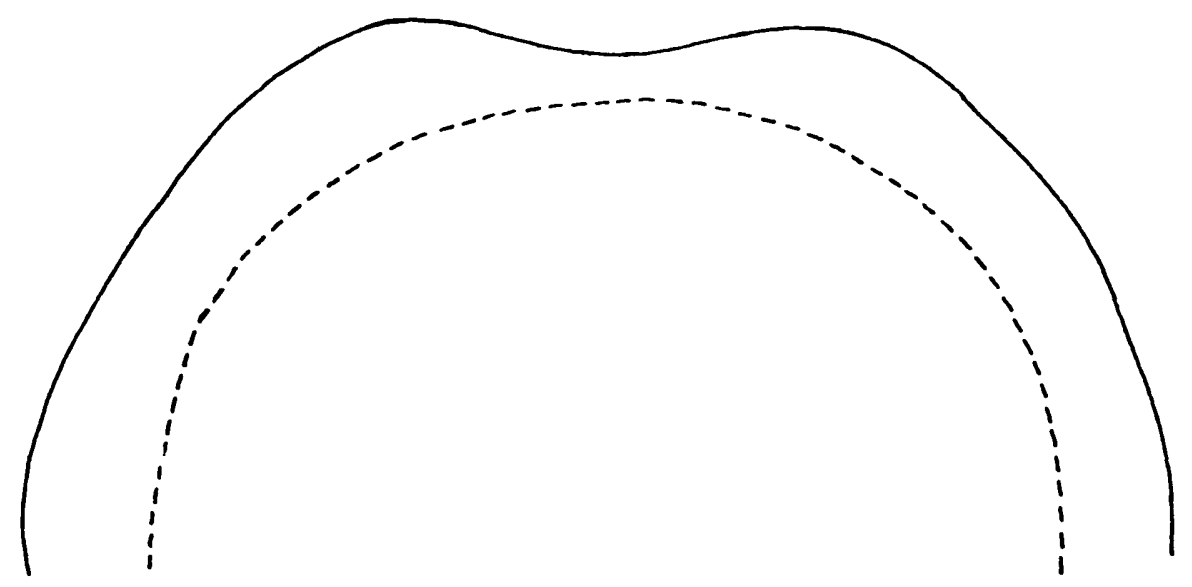

Figure 2.-Part of whorl section, natural size, of Dunveganoceras pondi Haas (see this report, pl. 10, fig. 1), from the basal part of the Graneros Shale at the Sioux City Brick and Tile Company's claypit, Riverside, Iowa. Hypotype YPM 14897. Dashed line is intercostal section.

adult is in the collections of the Peabody Museum of Natural History at Yale University, New Haven, Conn. (pl. 10, fig. 1). Part of a septate inner whorl was found as float at a roadcut in the Graneros Shale $14 \mathrm{~km}$ northeast of Sioux City, Iowa (USGS D10412; pl. 15, fig. 1). All specimens were associated with Inoceramus prefragilis stephensoni Kauffman and Powell, and those from Riverside were also with Metengonoceras dumbli (Cragin). The ammonite referred to as Prionocyclus sp. by Bain (1896, p. 274) from a claypit at Riverside is probably $D$. pondi.

Type.-Hypotypes YPM 14897; USNM 299183; SCPM F259C.

\section{Dunveganoceras hagei Warren and Stelck}

Plate 10, figure 2; plate 11; plate 12, figures 6,7 ; text figures 3,4

1944. Metacalycoceras? sp. Bergquist, Journal of Paleontology, v. 18, no. 1, p. 29.

1944. Acanthoceras? sp. Bergquist, Journal of Paleontology, v. 18, no. 1, p. 29.

1951. Dunveganoceras cf. pondi Haas. Haas, American Museum Novitates No. 1490 , p. 2 , fig. 1.

1955. Dunveganoceras hagei Warren and Stelck, Research Council of Alberta Report No. 70, p. 69, pl. 5, fig. 1.

Dunveganoceras hagei, of late Cenomanian age, is represented by many fragments at the Department of Geology and Geophysics, University of Minnesota, Minneapolis, and by a large nearly complete specimen at the Department of Geology, University of Minnesota, Duluth. All are from the Coleraine Formation of the western part of the Mesabi Range, Itasca County.
The holotype of $D$. hagei came from Dunvegan Creek, southwest of Dunvegan, in the Peace River area of western Alberta, Canada. The specimen, $260 \mathrm{~mm}$ in diameter, is most of an adult that has one-half of a whorl of the body chamber preserved. The umbilicus has a diameter of $90 \mathrm{~mm}$ (umbilical ratio $=0.35$ ). Ribs are straight, rectiradiate to prorsiradiate, and number 19 on the last whorl. Inner and outer rows of ventrolateral tubercles persist to the older part of the body chamber, where the inner row gradually disappears. The outer row continues on the rest of the preserved part of the body chamber and borders a slightly flattened venter.

Fragments of Dunveganoceras at the University of Minnesota, Minneapolis, seem assignable to $D$. hagei. One of the larger fragments, an internal mold of ferruginous sandstone, is shown on plate 12 . This specimen, the older one-third of an adult body chamber, closely matches in size and ornamentation the older part of the body chamber of the holotype. The whorl section (fig. 3) is like that described by Warren and Stelck (1955, p. 69) for the older part of the body chamber. The Minnesota specimen was described by Bergquist (1944, p. 29) as Acanthoceras sp.

The nearly complete specimen at the University of Minnesota, Duluth, was described by Haas (1951, p. 2, fig. 1) as Dunveganoceras $\mathrm{cf}$. pondi Haas. This specimen (pl. 10, fig. 2; pl. 11; text fig. 3), an internal mold of very hematitic sandstone, is slightly crushed. Haas reported its diameter as about $378 \mathrm{~mm}$ and its umbilical ratio as 0.345 . Only traces of sutures are visible, and the base of the body chamber is not easily determined. Haas believed that the last septum was at a diameter of about $300 \mathrm{~mm}$, which may be correct. Ribs, which number 20 


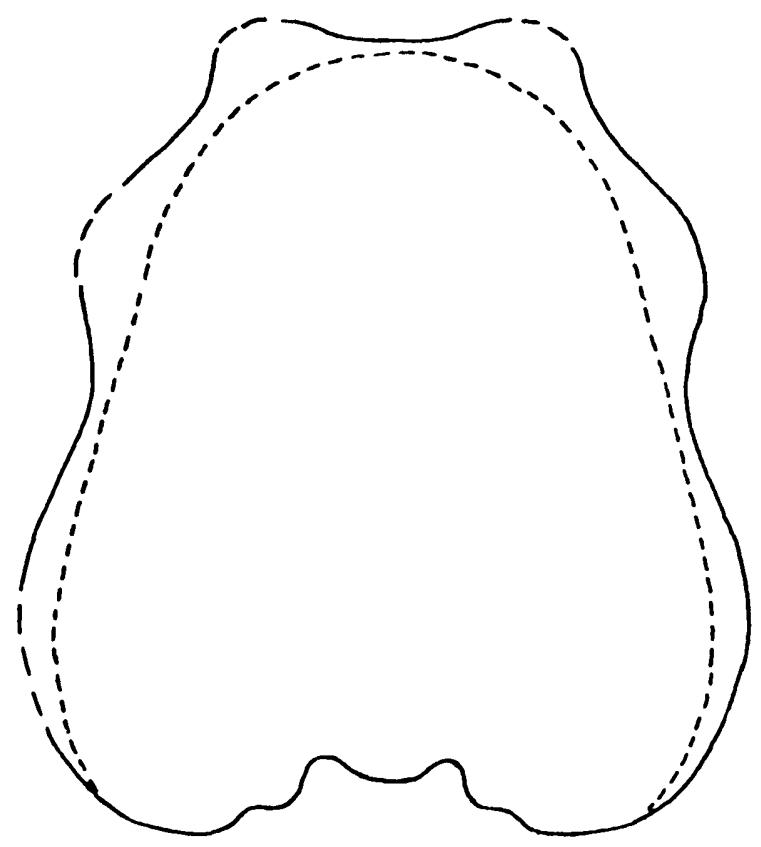

FIGURE 3.-Whorl section, natural size, of Dunveganoceras hagei Warren and Stelck (see this report, pl. 12, figs. 6, 7), from the Coleraine Formation at the Hill Annex mine, Calumet, Minn. UMIP 5058. Inner dashed line is intercostal section.

on the last whorl, are straight, rectiradiate, narrowly rounded, and narrower than the interspaces. All ribs begin at the umbilical shoulder and cross the entire flank. No secondary ribs are visible. Inner and outer ventrolateral tubercles are present on the penultimate whorl and on the first part of the outer whorl. As the outer whorl enlarges, the inner row of ventrolateral tubercles disappears, and the outer row borders the flattened venter for a short distance before merging with the ribs, which become high and almost pointed on crossing the venter. The cross section of the body chamber of this specimen is a pointed arch (fig. 4) like that of the holotype of $D$. albertense (Warren, 1930b, pl. 1, fig. 2). Such a section is not present on the extant part of the body chamber of the holotype of $D$. hagei, although Warren and Stelck (1955, p. 69) observed a change in the whorl section at the last preserved rib to that of "a trapezoidal outline with the ventral region slightly depressed." Quite likely, the whorl section of the succeeding ribs would be a pointed arch.

Haas (1951, f.g. 1) showed only a lateral view of the Duluth specimen. The opposite side (pl. 11) is visible in an illustration in Geotimes (1963, p. 14) that concerns geologic exhibits at the University of Minnesota, Duluth.

Types.-Hypotype UMIP 5058; Univ. Minn., Duluth, unnumbered.
Genus METOICOCERAS Hyatt, 1903

Metoicoceras bergquisti Cobban, $n$. sp.

Plate 8 , figures $1-4$; plate 12 , figures $1-5$; plate 13 ; plate 14 , figures $1-5,10-15$

1944. Metoicoceras aff. M. swallovi (Shumard). Bergquist, Journal of Paleontology, v. 18 , no. 1 , p. 30 , pl. 10 , figs. 10-12.

Metoicoceras is present as internal molds of ferruginous siltstone in the basal part of the late Cenomanian Coleraine Formation in the Mesabi Range in northern Minnesota. Of the 15 specimens available, 11 represent a smooth to weakly ribbed stout form that has a flat to very broadly rounded smooth venter. The other

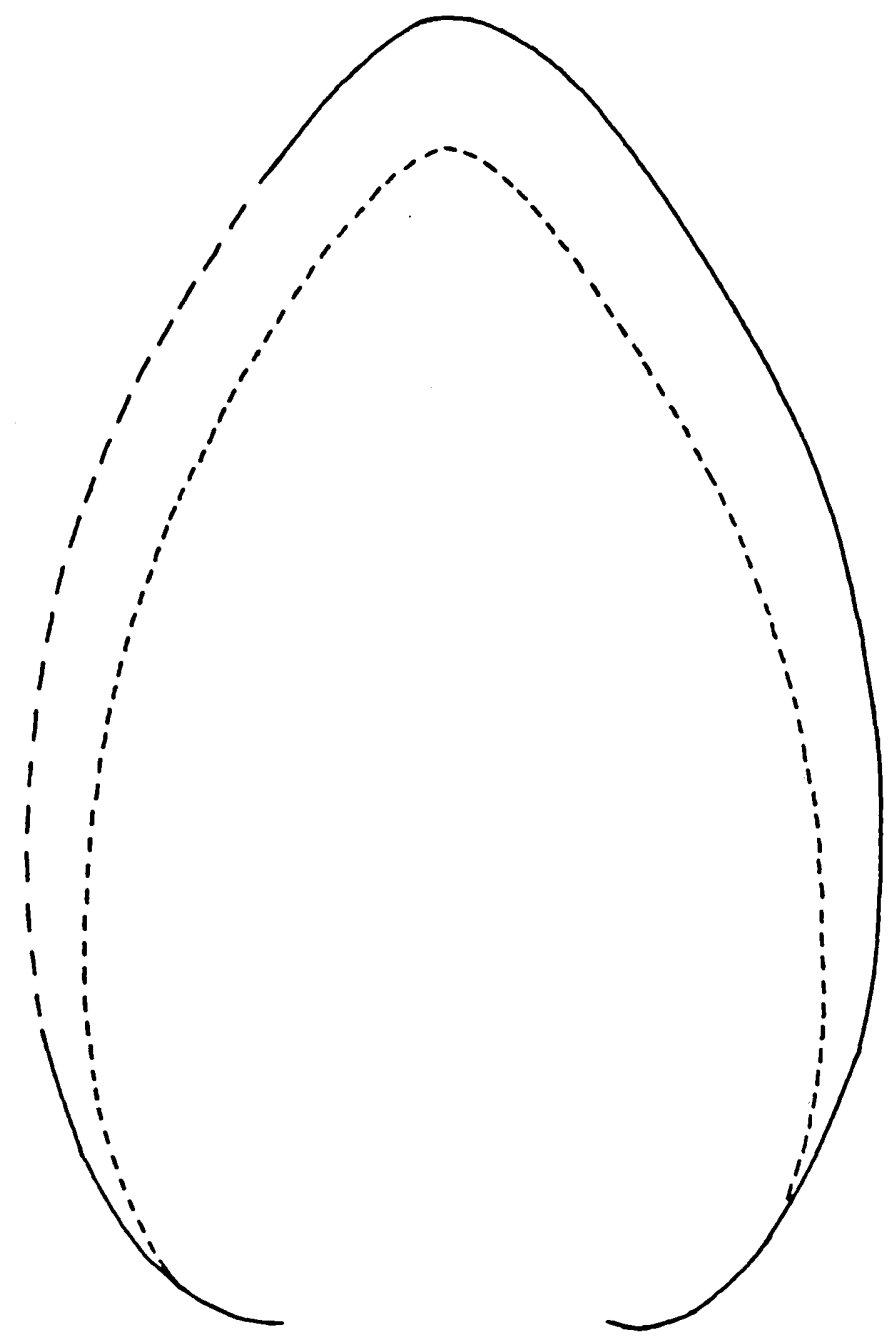

FIGURE 4.-Whorl section, natural size, of the body chamber of Dunveganoceras hagei Warren and Stelck (see this report, pl. 10, fig. 2; pl. 11), from the Coleraine Formation at the Hill Annex mine, Calumet, Minn. Inner dashed line is intercostal section. 
specimens have stronger ornamentation. Bergquist (1944, pl. 10, figs. 10-12) illustrated a single specimen of each form. Inasmuch as the two forms occur together, I believe they represent a single species.

The more ornamented form (pl. 12, figs. 1-3) has prorsiradiate ribs that are highest and broadest on the outer part of the flank. The ribs are rounded and narrower than the interspaces, and number about 14 or 15 per onehalf whorl. Most begin on the inner part of the flank, but some arise at midflank. On the early whorls (Bergquist, 1944, pl. 10, fig. 12), the ribs have double ventrolateral tubercles, an inner row of nodate to bullate ones and an outer row of clavate ones. The inner tubercles weaken and disappear where the shell has a small diameter, but the outer ones may persist until the diameter is as much as $80 \mathrm{~mm}$.

The smoother form consists of fragments that (1) lack ornamentation (pl. 14, figs. 4, 5, 10, 11), (2) have smooth flanks and very weak outer clavate ventrolateral tubercles (pl. 14, figs. 1, 2), or (3) have very weakly ribbed flanks and no ventrolateral tubercles (pl. 8, figs. 3, 4; pl. 13). The innermost whorls are not preserved in the specimens studied. At the smallest diameter observed (about $20 \mathrm{~mm}$ ), the flanks are smooth and only weak clavate outer ventrolateral tubercles are present.

The holotype (pl. 14, figs. 1-3) is the older half of a small adult body chamber, which has a whorl height of $38 \mathrm{~mm}$ and a thickness of $24.5 \mathrm{~mm}$. The flanks are slightly rounded and smooth, and the smooth, flat venter is bordered by very weak outer clavate ventrolateral tubercles. A latex cast (pl. 14, fig. 3) of the last inner whorl displays weak ribs on the outer half of the flank. These ribs are slightly accentuated where inner ventrolateral tubercles should occur, and they terminate in well-defined outer ventrolateral clavi. About 15 ribs occur per half whorl.

External sutures are visible on several specimens (pl. 12 , figs. 1,5 ; pl. 14 , figs. $4,5,10,11$ ). These sutures, as well as those visible on the two specimens figured by Bergquist (1944, pl. 10, figs. 10-12), closely resemble the sutures of some specimens of Metoicoceras whitei, $M$. gibbosum, and $M$. kanabense illustrated by Hyatt (1903, pl. 13 , fig. 5 ; pl. 14 , figs. 3 , 8 ; pl. 15 , figs. $7,8,11$ ).

Metoicoceras bergquisti attained a large size. The largest specimen studied (pl. 13) consists of the younger part of a body chamber, which has a whorl height of about $96 \mathrm{~mm}$.

The ornamented form of $M$. bergquisti resembles $M$. gesliniatum (d'Orbigny), as interpreted by Juignet, Kennedy, and Wright (1973, p. 234-236), in having about the same rib density and in losing the inner ventrolateral tubercles at a small diameter; but the il- lustrated specimens of $M$. gesliniatum are more compressed and do not grade into a smooth form.

Types.-Holotype UMIP 9004; paratypes UMIP 5061, 6178, 9003, 9005a, 9005b, 9008; USNM 299173, 299182.

\author{
Genus WATINOCERAS Warren, 1930 \\ Watinoceras coloradoense (Henderson) \\ Plate 15, figure 12
}

1908. Acanthoceras coloradoensis Henderson, U.S. National Museum Proceedings, v. 34, no. 1611, p. 259, pl. 13, figs. 10, 11 .

1972. Watinoceras coloradoense (Henderson). Cobban and Scott, U.S. Geological Survey Professional Paper 645, p. 76, pl. 27, figs. $11-19$; pl. 28 , figs. $1-3,5-9$; text figs. $35-37$.

A single poorly preserved specimen from the Greenhorn Formation at Lake Traverse, Minn. (USGS D10578), seems assignable to Watinoceras coloradoense. The specimen, about $55 \mathrm{~mm}$ in diameter, is an internal mold in a piece of hard gray limestone. Ribs are preserved on part of the last whorl and on the next to the last of the inner whorls. The ribs are straight and slightly prorsiradiate. They number 20 per half whorl at a whorl diameter of about $18.5 \mathrm{~mm}$, and about 14 at a diameter of $55 \mathrm{~mm}$. Cobban and Scott (1972, p. 76) noted that specimens from Pueblo, Colo., have 15-20 ribs per half whorl at diameters of from 10 to $30 \mathrm{~mm}$, and $10-13$ ribs at diameters of from 50 to $60 \mathrm{~mm}$. On the ribbed inner whorl, every other rib begins at the umbilicus much like some of the ribs on one of the small specimens illustrated by Cobban and Scott (1972, pl. 28, fig. 2). On the outer whorl, every other rib (primary) begins from a bullate umbilical tubercle, and all ribs have inner and outer ventrolateral tubercles. The outer ones are clavate, but the inner ones are too damaged to reveal their shape.

The specimen was found as float on the Greenhorn Formation. At Pueblo, Colo., W. coloradoense is known only from one bed of limestone at the top of the lower one-third of the Bridge Creek Limestone Member of the Greenhorn Formation (Cobban and Scott, 1972, p. 76). Other fossils found in this bed at Pueblo include Mytiloides aff. M. duplicostatus (Anderson), Puebloites spiralis Cobban and Scott, Ampakabites collignoni Cobban and Scott, Vascoceras (Greenhornoceras) birchbyi Cobban and Scott, Fagesia sp., Neoptychites xetriformis Pervinquière, and $N$. cephalotus (Courtiller). This is very definitely an early Turonian assemblage.

Type.-Hypotype USNM 299190. Collected by Jayne Sieverding and Sheila Stenzel, east shore of Lake Traverse, in the NE $1 / 4 \mathrm{SE}^{1 / 4}$ sec. 2, T. 125 N., R. 49 W., Traverse County, Minn. 
Family COLLIGNONICERATIDAE Wright and Wright, 1951 Genus COLLIGNONICERAS Breistroffer, 1947

Collignoniceras woollgari regulare (Haas)

Plate 15 , figures $2-4,7-11$

1876. Prionocyclus (Prionotropis) woollgari (Manetll). Meek, U.S. Geological Survey of the Territories (Hayden) Report 9, p. 455, pl. 6, fig. 2; pl. 7, figs, 1-3.

1946. Prionotropis woollgari (Mantell) and varieties. Haas, Bulletin of the American Museum of Natural History, v. 86, art. 4, p. 150 , pls. 11,12 ; pl. 13 , figs. 1-3, 5-18 (not figs. 4, 19); pl. 14, figs. 1-10, 12-16 (not fig. 11); pl. 15, figs. 1-6, 9, 10 (not figs. 7,8 ; ; pls. 16, 17; pl. 18, figs. 1, 2, 7-9; pl. 24, fig. 1; text figs. $1-4,6-44,46-91$.

The cotypes of Collignoniceras woollgari woollgari, from the Middle Chalk of England, were described by Mantell (1822, p. 197, pl. 21, fig. 16; pl. 22, fig. 7) as Ammonites woollgari. Wright and Wright (1951, p. 35) designated the larger specimen as the lectotype. This specimen, an adult, is moderately evolute and ornamented by prorsiradiate, widely separated, straight ribs that have, on the inner whorls, bullate umbilical tubercles, nodate inner ventrolateral tubercles, and clavate outer ventrolateral tubercles. A clavate siphonal tubercle accompanies each rib. On the body chamber, the umbilical tubercles migrate outwards from the umbilicus with growth and merge into the ribs, and the ventrolateral tubercles fuse into conspicuous horns. Secondary ribs develop on the outer part of the last whorl, and each is represented by a low clavate siphonal tubercle. Opposite ventrolateral horns on the body chamber are joined by a pair of low ribs that bear siphonal clavi.

Most of the ammonites from the Carlile Shale of the Great Plains region that have been referred to C. woollgari differ from the lectotype in lacking secondary ribs on the outer whorl and in lacking the looped ribs connecting opposite ventrolateral horns. Haas (1946, p. 151-196), and later Matsumoto (1965, p. 12-15), documented great intraspecific variation within local populations of the American form. Haas named several forms as varieties including the varieties intermedia and regularis, which are in the middle of the range in variation. Cobban and Hook (1979, p. 6) determined that the common American form of $C$. woollgari was a little younger than the European form. Because of this difference in age, as well as differences in the ornamentation of the adult ammonites, Cobban and Hook considered the American form as a chronologic subspecies of the European $C$. woollgari. The name $C$. woollgari regulare (Haas) was applied to this late form of the species.

Collignoniceras woollgari regulare has been well illustrated by Meek (1876), Haas (1946), Matsumoto (1965), and Cobban and Hook (1979). Of the many specimens illustrated by Haas, however, three are not this subspecies. Two of the specimens (Haas, 1946, pl. 13 , figs. 4,19 , pl. 15 , figs. 7,8 , text figs. 5,45 ), from the Blue Hill Member of the Carlile Shale of Kansas, are Prionocyclus hyatti (Stanton); and the third (Haas, 1946, pl. 14, fig. 11) is Plesiacanthoceras wyomingense (Reagan) from the Belle Fourche Shale.

Typical specimens of $C$. woollgari regulare occur in a hard bed of gray limestone that rests unconformably on Precambrian granite in the Dakota Granite Company's quarry east of Milbank in the SW $1 / 4$ sec. 18, T. 120 N., R. 47 W., Grant County, S. Dak. (USGS D10415). Associated cephalopods include Baculites yokoyamai Tokunaga and Shimizu (pl. 14, figs. 6-8), Scaphites delicatulus sloani Cobban, n. subsp. (pl. 5, figs. 12-15, 18-23), Tragodesmoceras carlilense Cobban (pl. 5, figs. 4, 5), Proplacenticeras pseudoplacenta (Hyatt) (pl. 7, figs. 3-5), P. stantoni (Hyatt) (pl. 7, figs. 1, 2), Binneyites carlilensis Cobban (pl. 5, figs. 1-3), and Actinocamax sp. (pl. 7, figs. 6, 7). Darton (1905, p. 129, 131, 135; 1909, p. 49, 52) had earlier recorded "Prionotropis woolgari" from shallow water wells in the Milbank area.

Collignoniceras woollgari regulare was probably collected far east of Milbank. Kloos (1872, p. 23) collected impressions of ammonites in shale from a well dug about $3 \mathrm{~km}$ south of Richmond in the Sauk River valley in south-central Minnesota. These specimens were sent to F. B. Meek, who reported Ammonites percarinatus Hall and Meek and Scaphites larvaeformis Meek and Hayden. Ammonites percarinatus (Hall and Meek, 1856, p. 396, pl. 4, figs. $2 \mathrm{a}, \mathrm{b}$ ) was regarded as a synonym of "Prionocyclus (Prionotropis) woolgari" by Meek (1876, p. 455). Scaphites larvaeformis is a common associate of C. woollgari regulare in the Black Hills area of South Dakota and Wyoming.

Impressions of $C$. woollgari regulare are present in the cores from the Iowa Geological Survey-U.S. Geological Survey test hole $9-\mathrm{D}$ in the $\mathrm{NE}^{1 / 4} \mathrm{NE}^{1 / 4}$ sec. $5, \mathrm{~T} .95 \mathrm{~N}$., R. $47 \mathrm{~W}$., Sioux County, Iowa. The impressions, all juvenile ammonites, occur in calcareous shale $4.6-12.8 \mathrm{~m}$ above the base of the Carlile Shale.

White (1873a, p. 188; 1873b, p. 67) may have seen specimens of $C$. woollgari regulare obtained from the glacial drift in northeastern Iowa. Among fossils from the "bluish clay of the unaltered drift" near Lime Springs in Howard County, White recorded Belemnitella and Ammonites ("2 species"). The first is probably $A c$ tinocamax, and the latter may have included C. woollgari regulare inasmuch as a little later Meek (1876, p. 457) noted that White had seen "Prionocyclus (Prionotropis) woollgari" in the drift of northern Iowa.

A badly distorted specimen in a limestone concretion from the glacial drift in southwestern Minnesota may be C. woollgari regulare. This specimen, which is in the col- 
lections at the University of Minnesota, Minneapolis (UMIP 8898), came from the NE $1 / 4$ sec. 32 , T. 115 N., R. 38 W., Yellow Medicine County.

Ammonites that are probably $C$. woollgari regulare have been found in the glacial drift as far east as Illinois. Worthen (1890, p. 4, fig. 5) illustrated part of a whorl (pl. 15 , fig. 11) that has the narrow, widely spaced, prorsiradiate ribs typical of $C$. woollgari. The specimen was found in the "blue clays of the drift at Golden Bluff Vineyards, about two miles south of Warsaw." Other illustrated fossils from this locality include part of a belemnite guard (Worthen, 1890, p. 4, fig. 4) that resembles Actinocamax manitobensis (Whiteaves), a species that is widely distributed with C. woollgari regulare in the lower part of the Carlile Shale in the northern and central Great Plains region.

Some reports of $C$. woollgari may be based on misidentifications of juvenile Subprionocyclus percarinatus (Hall and Meek). Todd (1908, p. 2) reported "Prionotropis woolgari" from the Carlile Shale in southeastern South Dakota and much farther northwest near Redfield (Todd, 1909, p. 4). Todd (1903, p. 3) also reported that "Prinotropis" (sic) was found southeast of Mitchell "at depth of several feet $1 \frac{1 / 2}{2}$ miles north of Elmspring" (probably in sec. 28, T. 101 N., R. 58 W., Hanson County, S. Dak.).

Types.-Hypotypes USNM 299184-299189.

Collignoniceras vermilionense (Meek and Hayden)

Plate 5, figures $38-42$

1860. Ammonites vermilionensis Meek and Hayden, Proceedings of the Academy of Natural Sciences of Philadelphia, v. 7, p. 177.

1876. Mortoniceras? vermilionense (Meek and Hayden). Meek, U.S. Geological Survey of the Territories (Hayden) Report 9, p. 450 , pl. 7, fig. 2a, b.

1893. Mortoniceras vermilionense (Meek and Hayden). Stanton, (1894) U.S. Geological Survey Bulletin 106, p. 180, pl. 44, fig. 1. 1898. Mortoniceras vermilionense (Meek and Hayden). Logan, Kansas University Geological Survey, v. 4, p. 472, pl. 104, fig. 1.

1927. Prionotropis vermilionensis (Meek and Hayden). Reeside, U.S. Geological Survey Professional Paper 150-A, p. 10.

The holotype (pl. 5, fig. 38), and only specimen described, came from a limestone concretion in the Carlile Shale on the Missouri River a few kilometers upstream (west-northwest) of the type locality (Volcano Hill, Nebr.) of Hall and Meek's Ammonites percarinatus. Meek and Hayden $(1860$, p. 177) reported that the holotype of $A$. vermilionensis had been collected at the mouth of Vermilion (now spelled Vermillion) River. The Carlile Shale formerly cropped out along the south bank of the Missouri River opposite the mouth of the Vermillion River (Condra, 1908, pl. 5, fig. B).

Meek and Hayden's description of the holotype is as follows (1860, p. 177):

Shell compressed discoidal; umbilicus large, very shallow, and showing about four-fifths of each inner whorl; volutions five or more, rather sharply carinated around the middle of the dorsum, and ornamented on each side by nearly straight, simple, moderately strong, obtuse costae, which show a tendency to develop nodes at each extremity. Greatest diameter 1.05 inches; convexity about 0.29 inch.

In addition to these observations, the holotype has an umbilical ratio of 0.44 and about 21 prorsiradiate, slightly flexuous ribs on the last whorl and 25 on the preceding whorl. The ribs are mostly of equal prominence, and most have umbilical bullae. Each rib rises into a nodose thickening at the ventrolateral shoulder and then bends forward onto the venter.

Specimens closely resembling the holotype occur sparsely in septarian limestone concretions in the Carlile Shale in southeastern South Dakota and northeastern Nebraska. Two specimens from Volcano Hill, Dixon County, Nebr. (USGS D10404), are shown on plate 5. One specimen (pl. 5, figs. 39, 40) has a diameter of 56 $\mathrm{mm}$, umbilical width of $25.5 \mathrm{~mm}$ (umbilical ratio $=0.45$ ), and rib counts per whorl of 28 at $14 \mathrm{~mm}$ diameter, 20 at $31 \mathrm{~mm}$, and 19 at $56 \mathrm{~mm}$. Ribs are slightly prorsiradiate and of equal strength. The ribs on the outer whorl have umbilical bullae and ventrolateral swellings. A conspicuous clavate tubercle is present on the keel for each rib. The other specimen (pl. 5, figs. 41, 42) has a diameter of $71.5 \mathrm{~mm}$, umbilical width of $31 \mathrm{~mm}$ (umbilical ratio $=0.43$ ), and rib counts per whorl of 30 at 16 $\mathrm{mm}$ diameter and 16 at $36 \mathrm{~mm}$ and $70 \mathrm{~mm}$ diameters. On this individual, the serrations on the keel are subdued. Ribs are straight, rectiradiate, and uniform in strength. The ribs on the last two whorls have umbilical bullae, and the ribs on the outer whorl have prominent ventrolateral nodes on the older part and ventrolateral horns on the younger part. The two illustrated specimens are probably small adults. Some other specimens attained much larger sizes. A phragmocone from a septarian limestone concretion in the Carlile Shale at Union County State Park, Union County, S. Dak. (USGS $\mathrm{D} 10410$ ), is $100 \mathrm{~mm}$ in diameter.

The suture of $C$. vermilionense, well illustrated by Meek (1876, pl. 7, fig. 2b), is moderately simple and has a very broad bifid first lateral saddle and narrow rectangular lateral lobe.

Collignoniceras vermilionense is associated with Subprionocyclus percarinatus (Hall and Meek) in the Carlile Shale (middle Turonian age) in southeastern South Dakota and northeastern Nebraska. Ammonites identified by Logan (1898, p. 473) as Mortoniceras ver- 
milionense from the "Fort Benton limestone" (Bridge Creek Member of the Greenhorn Formation) and "Septaria horizons" (Blue Hill Member of Carlile Shale) of Kansas represent other genera and species.

Types.-Holotype USNM 224; hypotypes USNM 299166, 299167.

\section{Genus SUBPRIONOCYCLUS Shimizu, 1932}

Subprionocyclus percarinatus (Hall and Meek)

Plate 5, figures 26-37

1856. Ammonites percarinatus Hall and Meek, American Academy of Arts and Sciences Memoirs, n. ser., v. 5, p. 396, pl. 4, fig. $2 a, b$.

1876. Prionocyclus (Prionotropis) woollgari (Mantell). Meek, U.S. Geological Survey of the Territories (Hayden) Report 9, p. $455,457$.

1893. Prionotropis woolgari (Mantell). Stanton, U.S. Geological (1894) Survey Bulletin 106, p. 174.

1946. Prionotropis woolgari Meek (? non Mantell). Haas, Bulletin of the American Museum of Natural History, v. 86, art. 4, p. $150,151,153$.

1952. Collignoniceras woolgari (Mantell). Stephenson, U.S. (1953) Geological Survey Professional Paper 242, pl. 12, fig. 3.

The type lot consists of small crushed specimens not exceeding $25 \mathrm{~mm}$ in diameter (Haas, 1946, p. 153). The specimens came from " *** Five miles below the mouth of Vermilion River on the Missouri; in division No. 2 of Section" (Hall and Meek, 1856, p. 396). In that area, the only outcrops are of the Carlile Shale and are on the northeast side of Volcano Hill near the center of sec. 3, T. 31 N., R. 5 E., Dixon County, Nebr. (USGS D10404). Specimens from this locality are comparable to the types and occur as sparse imprints in gray noncalcareous clayey shale (pl. 5, fig. 35) and, more rarely, as uncrushed specimens in gray septarian limestone concretions (pl. 5, figs. 26-33, 36, 37).

Subprionocyclus percarinatus is a compressed, densely ribbed, keeled ammonite ornamented by "thirty-eight to forty-five prominent flexuous sharp ribs some of which originate in the umbilicus, and others upon the latero-ventral margin, and all extend to the dorso-lateral edge, where they bend abruptly forward, and terminate before reaching the dorsal line, which is marked by a thin sharp carina extending to the aperture. Ribs thickened and sometimes nodose towards the periphery" (Hall and Meek, 1856, p. 396). Two specimens were illustrated by Hall and Meek, a very small specimen and a much larger one about $25 \mathrm{~mm}$ in diameter. The latter one is herein designated as the lectotype, and Hall and Meek's drawing of it is reproduced on plate 5 , figure 34 .

A limestone concretion from the type locality (USGS D10404) of $S$. percarinatus contained seven specimens suitable for measurements; six are shown on plate 5 , figures $26-33,36,37$. These specimens, from 12 to $32 \mathrm{~mm}$ in diameter, have umbilical ratios of $0.32-0.45$ and rib counts per one-half whorl of 18-25. The ribs are narrow and flexuous like those of the types, and every second or third one, or rarely every fourth or fifth, is higher and begins at the umbilicus. These higher ribs (primaries) have umbilical bullae. All ribs bend forward at the ventrolateral shoulder and disappear at the base of the keel. Two specimens have a double row of ventrolateral tubercles of equal strength, another has an inner row stronger than the outer, two have only outer ones, and the other two have none-although the ends of the ribs are slightly accentuated where the outer ventrolateral tubercles should be. The inner ventrolateral tubercles are nodate, and the outer ones are nodate or clavate. The keel is serrate, and each serration (clavate tubercle) corresponds to a rib. Sutures are clearly visible on only one individual, which has broad bifid first and second lateral saddles and a narrow, poorly divided lateral lobe.

Subprionocyclus percarinatus seems to be a small species. All seven specimens from the limestone concretion include parts of the body chambers. Diameters at the base of the body chamber range from 10 to $22 \mathrm{~mm}$.

Hall and Meek's Ammonites percarinatus seems best assigned to Subprionocyclus. Wright and Matsumoto (1954, p. 129) and later Matsumoto (1959, p. 108, 109) summarized Subprionocyclus noting that ribs are primary and secondary and usually flexuous, and that the inner ventrolateral tubercles may weaken on the outer whorls. Most specimens from the limestone concretions collected at Volcano Hill fit this description, although the single individual that has inner ventrolateral tubercles dominant over the outer ones suggests a link to Collignoniceras.

Hall and Meek (1856, p. 382, 383, 387, 388) described the new species Cytherea orbiculata, C. tenuis, Inoceramus conradi, and $I$. fragilis from the same locality that yielded the types of their Ammonites percarinatus. The small ammonites, identified as Collignoniceras woolgari (Mantell) by Stephenson (1952, pl. 12 , fig. 3), on the piece of gray shale that contains the holotype of I. fragilis, are Subprionocyclus percarinatus.

Impressions of small ammonites that seem to be $S$. percarinatus occur in outcrops of gray noncalcareous Carlile Shale in a stream cut along Brule Creek $\left(\mathrm{N}^{1 / 2} \mathrm{sec}\right.$. 32, T. 94 N., R. 50 W.), in Union County State Park in southeastern South Dakota. Specimens from this locality are in the collections of the Department of Earth Science and Physics, University of South Dakota, Vermillion. Similar impressions also occur in gray noncalcareous shale in an excavation southeast of Mitchell, in the $\mathrm{SE}^{1 / 4} \mathrm{NE}^{1 / 4}$ sec. 8, T. 102 N., R. 59 W., Hanson County, S. Dak. (USGS D10701), where the shale is distorted by glacial action and may be transported. Distorted shale of a different color (yellowish gray) at 
this locality contains impressions of Inoceramus prefragilis stephensoni Kauffman and Powell of late Cenomanian age.

Two small impressions of finely ribbed ammonites, which may be $S$. percarinatus, were found in noncalcareous clay shale in the lower part of the Carlile Shale, on the southeast bank of Lake Traverse, Minn. At this locality, in the $\mathrm{NE}^{1 / 4} \mathrm{SE}^{1 / 4}$ sec. 2, T. $125 \mathrm{~N}$., R. 47 W., Traverse County, the upper part of the Greenhorn Formation and some of the Carlile Shale crop out (Shurr, 1979). Much farther southeastward in Minnesota, impressions of similar small ammonites were found in noncalcareous gray shale from $3 \mathrm{~m}$ below the surface, at a stock pond excavation in the $\mathrm{SE}^{1 / 4}$ sec. 16 , T. 110 N., R. 39 W., Redwood County. These specimens are in the collections at the University of Minnesota, Minneapolis.

The Cretaceous seaway during the time of $S$. percarinatus may have covered much of Minnesota. A clay ironstone concretion found in the glacial drift south of Minneapolis contained an ammonite that may be $S$. percarinatus (pl. 15, figs. 5, 6).

Specimens identified as Ammonites percarinatus were recorded by Marcou (1867, p. 61, pl. 1) from the lower part of the Big Sioux River valley along the border of South Dakota and Iowa. According to the columnar section shown by Marcou (1867, pl. 1), the ammonites came from a unit of limestone containing "Inoceramus problematicus." This limestone unit is probably the upper part of the Greenhorn Formation, and the inoceramid is probably Mytiloides mytiloides (Mantell). The ammonites observed were probably juveniles of some other species, possibly Collignoniceras woollgari (Mantell). Impressions of small ammonites, recorded as Prionocyclus wyomingensis by Wilder (1900, p. 113), from the Carlile Shale of this area are probably Subprionocyclus percarinatus.

Hayden (1873, p. 53) reported "Ammonites peracutus" [S. percarinatus $]$ from the "Fort Benton" near the mouth of "Iowa Creek." The Dakota Formation, Graneros Shale, and Greenhorn Formation crop out near the mouth of Aowa Creek (formerly Iowa Creek) in eastern Dixon County, Nebr., and the ammonite reported by Hayden is probably some other species from the Graneros Shale.

Meek (1876, p. 455, 457) believed that Ammonites percarinatus Hall and Meek, 1856, was a synonym of $A$. woollgari Mantell, 1822, and that the correct name was Prionocyclus (Prionotropis) woollgari (misspelled woolgari). This conclusion was accepted by Stanton (1893, p. 174), and consequently, ammonites from the Carlile Shale of southeastern South Dakota and northeastern Nebraska were identified by Stanton as Prionocyclus woolgari (sic) (Todd, 1904, p. 571) or Prionotropis woolgari (sic) (Todd, 1908, p. 2). Meek
(1876, p. 457) noted earlier that C. A. White had found this ammonite in the glacial drift of northwestern Iowa.

The exact position of Subprionocyclus percarinatus in the ammonite zonation of the Western Interior cannot be determined from collections of fossils from southeastern South Dakota and northeastern Nebraska. However, on the south flank of the Black Hills in southwestern South Dakota and on the Chadron arch in northwestern Nebraska, $S$. percarinatus has been found in limestsone concretions in the Carlile Shale immediately above beds containing Collignoniceras woollgari regulare (Haas). The age of $S$. percarinatus is probably middle Turonian. Types.-Hypotypes USNM 299159-299165.

Genus PRIONOCYCLUS Meek, 1876

Prionocyclus novimexicanus (Marcou)

1858. Ammonites novi-mexicani Marcou, Geology of North America, p. 35 , pl. 1, figs. 2, 2a.

1946. Prionocyclus wyomingensis var. elegans Haas, American Museum of Natural History Bulletin, v. 86, art. 4, p. 200, pl. 19 , figs. $1-7$, 11-14; pl. 20 , fig. 4 ; pl. 21 , figs. $1-3,5$; pl. 22 , figs. 1, 2; text figs. 98-104.

1979. Prionocyclus novimexicanus (Marcou). Hook and Cobban, New Mexico Bureau of Mines and Mineral Resources Annual Report 1977-1978, p. 35, figs. 3E-L.

This ornate, fairly evolute, compressed ammonite has abundant prorsiradiate closely spaced flexuous ribs and a conspicuous serrate keel. Ribs are primary and secondary, and most primaries arise from umbilical bullae, cross the flank with sinuosity, and curve forward on the ventrolateral shoulder, where they rise into prominent clavate tubercles oriented about $45^{\circ}$ to the keel. Secondary ribs also curve forward on the ventrolateral shoulder, where some rise into low clavate tubercles that parallel the primary ones.

Prionocyclus novimexicanus is common in the middle part of the late Turonian Turner Sandy Member of the Carlile Shale in the Black Hills area of western South Dakota. The species has not been identified with certainty from outcrops east of the Black Hills. However, specimens have been found in the glacial drift in Minnesota. In 1926, a piece of a phragmocone was found in the Twin City Brick Company's pit in west St. Paul (USGS 13739). Recently, David Jones, Worthington, Minn., kindly showed me a very good specimen of $P$. novimexicanus in a septarian limestone concretion that was found in a streambed at Russell, Lyon County, by Timothy D. Holt of Marshall, Minn.

An ammonite listed as Prionocyclus wyomingensis Meek was recorded by Wilder (1900, p. 113) from the Carlile Shale south of Hawarden, in Sioux County in the northwestern part of Iowa. If that identification is correct, rocks nearly of the age of $P$. novimexicanus crop out along the Missouri River in the Sioux City area. 


\section{BELEMNITE \\ Family BELEMNITELLIDAE Pavlov, 1914 \\ Genus ACTINOCAMAX Miller, 1823 \\ Actinocamax sp.}

Plate 7, figures 6, 7

Fragments of belemnites that may be Actinocamax manitobensis (Whiteaves, 1889, p. 189, pl. 26, figs. 3, 3a, $3 \mathrm{~b})$ are locally abundant in the hard concretionary limestone that rests on Precambrian granite in the Dakota Granite Company's quarry east of Milbank, in the $\mathrm{SW} 1 / 4$ sec. 18 , T. 120 N., R. 47 W., Grant County, S. Dak. (USGS D10415). The fragments are associated with Collignoniceras woollgari regulare (Haas). In the northern part of the Western Interior of the United States, Actinocamax manitobensis has been found only in the zone of Collignoniceras woollgari in the basal part of the Carlile Shale and in the equivalent part of the Frontier Formation in central Wyoming (fig. 5). Belemnites have not been found in the rest of the Carlile Shale or in the underlying Greenhorn Formation.

The lectotype of $A$. manitobensis may be from glacial drift along the Assiniboine River valley in southern Manitoba, Canada (Jeletzky, 1950, p. 4). Other specimens, however, have been found in the Assiniboine Member of the Favel Formation at outcrops along the Assiniboine River near Treherne, Manitoba (fig. 5). Jeletzky (1950) described and illustrated many excellent specimens of $A$. manitobensis and its varieties from the Treherne area. Collignoniceras woollgari occurs in the upper part of the underlying Keld Member of the Favel Formation.

Belemnites, recorded as Belemnitella, have been found in the glacial drift in northeastern Iowa at Lime

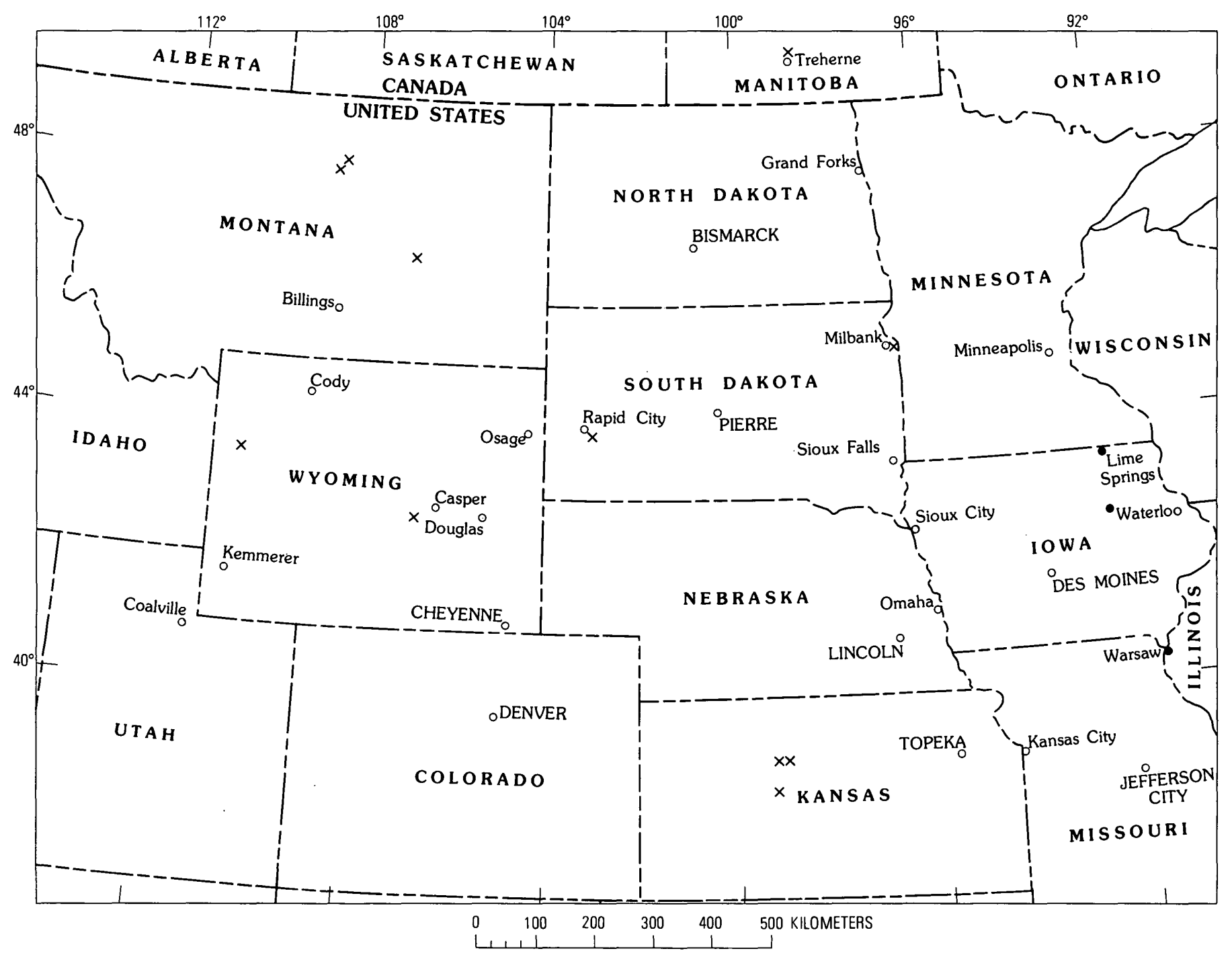

FIGURE 5.-Map of part of the Western Interior showing localities $(x)$ where Actinocamax manitobensis (Whiteaves) has been collected, and localities $(\bullet)$ where Actinocamax has been found in glacial drift. 
Springs, Howard County, and near Waterloo, Black Hawk County (White, 1873a, p. 188; 1873b, p. 67). A specimen was also found in the glacial drift farther southeast near Warsaw, Ill. (Worthen, 1890, p. 5 and text fig. 4 on p. 4). The Waterloo specimen was later identified as $A$. manitobensis by Jeletzky (1950, p. 21). The other specimens are probably Actinocamax, and quite likely $A$. manitobensis, inasmuch as this is the most common belemnite in the Western Interior.

Figured specimens.-USNM 299171, 299172.

\section{REFERENCES CITED}

Bain, H. F., 1896, Geology of Woodbury County: Iowa Geological Survey, v. 5, Annual Report 1895, p. 241-299.

Bergquist, H. R., 1944, Cretaceous of the Mesabi iron range, Minnesota: Journal of Paleontology, v. 18, no. 1, p. 1-30, pls. 1-11.

Bolin, E. J., 1956, Upper Cretaceous foraminifera, ostracoda, and radiolaria from Minnesota: Journal of Paleontology, v. 30, no. 2, p. 278-298.

Cobban, W. A., 1951 [1952], Scaphitoid cephalopods of the Colorado group: U.S. Geological Survey Professional Paper 239, 42 p., 21 pls.

1955, Some guide fossils from the Colorado shale and Telegraph Creek formation, northwestern Montana, in Billings Geological Society Guidebook 6th Annual Field Conference, Sweetgrass arch-Disturbed belt, Montana, 1955: p. 198-207, pls. 1-4.

1969, The Late Cretaceous ammonites Scaphites leei Reeside and Scaphites hippocrepis (DeKay) in the Western Interior of the United States: U.S. Geological Survey Professional Paper 619, 29 p., 5 pls.

Cobban, W. A., Erdmann, C. E., Lemke, R. W., and Maughan, E. K., 1976, Type sections and stratigraphy of the members of the Blackleaf and Marias River Formations (Cretaceous) of the Sweetgrass arch, Montana: U.S. Geological Survey Professional Paper 974, 66 p., illus.

Cobban, W. A., and Gryc, George, 1961, Ammonites from the Seabee formation (Cretaceous) of northern Alaska: Journal of Paleontology, v. 35 , no. 1 , p. $176-190$, pls. 37,38 .

Cobban, W. A., and Hook, S. C., 1979 [1980], Collignoniceras woollgari woollgari (Mantell) ammonite fauna from Upper Cretaceous of Western Interior, United States: New Mexico Bureau of Mines and Mineral Resources Memoir 37, 51 p., 12 pls.

Cobban, W. A., and Scott, G. R., 1972, Stratigraphy and ammonite fauna of the Graneros Shale and Greenhorn Limestone near Pueblo, Colorado: U.S. Geological Survey Professional Paper 645,108 p., 41 pls.

Condra, G. E., 1908, Geology and water resources of a portion of the Missouri River in northeastern Nebraska: U.S. Geological Survey Water-Supply Paper 215, $59 \mathrm{p}$.

Conrad, T. A., 1860, Descriptions of new species of Cretaceous and Eocene fossils of Mississippi and Alabama: Academy of Natural Sciences of Philadelphia Journal, 2d ser., v. 4, p. 275-298.

Cragin, F. W., 1893, A contribution to the invertebrate paleontology of the Texas Cretaceous: Texas Geological Survey 4th Annual Report, pt. 2, p. 139-246, pls. 24-46.

Darton, N. H., 1905, Preliminary report on the geology and underground water resources of the central Great Plains: U.S. Geological Survey Professional Paper 32, 433 p. 1909, Geology and underground waters of South Dakota: U.S. Geological Survey Water-Supply Paper 227, $156 \mathrm{p}$.

Geotimes, 1963, U. of Minnesota, Duluth, unveils new geological exhibits: v. 7 , no. 7 , p. $14-15$.
Gill, J. R., and Cobban, W. A., 1965, Stratigraphy of the Pierre Shale, Valley City and Pembina Mountain areas, North Dakota: U.S. Geological Survey Professional Paper 392-A, 20 p.

Haas, Otto, 1946, Intraspecific variation in, and ontogeny of, Prionotropis woollgari and Prionocyclus wyomingensis: American Museum of Natural History Bulletin, v. 86, art. 4, p. 141-224, pls. 11-24.

1951, Supplementary notes on the ammonite genus Dunveganoceras: American Museum Novitates No. 1490, 21 p.

Hall, James, and Meek, F. B., 1856, Descriptions of new species of fossils from the Cretaceous formations of Nebraska, with observations upon Baculites ovatus and B. compressus, and the progressive development of the septa in Baculites, Ammonites, and Scaphites: American Academy of Arts and Science Memoir, new ser., v. 5 , p. $379-411$, pls. $1-8$.

Hattin, D. E., 1962, Stratigraphy of the Carlile Shale (Upper Cretaceous) in Kansas: Kansas Geological Survey Bulletin 156, 155 p., 27 pls.

1975, Stratigraphic study of the Carlile-Niobrara (Upper Cretaceous) unconformity in Kansas and northeastern Nebraska: Geological Association of Canada Special Paper 13, p. 195-210.

Hayden, F. V., 1873, First, second, and third annual reports of the United States Geological Survey of the Territories for the years 1867, 1868, and 1869 [Reprints]: $261 \mathrm{p}$.

Henderson, Junius, 1935, Fossil non-marine Mollusca of North America: Geological Society of America Special Papers No. 3, 313 p.

Hyatt, Alpheus, 1903, Pseudoceratites of the Cretaceous, edited by T. W. Stanton: U.S. Geological Survey Monograph 44, 351 p., 47 pls.

Jeletzky, J. A., 1950, Actinocamax from the Upper Cretaceous of Manitoba: Geological Survey of Canada Bulletin 15, p. 1-27, $36-41$, pls. $1-3$.

Juignet, Pierre, Kennedy, W. J., and Wright, C. W., 1973, La limite Cénomanien-Turonien dans la région du Mans (Sarthe); Stratigraphie et paléontologie: Annales de Paléontologie, v. 59, pt. 2, p. 209-242, 3 pls.

Kloos, J. H., 1872, A Cretaceous basin in the Sauk Valley, Minnesota: American Journal of Science, 3d ser., v. 3, p. 17-26.

Logan, W. N., 1898, The invertebrates of the Benton, Niobrara, and Fort Pierre Groups: Kansas University Geological Survey, v. 4, pt. 8, p. $431-518$, pls. $86-120$.

Mantell, Gideon, 1822, The fossils of the South Downs, or illustrations of the geology of Sussex: .London, Lupton Relfe, 327 p., 42 pls.

Marcou, Jules, 1867, Le terrain crétacé des environs de Sioux-City, de la Mission des Omahas et de Tekama, sur les bords du Missouri: Société Géologique de France Bulletin; 2d ser., v. 24, p., 56-71.

Matsumoto, Tatsuro, 1959, Upper Cretaceous ammonites of California, Part 2: Kyushu University, Memoirs of the Faculty of Science, Ser. D, Geology, Special Volume 1, 172 p., 41 pls. 1965, A monograph of the Collignoniceratidae from Hokkaido, Part 1: Kyushu University, Memoirs of the Faculty of Science, Series D, Geology, v. 16, no. 1, 80 p., 18 pls.

Meek, F. B., 1871, Preliminary paleontological report, consisting of lists of fossils, with descriptions of some new types, etc.: U.S. Geological Survey of Wyoming (Hayden), Preliminary Report [v. 4], p. 287-318.

1873, Preliminary paleontological report, consisting of lists and descriptions of fossils, with remarks on the ages of the rocks in which they were found, etc.: U.S. Geological Survey of the Territories (Hayden), Sixth Annual Report, p. 429-518.

1876, A report on the invertebrate Cretaceous and Tertiary fossils of the upper Missouri country: U.S. Geological Survey of the Territories (Hayden) Report 9, 629 p., 45 pls. 
Meek, F. B., and Hayden, F. V., 1857, Description of new Species and Genera of Fossils, collected by Dr. F. V. Hayden in Nebraska Territory, under the direction of Lieut. G. K. Warren, U.S. Topographical Engineer; with some remarks on the Tertiary and Cretaceous formations of the north-west, and the parallelism of the latter with those of other portions of the United States and Territories: Proceedings of the Academy of Natural Sciences of Philadelphia, v. 9, p. 117-148.

1860 , Descriptions of new organic remains from the Tertiary, Cretaceous and Jurassic rocks of Nebraska: Academy of Natural Sciences of Philadelphia Proceedings, v. 12, p. 175-185.

Miller, H. W., 1968, Invertebrate fauna and environment of deposition of the Niobrara Formation (Cretaceous) of Kansas: Fort Hays Studies, n. ser., Science Ser., no. 8, 90 p., 9 pls.

Moore, R. C., 1958, Introduction to historical geology (2d ed.): New York, McGraw-Hill, $656 \mathrm{p}$.

Morrow, A. L., 1935, Cephalopods from the Upper Cretaceous of Kansas: Journal of Paleontology, v. 9, no. 6, p. 463-473, pls. 49-53.

Morton, S. G., 1842, Description of some new species of organic remains of the Cretaceous group of the United States, with a tabular view of the fossils hitherto discovered in this formation: Academy of Natural Sciences of Philadelphia Journal, v. 8, p. 207-227, pls. 10, 11.

Pergament, M. A. 1966, Zonal'naia stratigrafiia i inotseramy nizhnei chasti verkhnego mela Tikhookeanskogo poberezh'ia SSSR [Zonal stratigraphy and inocerams of the lowermost Upper Cretaceous of the Pacific coast of the USSR]: Geological Institute of the Academy of Sciences of USSR Transactions, v. 146, 83 p., 36 pls.

Peterson, Fred, and Waldrop, H. A., 1965, Jurassic and Cretaceous stratigraphy of south-central Kaiparowits Plateau, Utah, in Geology and resources of south-central Utah-Resources for power: Utah Geological Society and Intermountain Association of Petroleum Geologists Guidebook to the geology of Utah, no. 19, p. $47-69$.

Reagan, A. B., 1924, Cretacic Mollusca of Pacific slope: Pan-American Geologist, v. 41, p. 179-190, pls. 18-21.

Reeside, J. B., Jr., 1927, Cephalopods from the lower part of the Cody shale of Oregon Basin, Wyoming: U.S. Geological Survey Professional Paper 150-A, p. 1-19, pls. 1-8.

Rodis, H. G., 1961, Availability of ground water in Lyon County, Minnesota: U.S. Geological Survey Circular 444, $7 \mathrm{p}$.

1963, Geology and occurrence of ground water in Lyon County, Minnesota: U.S. Geological Survey Water-Supply Paper 1619-N, $41 \mathrm{p}$.

Scott, G. R., and Cobban, W. A., 1964, Stratigraphy of the Niobrara Formation at Pueblo, Colorado: U.S. Geological Survey Professional Paper 454-L, p. L1-L30, 11 pls.

Shurr, G. W., 1979, Upper Cretaceous rocks at Lake Traverse in western Minnesota: U.S. Geological Survey Open-File Report 79-379.

Sloan, R. E., 1964, The Cretaceous System in Minnesota: Minnesota Geological Survey Report of Investigations 5, $64 \mathrm{p}$.

Stanton, T. W., 1893 [1894], The Colorado formation and its invertebrate fauna: U.S. Geological Survey Bulletin 106, 288 p., 45 pls.

Stauffer, C. R., and Thiel, G. A., 1941, The Paleozoic and related rocks of southeastern Minnesota: Minnesota Geological Survey Bulletin 29, $261 \mathrm{p}$.

Stephenson, L. W., 1952 [1953], Larger invertebrate fossils of the Woodbine formation (Cenomanian) of Texas: U.S. Geological Survey Professional Paper 242, p. 1-211, pls. 1-58.

Todd, J. E., 1903, Description of the Mitchell quadrangle [South Dakota]: U.S. Geological Survey Geologic Atlas, Folio 99, 7 p.
1904, Benton formation in eastern South Dakota: Geological Society of America Bulletin, v. 15, p. 569-575.

1908, Description of the Elk Point quadrangle, South Dakota-Nebraska-Iowa: U.S. Geological Survey Geologic Atlas, Folio 156, 8 p.

1909, Description of the Aberdeen-Redfield district [South Dakota]: U.S. Geological Survey Geologic Atlas, Folio 165, 13 p.

Upham, Warren, 1888, The geology of Crow Wing and Morrison Counties, in N. H. Winchell, The geology of Minnesota, v. 2, of the final report: Geological and Natural Survey of Minnesota, $p$. 580-611.

Warren, P. S., 1930a, New species of fossils from Smoky River and Dunvegan formations, Alberta: Research Council of Alberta Geological Survey Report 21, p. 57-68, pls. 3-7.

1930b, Three new ammonites from the Cretaceous of Alberta: Royal Society of Canada Transactions, 3d ser., v. 24, sec. 4, p. $21-26,4$ pls.

1947, Cretaceous Fossil Horizons in the Mackensie River Valley [Canada]: Journal of Paleontology, v. 21, no. 2, p. 118-123, pls. 29, 30.

Warren, P. S., and Stelck, C. R., 1955, New Cenomanian ammonites from Alberta: Research Council of Alberta Report No. 70, p. $63-75$, pls. $4-9$.

White, C. A., 1873a, On the eastern limit of Cretaceous deposits in Iowa: American Association for the Advancement of Science Proceedings, v. 21, p. 187-192.

$1873 \mathrm{~b}$, The eastern limit of Cretaceous deposits in Iowa: American Journal of Science, 3d ser., v. 5, no. 25, p. 66-69.

1883, A review of the non-marine fossil Mollusca of North America: U.S. Geological Survey Annual Report 3, p. 403-550, 28 pls.

1894, Notes on the invertebrate fauna of the Dakota formation, with descriptions of new molluscan forms: United States National Museum Proceedings, v. 17, no. 995, p. 131-138, pl. 8. Whiteaves, J. F., 1889, On some Cretaceous fossils from British Columbia, the Northwest Territory, and Manitoba: Geological Survey of Canada, Contributions to Canadian Palaeontology, v. 1, p. 151-196, pls. 20-26.

Whitfield, R. P., 1885, Brachiopoda and Lamellibranchiata of the Raritan clays and Greensand marls of New Jersey: U.S. Geological Survey Monograph 9, 251 p., 35 pls.

Wilder, F. A., 1900, Geology of Lyon and Sioux Counties: Iowa Geological Survey, v. 10, Annual Report 1899, p. 85-155.

Winchell, N. H., 1874, The geological and natural history survey of Minnesota; the second annual report for the year 1873, in University of Minnesota Annual Report for 1873: p. 73-219.

Winchell, H. V., 1893, Note on Cretaceous in northern Minnesota: The American Geologist, v. 12 , no. 4, p. 220-223.

1895, Other Cretaceous fossils in Minnesota in Minnesota Geological Survey Final Report, v. 3, pt. 1, p. 53, 54.

Woods, Henry, 1912, A monograph of the Cretaceous Lamellibranchia of England; v. 2, pt. 8: Palaeontographical Society Monograph, v. 65 , p. $285-340$, pls. 51-54.

Worthen, A. H., 1890, Drift deposits of Illinois: Geological Survey of Illinois, v. 8, p. 1-24.

Wosick, F. D., 1977, Stratigraphy and paleontology of the Upper Cretaceous Morden Member (Vermilion River Formation) in the outcrop area, northeastern North Dakota: North Dakota University Master's thesis, $152 \mathrm{p}$.

Wright, C. W., and Wright, E. V., 1951, A survey of the fossil Cephalopoda of the Chalk of Great Britain: Palaeontographical Society [Monograph], $40 \mathrm{p}$.

Wright, C. W., and Matsumoto, Tatsuro, 1954, Some doubtful Cretaceous ammonite genera from Japan and Saghalien: Kyushu University, Memoirs of the Faculty of Science, Series D, Geology, v. 4 , no. 2 , p. $107-134$, pls. 7,8 . 


\section{INDEX}

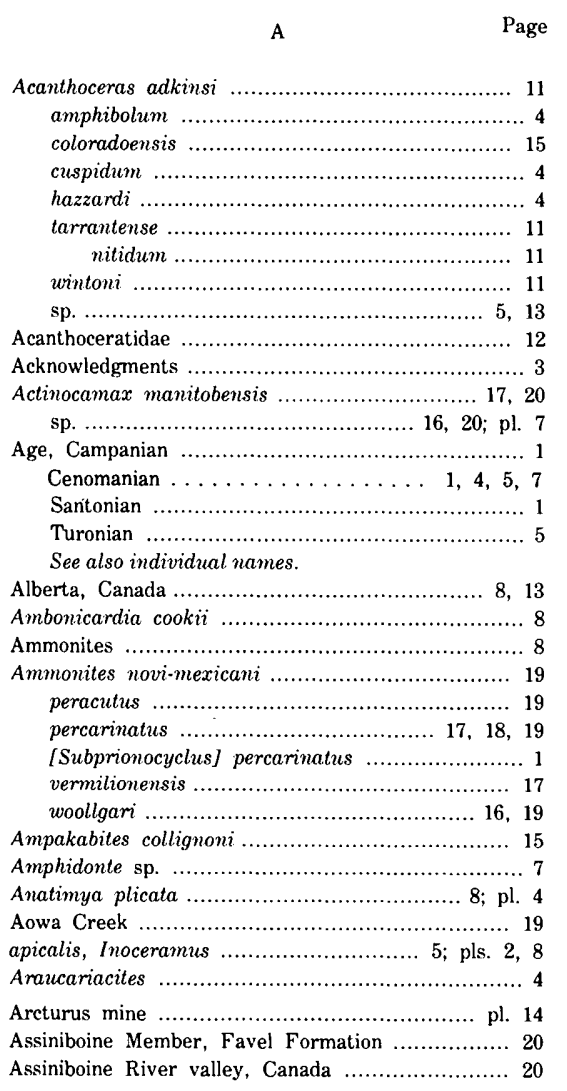

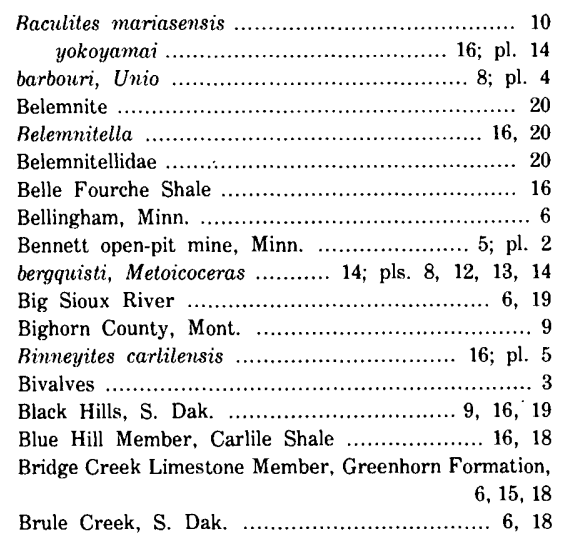

C

Page

Calumet, Minn

State Park, Minn. lile Shale $1,3,4,5,6,9,10,12,16,17,18$ basal

Blue Hill Member

lower

Turner Sandy Member

carlilense, Tragodesmocera

.

Dunveganoceras .................... 4,

early, Inoceramus .

Margaritifera ............................. 7 ; pl. 4

Plesiacanthoceras .................................... 4

middle, Metengonoceras

..... 11

Dunveganoceras ...................................... 12, 13

Inoceramus ..................................... 5, 1

Metoicoceras

Proplacenticeras .....1.

Scaphites .............................................. 9

Subprionocyclus ..................................... 19

Chadron arch, Subprionocyclus percarinatus ........ 19

Choffaticeras pavillieri ......................................

Coleraine, Minn., Metengonoceras dumbli ............. 11

Coleraine Formation ............................ 11, 13, 14 basal....

Collignoniceras vermilionense .................. 17; pl.

woollgari $\ldots \ldots, 18,19,20$ intermedia ....................................... 16 intermedia $5,12,16,19,20$, pl. 15 regularis

Collignoniceratidae 16

Colorado, southeastern, Volviceramus involutus ...... 7 coloradoense, Watinoceras ..................... 15; pl. 15 Coniacian, early

$$
\text { late }
$$

corvensis Scaphites ................... 9; pl. 5

Cremnoceramus, deformis . . . . . . . . . . 10

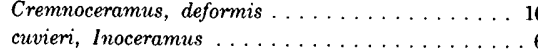

Cytherea orbiculata $\ldots \ldots \ldots \ldots \ldots \ldots \ldots \ldots$

tenuis .................. 18

D

Dakota City, Nebr.

Dakota Formation ................................ 1, 7, 8, 19 Dakota Granite Company quarry . 5, 9, 11, 12, 16, 20

Dakota Sandstone .....

Delano quarry, Minn. ...........................

delicatulus sloani, Scaphites ..................... $8 ; \mathrm{pl} .5$

Discinisca (Discaradisca) ......

dumbli, Metengonoceras ..........11; pls. $6,7,8$

Dunvegan, Canada .................. 13

Dunvegan Creek, Canada .............................. 13

Dunveganoceras hagei ................................. 13, pls. 10, 11, 12 pondi ............ 1, 3, 11, 12, 13; pls. $6,9,10,15$
E

Page

Eagle Ford Shale .............................................. 11 Elmspring, S. Dak. .......................................... 16

Engonoceratidae ............................................. 11

Epengonoceras dumblei ................................ 11

[Metengonoceras] dumbli ................................. 5

Equisetosporites ............................................... 4

Escalante, Utah ............................................... 6

\section{F}

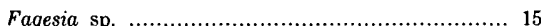

Fairbury, Nebr. ................................................ 8

Favel Formation, Assiniboine Member ................ 20

Keld Member

Foresteria (Texasia) dentatocarinatum ................... 9

Formations, Belle Fourche Shale ....................... 16 Carlile Shale ........ 1, 4, 5, 6, 9, 12, 16, 17, 18 basal ............................................ 20 Blue Hill Member ................................ 18

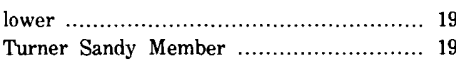
uppermost ........................................ 10

Cody Shale, Carlile Member ........................ 9 Coleraine ...................................... 5, 11, 13

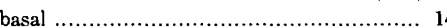

Dakota ................................. 1, 7, 8, 19

Eagle Ford Shale …............................. 11

Favel Formation ....................................... 20

"Fort Benton" .......................................... 19

Fox Hills ....................................................

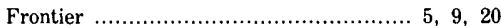

Graneros Shale ......................... 1, 3, 4, 5, 19 basal ...................................... 11, 12 Greenhorn ....................... 3, 4, 5, 6, 15, 19 Bridge Creek Member ......................... 18 upper part ......................................... 19

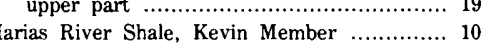
Middle Chalk .................................. 5, 6, 16 Niobrara …....................................... 1, 7

Smoky Hill Shale Member .....................

Pierre Shale ....................................... 1, 12

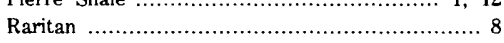

Seabee ................................................ 8

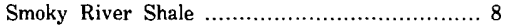

Straight Cliffs ........................................... 6

Tropic Shale ............................................ 12

Windrow .......................................... pl. 14

Woodbine ........................................... 4, 11

Templeton Member ............................ 11

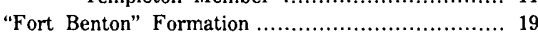

Fort Benton limestone ..................................... 18

Fox Hills Formation ..................................... 1

fragilis, Inoceramus .............................. 3; pl.

Frontier Formation .............................. 5, 9, 20

G

Ghent, Minn., Scaphites preventricosus ............... 10

ginterensis, Inoceramus ........................... 5; pl. 2 Golden Bluff Vineyards, Collignoniceras woollgari

regulare ........................................... 17 


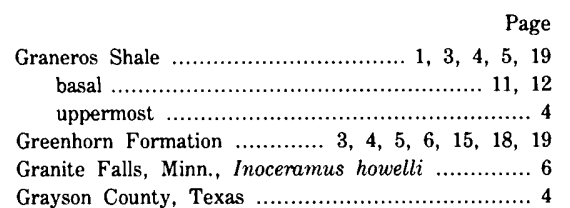

H

hagei, Dunveganoceras .......... 3, 13; pls. 10, 11, 12 Hartland Shale Member, Greenhorn Formation ....... 5 Hawarden, Iowa ….................................... 19 Hill Annex mine ...2. howelli, Inoceramus ................................... 6; pl.

\section{I}

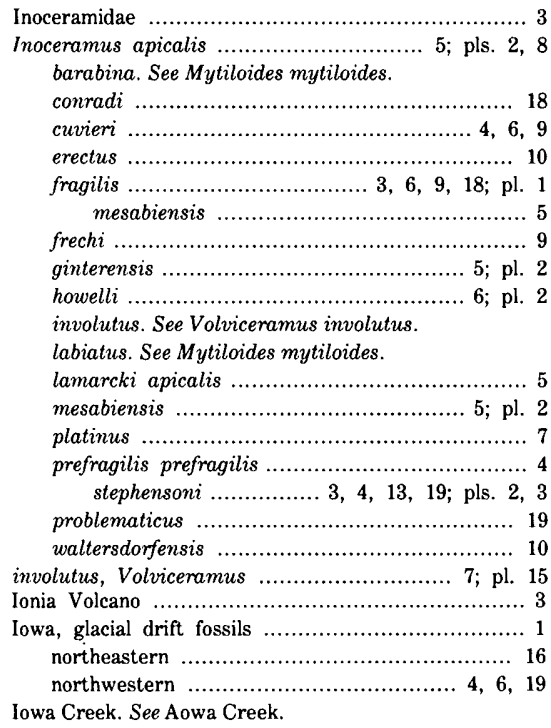

\section{K, L}

Kamchatka, U.S.S.R. .................................. 5

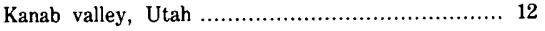
Keewatin, Minn. Keld Member, Favel Formation ……................... 20

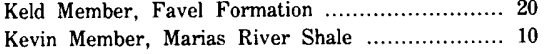

labiatus, Mytiloides .. pl. 8 Lake Traverse, Minn. .............................. 6, 15, 19 Laternulidae ................................................. 8 Lewisville Member, Woodbine Formation ................ 4 Lime Springs, Iowa .................................. 16, 20 Lincoln Limestone Member, Greenhorn Formation .. 4 Lower Potatoe Valley ....................................... 6

\section{M}

Mackenzie River, Canada, Scaphites delicatulus ..... 8 Mammites bellsanus, synonym ........................... 4 nodosoides

Manitoba, Canada

manitomensis Actinocamax

Margaritana .................................................... 7

Margaritifera nebrascensis ..................... 7, 8; pl. 4

Margaritiferidae …......................................... 7

Marias River Shale ........................................ 10

mariasensis, Scaphites ...................................... 10

Marshall, Minn., Proplacenticeras pseudoplacenta . 12

Mesabi Range ......................... 1, 3, 5, 11, 13, 14

mesabiensis, Inoceramus ........................ 5; pl. 2

Metacalyoceras sp. ............................. 5, 13

Metengonoceras dumbli ...... $3,4,11,13$; pls. 6, 7, 8
Page

Metoicoceras bergquisti 5,14 ; pls, $8,12,13,14$ crassicostae $\ldots .14$ gesliniatum

gibbosum .......

kanabense

latoventer

swallovi

white $i$

Middle Chalk, England

Milbank, S. Dak.

Minneapolis, Minn

Minnesota, glacial drift fossils .......................... 1, 3

Missouri River ........................ 1, 6, 17, 18, 19

Mitchell, S. Dak.

4,18

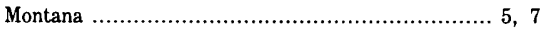

Mortoniceras vermilionense .................................. 17

Mytiloides s.1. .......................................... $6 ;$ pl. 1 duplicostatus '............................................ 15

labiatus ........................................

mytiloides .............................. 6, 19; pls. 1, 8

mytiloides, Mytiloides ...................... 6, 19; pls. 1,8

\section{$\mathrm{N}, \mathrm{O}$}

nebrascensis, Margaritifera 7 ; pl. 4

Nebraska, northeastern

$4,6,7$

Neoptychites cephalotus xetriformis .....

Niobrara Formation

North Dakota, eastern

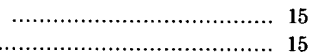

astern ................................ 1, 7

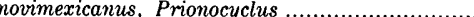

Ochs Brick and Tile Company claypit, Minn... pl. 14 Odessa, Minn., Mytiloides mytiloides ...

Ortonville, Minn., Mytiloides mytiloides

Ostrea sp.

patulus, Scaphites ............................... 9; pl. 1 Peace River, Canada, Scaphites delicatulus ........... 8 Pectunculus [Sanoarca] siouxensis ....................... 1 Pembina River, N. Dak. .................................. 10 percarinatus, Ammonites [Subprionocyclus] ............. 1 Subprionocyclus ................ 1, 18; pls. 1, 5, 15 Pierre Shale ....................................... 1, 12

Placenticeras placenta ............. (Sphenodiscus) sp. undet. .............................. 11

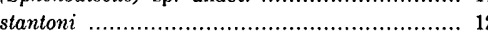
Placenticeratidae ............................................ 11 platinus Platyceramus ................................... 1, 7 plicata, Anatimya ................................. 8; pl. 4 Platyceramus platinus ..................................... 1, 7 Plesiacanthoceras wyomingense ....................... 4, 16 Plymouth County, Iowa ..................................... 4 Pollen, bisaccate conifer ............................. 4 Ponca State Park, Nebr. ............................... 4 pondi, Dunveganoceras ......... 1, 12; pls. 6, 9, 10, 15 Powder River basin

prefragilis prefragilis, Inoceramus

prefragilis stephensoni, Inoceram preventricosus, Scaphites ......................... 10; pl. 8 Prionocyclus .....

hyatti ....................

novimexicanus ...................................... 19

(Prionotropis) woolgari .................................. 18

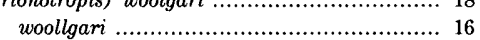
quadratus ............................................. 9 woolgari ................................................... 19

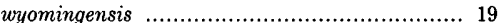
elegans ............................................. 19 sp. .................................................... 13 Prionotropis vermilionensis ............................ 17

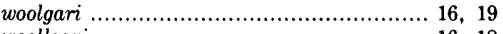
woollgar ..................................... 16, 18
Page

Proplacenticeras pseudoplacaenta ........... 11, 16; pl. stantoni $\ldots \ldots \ldots \ldots .12,16 ; \mathrm{pl} .7$ Pseudoperna congesta ......................................... 7 pseudoplacenta, Proplacenticeras .................. 11; pl. 7 Pterospermopsis ................................................. 4

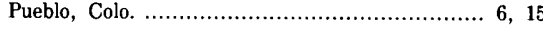

Puebloites ......................................................

R

Raritan Formation ...................................... 8

Redfield, S. Dak., Prionotropis woolgari ............. 17

Redwood County, Minn. .................................... 19

References cited ............................................... 21

regulare, Collignoniceras woollgari ............. 16; pl. 15

Richmond, S. Dak. ..................................... 16

Riverside, Iowa, claypit .......................... 4, 11, 12

Russell, Minn. .......................................... 9, 9

\section{S}

Sage Breaks Member, Carlile Shale ................... 10

St. James, Nebr., Volviceramus involutus .............

St. Paul, Minn. .......................................... 19

Sakhalin, U.S.S.R., Inoceramus ginterensis ............. 5

Sanoarca siouxensis ............................... 1; pl. 14

Santonian age ..................................... 1, 7

Sauk River valley .............................................. 16

Scaphites carlilensis ................................................ 10

corvensis ...................................... 9; pl. 5

delicatulus greenhormensis ........................... 9 sloani ........................... 8, 11, 16; pl. 15 impendicostatus ............................................ 10 mariasensis ................................................. 10 gracillistriatus .................................... 10

nigricollensis ................................................. 9

patulus ... 9; pl. 1

preventricosus ............................ 9, 10; pl. 8 sweetgrassensis .................................... 10

ventricosus zone .............................................. 7 Scaphitidae

Schizosporis reticulatus ........................................... 4

Sciponoceras gracile .................................. 9, 12

Seabee Formation ........................................... 8

seabeensis, Otoscaphites ............................ 11; pl. 5

Seaway, Cretaceous …......................................... 1

Shark teeth

Sioux City, Iowa $13,13,19$

Sioux City Brick and Tile Company claypit, Inoceramus

Sioux Quartzite prefragilis stephensoni ......................4

Sioux River....

siouxensis, Sanoarca ............. $1 ;$ pl. 14

Pectunculus [Sanoarca] .................................. 1 sloani, Scaphites delicatulus .................................. pl. 5 Smoky Hill Shale Member, Niobrara Formation . 7, 8 South Dakota, southeastern ................. 1, 6, 7,19 Sphenodiscus dumbli ......................................... 11 Spores, trilete ..................................................... 4 stantoni, Proplacenticeras ...................................... 12 stephensoni, Inoceramus prefragilis .................... 4 Straight Cliffs Formation ... Subprionocyclus percarinatus ........ 1, 3, 5, 9, 17, 18; sweetgrassensis, Scaphites preventricosus pls. 1, 5, 15

$$
\mathrm{T}
$$

Taxodiaceaepollenites .......................................... 4 Templeton Member, Woodbine Formation ......... 4, 11 Tetracolpites ................................................... 4 Tragodesmoceras carlilense ............................... 16 Treherne, Manitoba, Actinocamax manitobensis ... 20 Tricolpites ...

Tropic Shale ..................... Tropic Shaler Sandy Member, Carlile Shale ..................... 19 


\section{INDEX}

Page

Turonian age early

$3,5,6$

middle

upper

17,19

Twin City Brick Company

Two River, Minn.

7,8

$\mathrm{U}, \mathrm{V}$

Unio, (Baphia) nebrascensis

$$
\text { barbouri }
$$

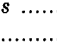

Unionidae ................................................ 8

Upper Chalk, England, Volviceramus involutus .... ?

Vang, S. Dak., Scaphites mariasensis

10

Vascoceras (Greenhornoceras) birchbyi

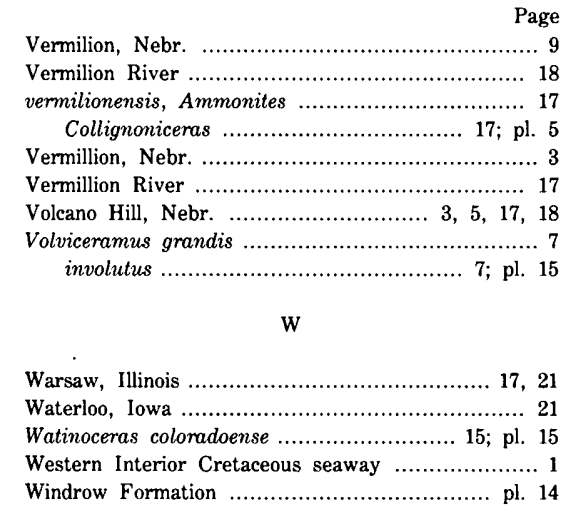

(1)

Woodbine Formation ..................................... 11 woollgari regulare, Collignoniceras ................................ 11 Wyoming, central, Frontier Formation ............ 9, 20

$$
\mathrm{Y}, \mathrm{Z}
$$

Yellow Medicine County Museum

Yellow Medicine River

yokoyamai, Baculites ................................ 16; pl. 14

Zone, Collignoniceras woollgari .......................... 20 Dunveganoceras albertense ......................... 5

Prionocyclus hyatti .

Pronocyclus hyatti ......................................... 7

Sciponoceras gracile Range ............................... 9

sub, Collignoniceras woollgari regulore .......... 11 



\section{PLATES 1-15}

Contact photographs of the plates in this report are available, at cost, from the U.S. Geological Survey Photographic Library, Federal Center, Denver, Colorado 80225. 


\section{PLATE 1}

[Figure 1 natural size; figure 2 slightly reduced]

\section{Turonian mollusks}

FIGURE 1. Mytiloides mytiloides (Mantell) s. l. (p. 6).

Latex cast of a slab of limestone from the Greenhorn Formation at USGS locality D10502 in the SE $1 / 4 \mathrm{NW}^{1 / 4}$ sec. 11, T. 31 N., R. 5 E., Dixon County, Nebr. USNM 299137.

2. Inoceramus fragilis Hall and Meek (p. 3).

Several specimens (a) in part of a limestone concretion from the Carlile Shale at USGS locality 2989 in sec. 29, T. 32 N., R. 4 E., Dixon County, Nebr. Other fossils are (b) Scaphites patulus Cobban and (c) Subprionocyclus percarinatus (Hall and Meek). USNM 299138. 
GEOLOGICAL SURVEY

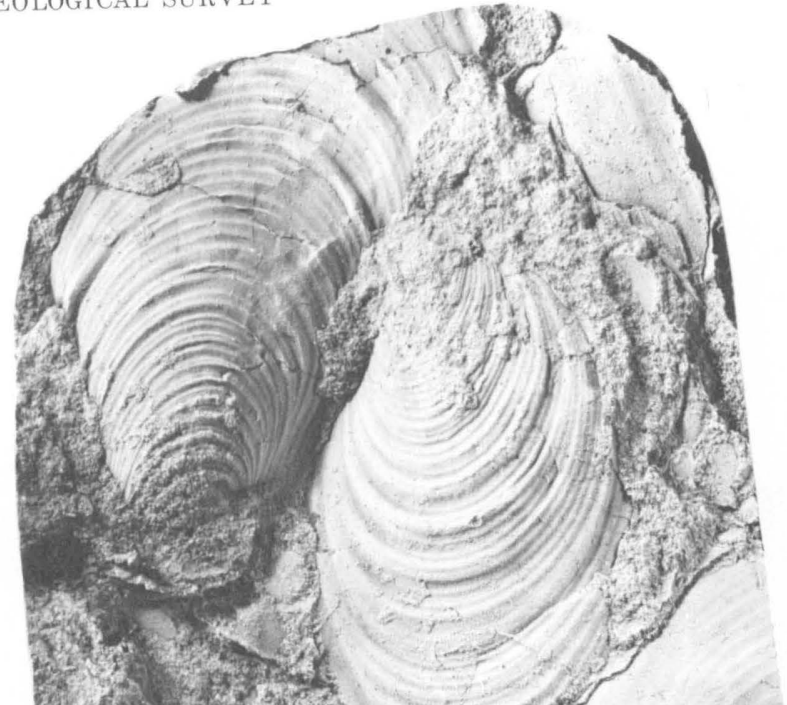

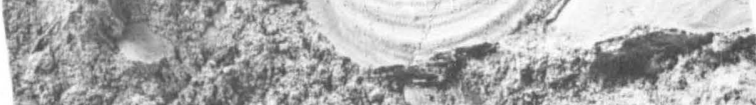

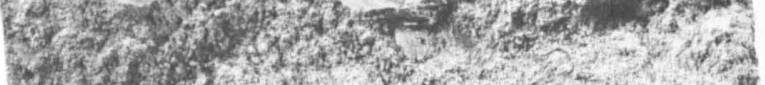
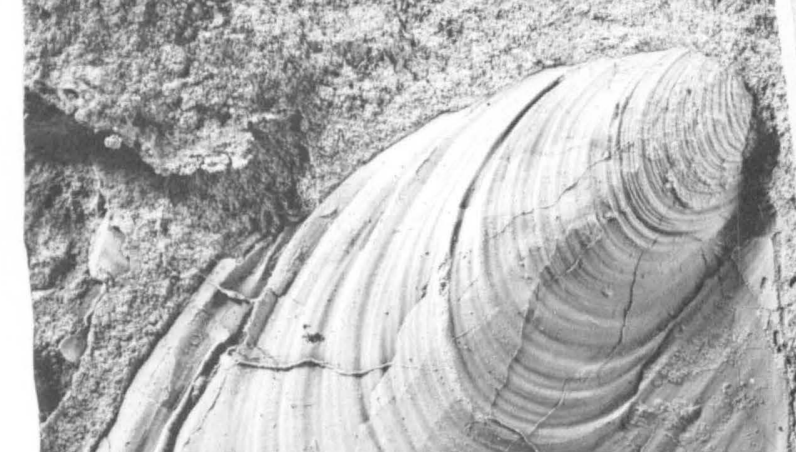

1

1.
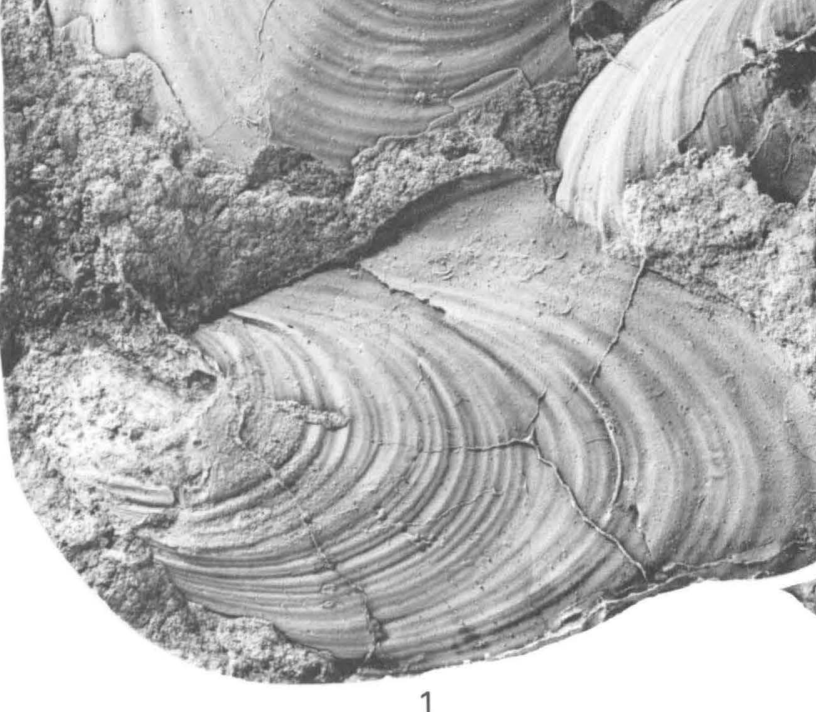

1

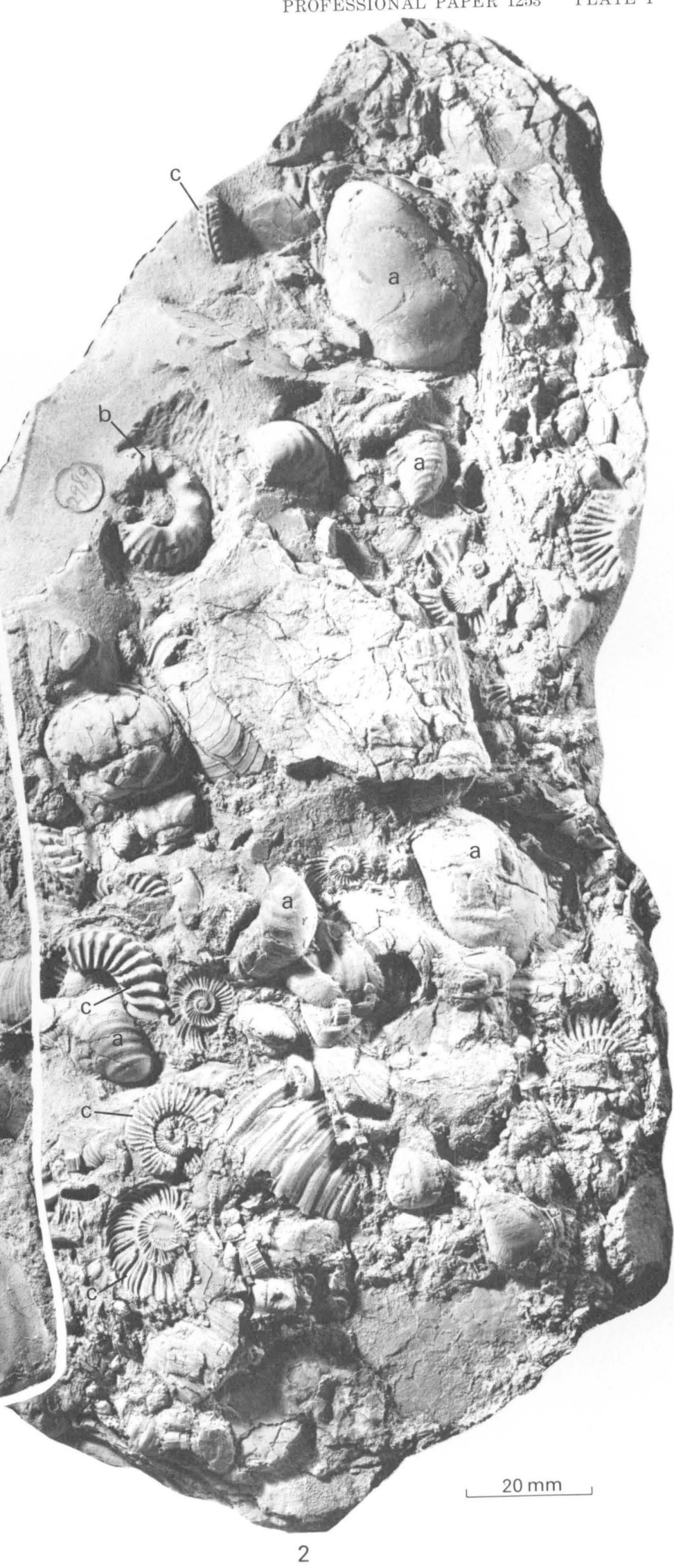

TURONIAN MOLLUSKS 


\section{PLATE 2}

[All figures natural size]

\section{Turonian bivalves}

FiguRES 1-6, 9, 10. Inoceramus apicalis Woods (p. 5).

1, 2. Left valve from USGS locality D10415 in the SW $1 / 4$ sec. 18, T. 120

N., R. 47 W., Grant County, S. Dak. USNM 299139

3, 4. Another left valve from the same locality. USNM 299140.

5,6 . Left valve from a limestone concretion in the Carlile Shale at Volcano Hill, USGS locality D10404 in sec. 3, T. 31 N., R. 5 E., Dixon County, Nebr. USNM 299141.

9, 10. Left valve from the same locality as figures 1, 2. USNM 299142.

13-16. Inoceramus howelli White (p. 6).

From a large boulder of ferruginous sandstone in the glacial drift at Granite Falls, Minn.

13, 14. Anterior view of both valves and view of right valve of UMIP $9000 \mathrm{a}$.

15, 16. Anterior view of both valves and view of left valve of UMIP $9000 \mathrm{~b}$.

\section{Cenomanian bivalves}

$7,8,11,12$. Inoceramus mesabiensis Bergquist (p. 5).

Anterior views of both valves and views of the right valves of two specimens from the Coleraine Formation at the Bennett mine (USGS locality 13766) of the Mesabi Range in the SE $1 / 4$ sec. 13, T. 57 N., R. 22 W., Itasca County, Minn. USNM 299143, 299144.

17, 18. Inoceramus ginterensis Pergament (p. 5).

From a limestone concretion in the upper part of the Graneros Shale at USGS locality D10503 in the $\mathrm{W}^{1 / 2} \mathrm{~W}^{1 / 2}$ sec. 15 , T. 90 N., R. $48 \mathrm{~W}$., Plymouth County, Iowa.

17. Right valve. USNM 299145.

18. Right valve. USNM 299146.

19, 20. Inoceramus prefragilis stephensoni Kauffman and Powell (p. 4).

From the lower part of the Graneros Shale at the Sioux City Brick and Tile Company's claypit in Riverside, Iowa.

19. Right valve. YPM 14895.

20. Left valve. YPM 14896. 
GEOLOGICAL SURVEY
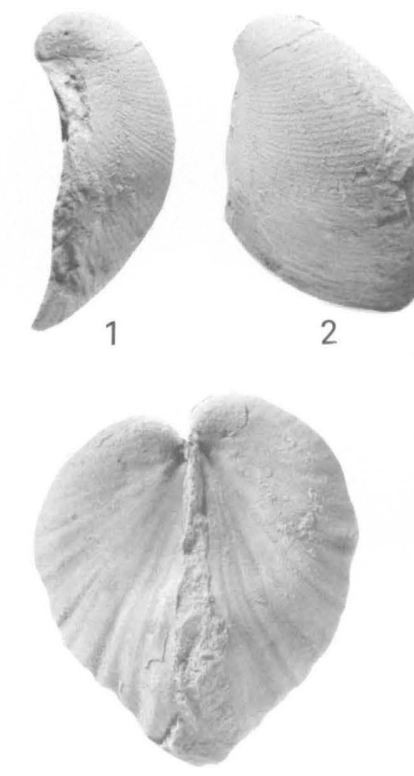

8
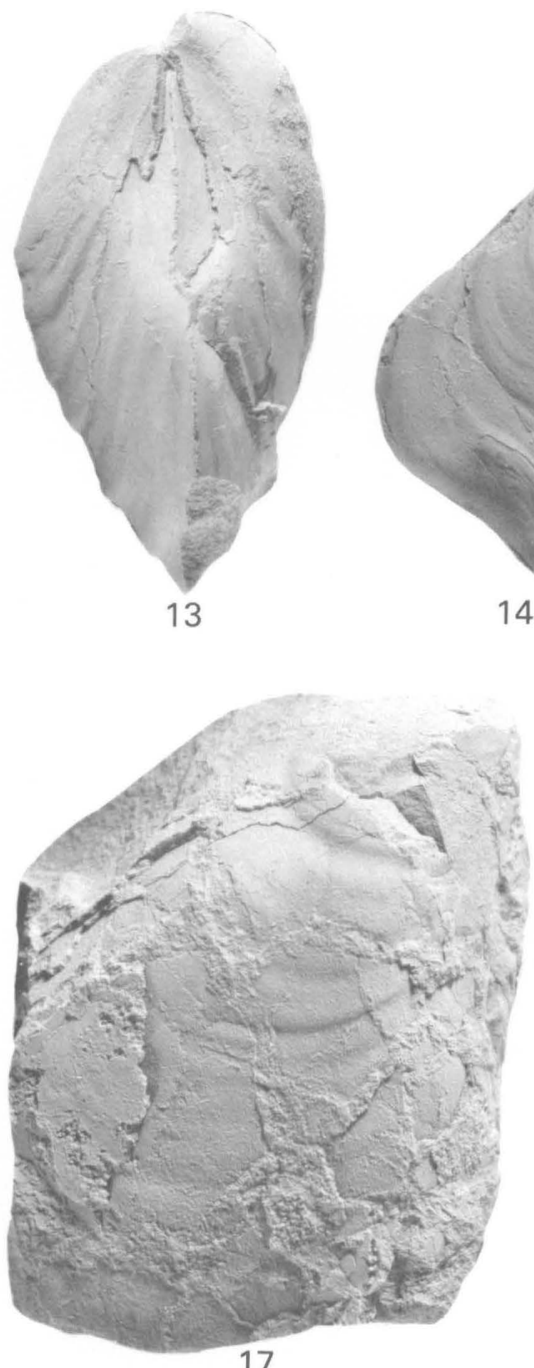

14
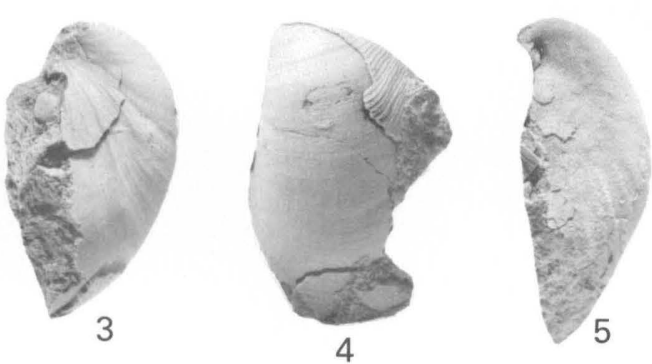

PROFESSIONAL PAPER 1253

PLATE 2
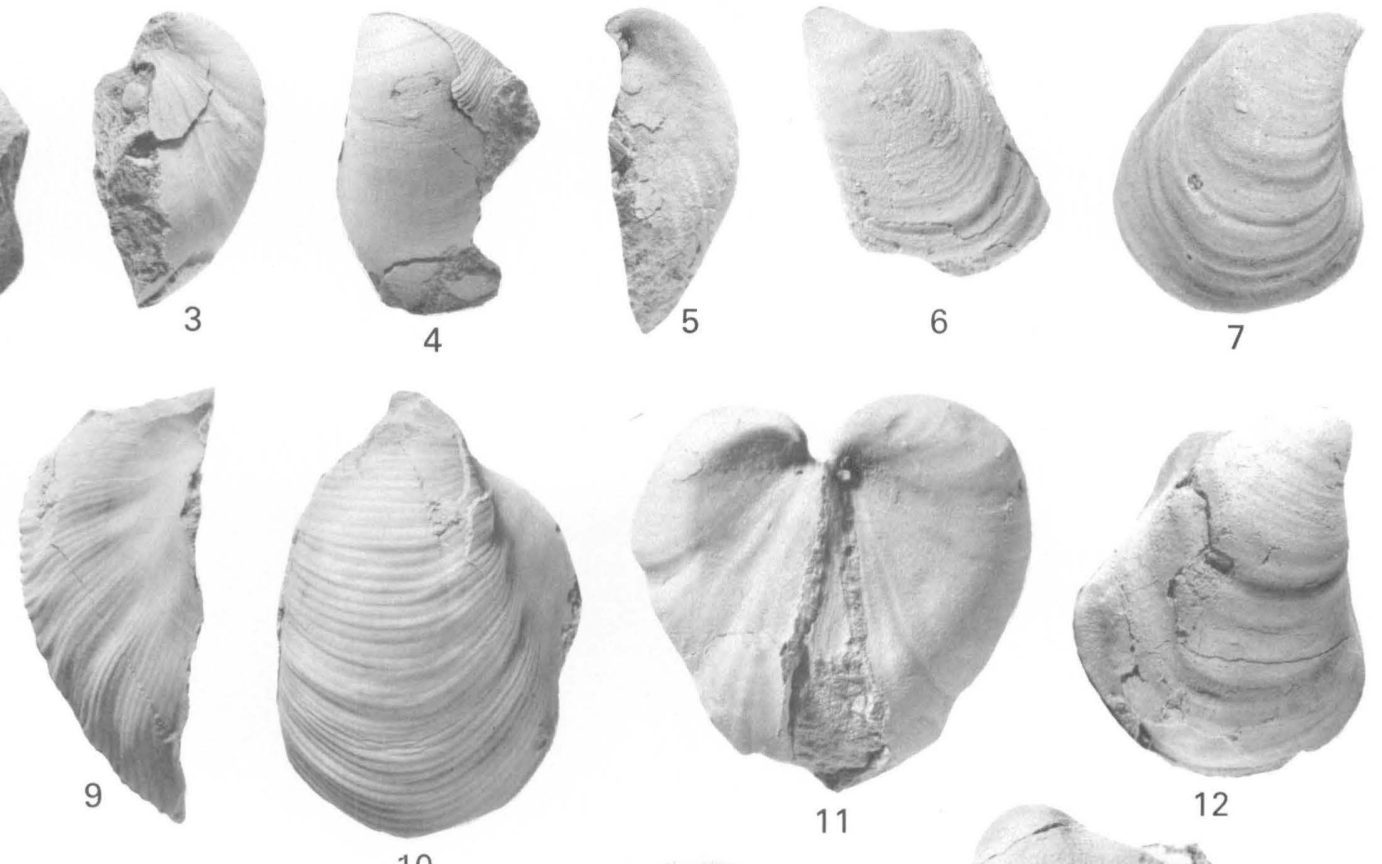

11
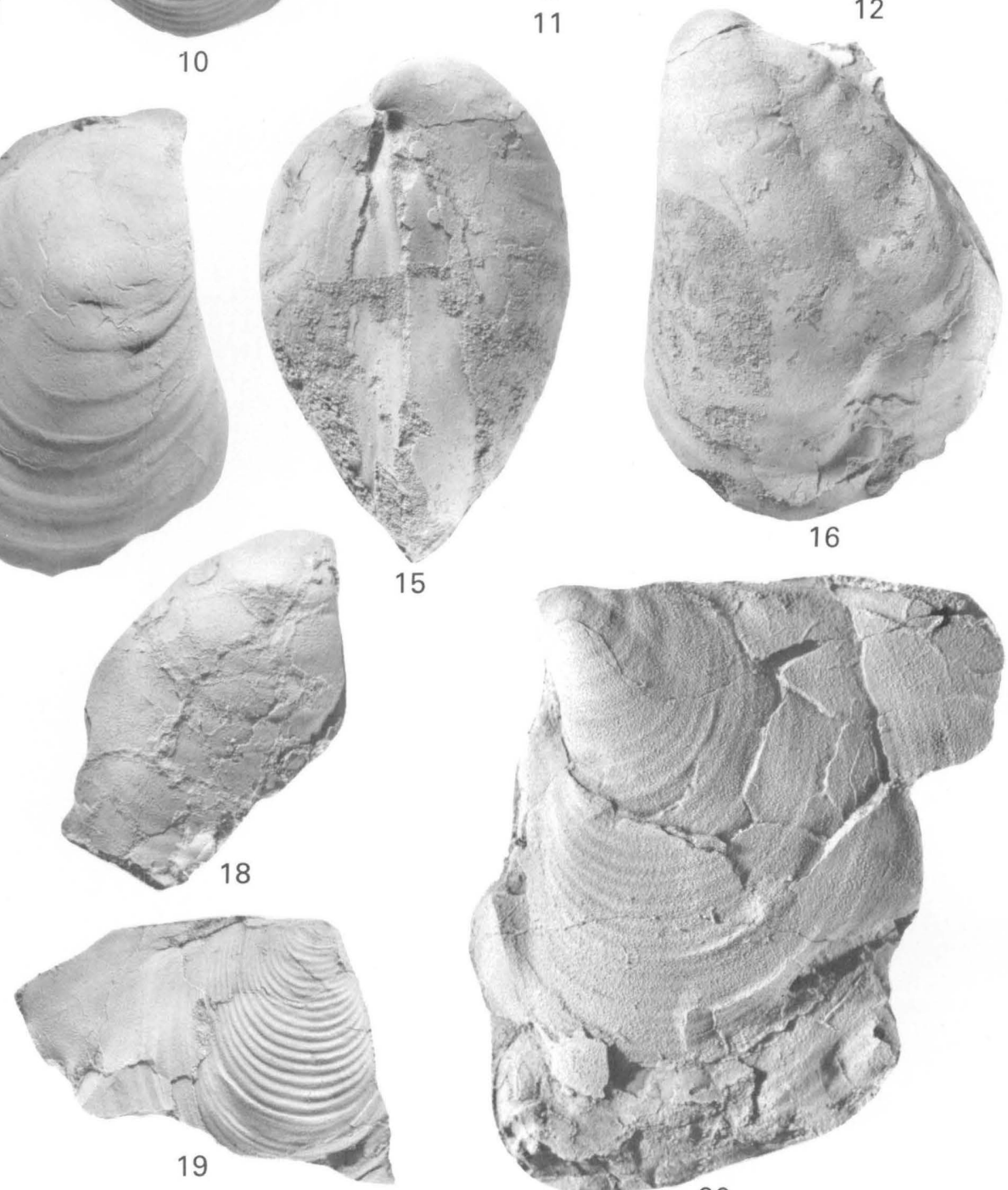

CENOMANIAN AND TURONIAN BIVALVES 


\section{PLATE 3}

[Figure natural size]

Inoceramus prefragilis stephensoni Kauffman and Powell (p. 4).

Large specimens from the basal part of the Graneros Shale in the Sioux City Brick and Tile Company's claypit in Riverside, Iowa. USNM 299147. 


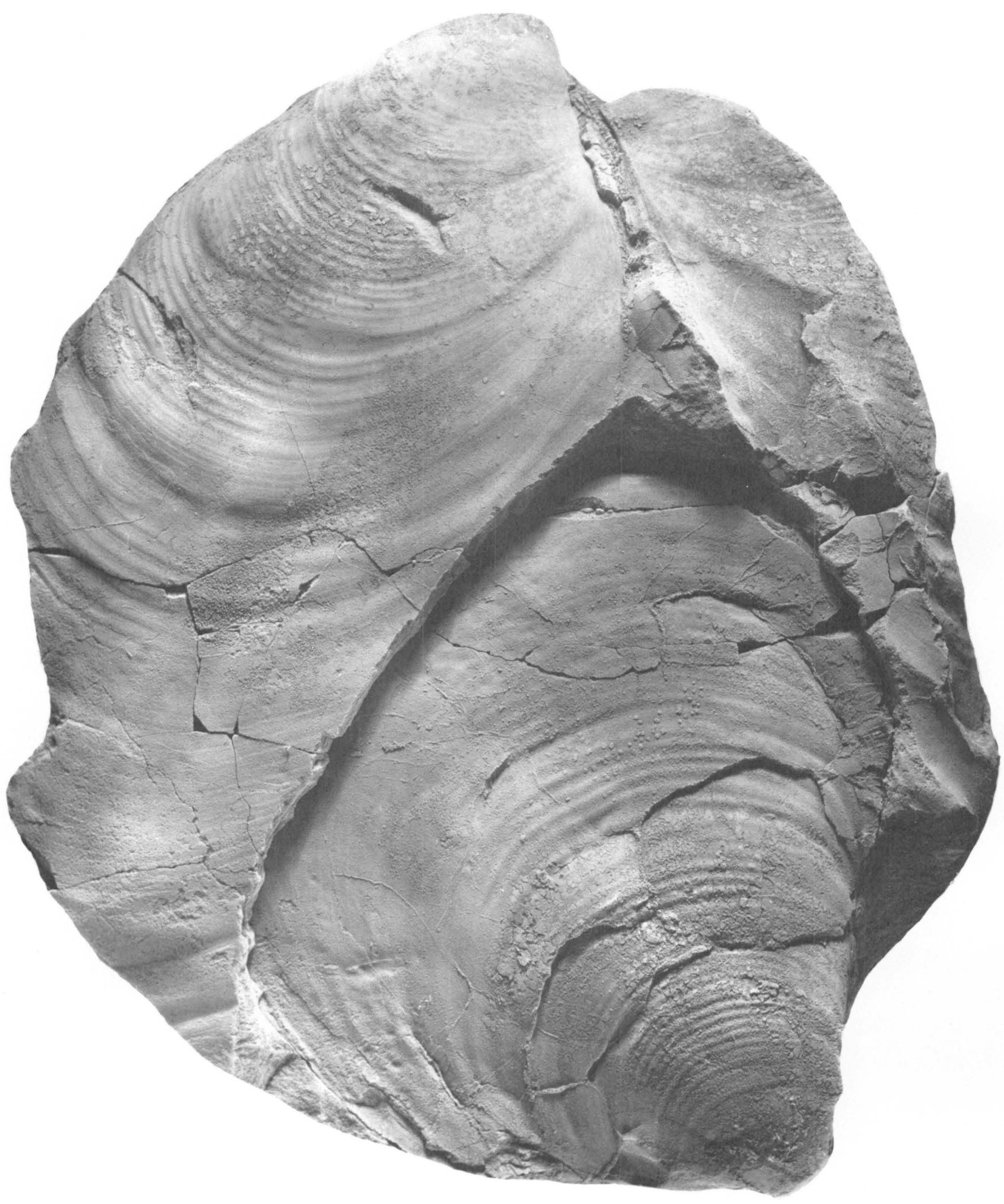

INOCERAMUS 


\section{PLATE 4}

[All figures natural size]

FiguRES 1-4. Unio barbouri White (p. 8).

From the Dakota Formation near the mouth of Two River in sec. 8, T. 127 N., R. 29

W., Morrison County, Minn.

1, 2. Lateral and dorsal views of UMIP 4566a.

3, 4. Dorsal and lateral views of UMIP 4566b.

5. Anatimya plicata Bergquist (p. 8):

View of right valve of a specimen from the Dakota Formation at the Ochs Brick and Tile Company's claypit in the NE1/4 sec. 26, T. 109 N., R. 35 W., Brown County, Minn. UMIP 9001.

6-8. Margaritifera cf. M. nebrascensis (Meek) (p. 7).

From the same locality as figures 1-4. Three views of UMIP 4567. 

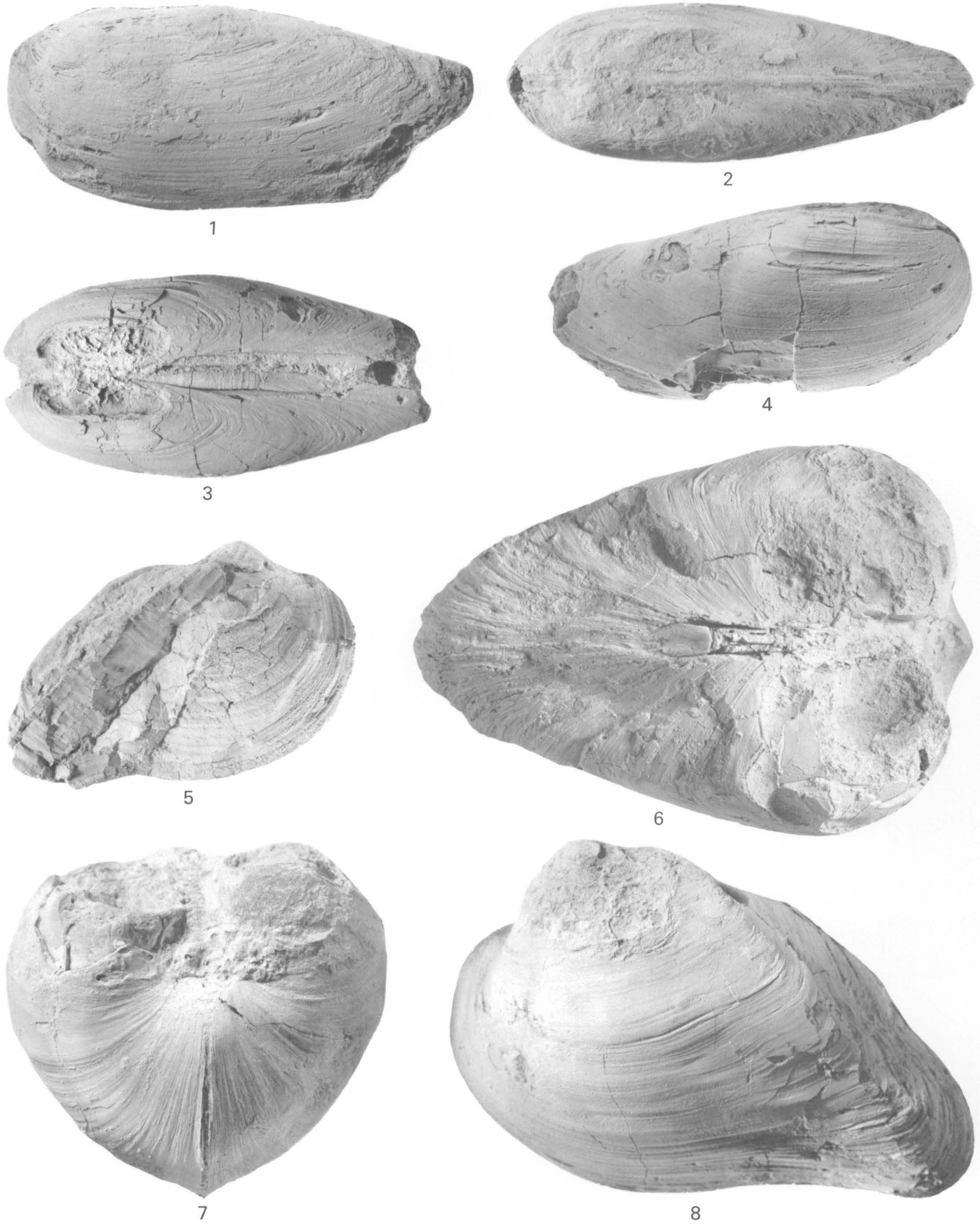

CENOMANIAN BIVALVES 


\section{PLATE 5}

[All figures natural size]

\section{Turonian ammonites}

Figures

1-3. Binneyites carlilensis Cobban (p. 16).

From concretionary limestone at the base of the Cretaceous at USGS locality D10415 in the Dakota Granite Company's quarry in the SW $1 / 4$ sec. 18, T. 120 N., R. 47 W., Grant County, S. Dak.

1, 2. USNM 299148.

3. USNM 299149.

4, 5. Tragodesmoceras carlilense Cobban (p.11)

From the same locality as figures 1-3 (USGS loc. D10415). USNM 299150.

6-11, 16, 17. Otoscaphites seabeensis Cobban and Gryc (p. 11).

From the same locality as figures 1-3 (USGS loc. D10415).

6-8. Side, top, and rear views of a small adult body chamber. USNM 299151.

9. Side view of a broken body chamber. USNM 299152.

10, 11. Rear and side views of USNM 299153.

16, 17. Side and rear views of USNM 299154.

12-15, 18-23. Scaphites delicatulus sloani Cobban, n. subsp. (p. 8).

From the same locality as figures 1-3 (USGS loc. D10415).

12-15. Top, rear, side, and front views of the holotype. USNM 299155.

18, 19. Views of a phragmocone showing rursiradiate ribbing. USNM 299156.

20, 21. Front and side views of USNM 299157.

22,23 . Side and rear views of USNM 299158.

24, 25. Scaphites corvensis Cobban (p. 9).

From some depth between 50 and $70 \mathrm{~m}$ in the Minnesota Department of Conservation's water well in the NE 1/4 SE $1 / 4$ sec. 32, T. 111 N., R. $42 \mathrm{~W}$., Lyon County, Minn. UMIP 8284.

26-37. Subprionocyclus percarinatus (Hall and Meek) (p. 18).

From the Carlile Shale at Volcano Hill, USGS locality D10404 in sec. 3, T. 31 N., R. 5 E., Dixon County, Nebr.

26. Latex cast of a small specimen. USNM 299159.

27, 28. USNM 299160.

29. USNM 299161.

30, 31. USNM 299162.

32, 33. USNM 299163.

34. Lectotype, from Hall and Meek, 1856, pl. 4, fig. 2b.

35. Imprint on gray shale. USNM 299164.

36,37 . USNM 299165.

38-42. Collignoniceras vermilionense (Meek and Hayden) (p. 17).

38. Plaster cast of holotype, USNM 224.

39 , 40. Rear and side views of a small adult that has conspicuous siphonal clavi but lacks clearly defined ventrolateral tubercles. From a limestone concretion in the Carlile Shale at the same locality as figures 26-37 (USGS loc. D10404). USNM 299166.

41, 42. Side and rear views of a small adult that has ventrolateral horns and a conspicuous keel, from the same locality as figures 26-37 (USGS loc. D10404). USNM 299167. 
GEOLOGICAL SURVEY

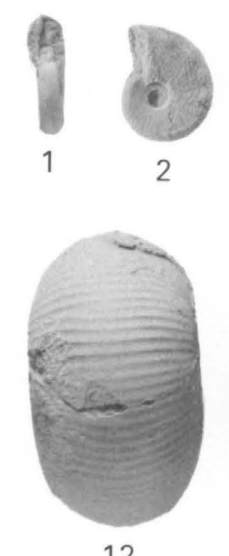

12

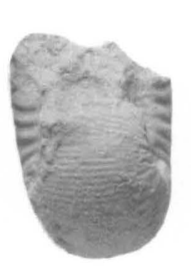

20
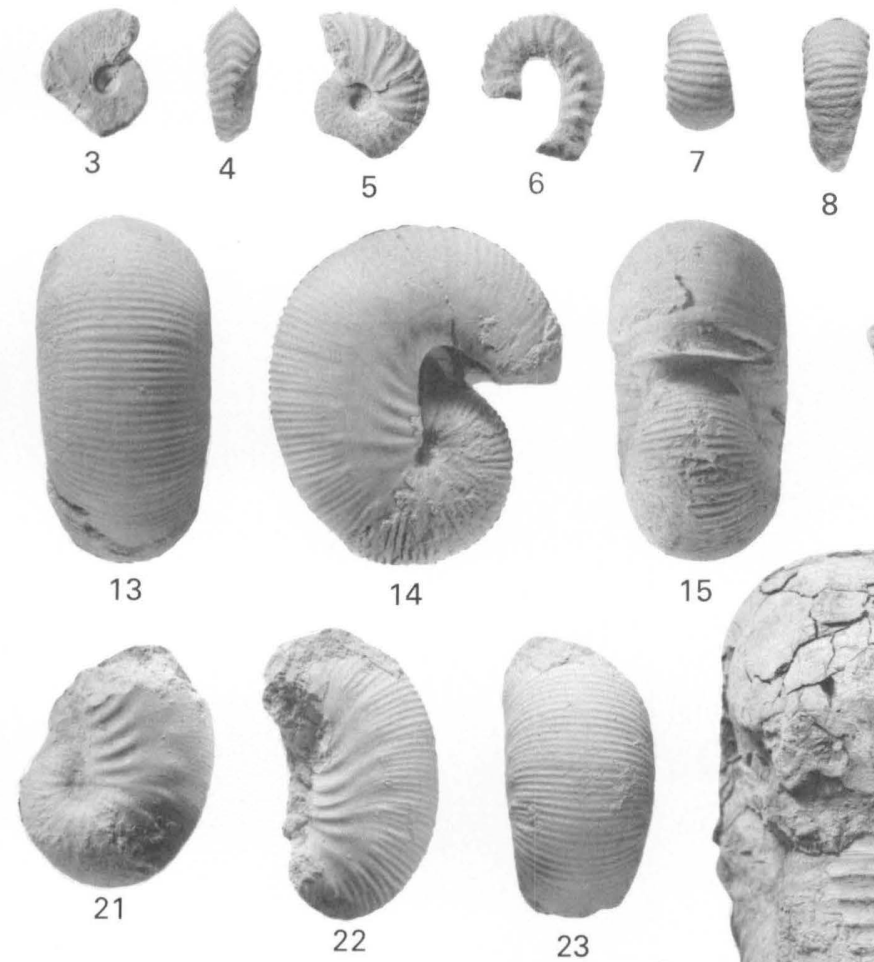

-
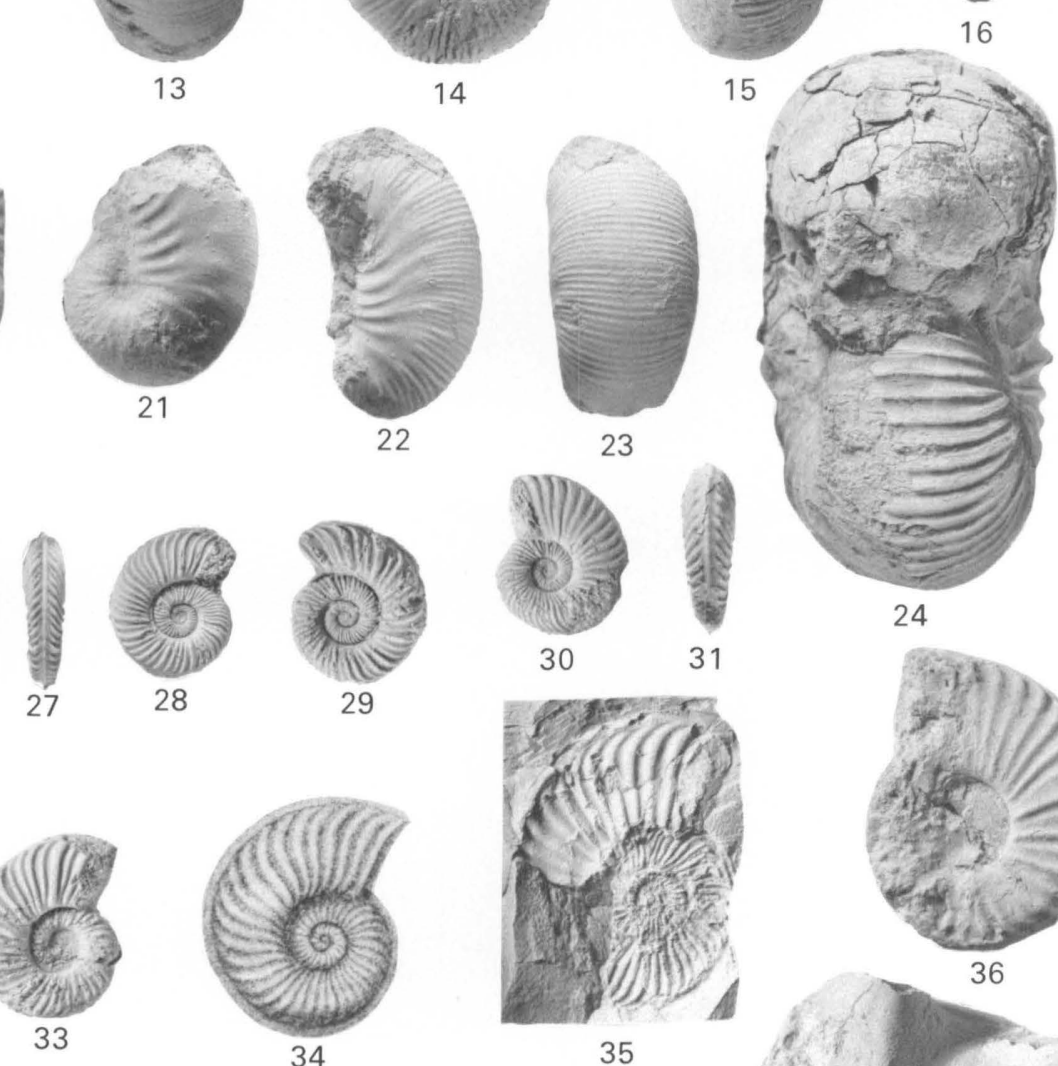

PROFESSIONAL PAPER 1253

PLATE 5

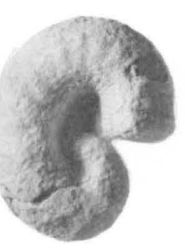

11

10

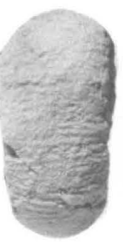

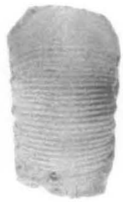

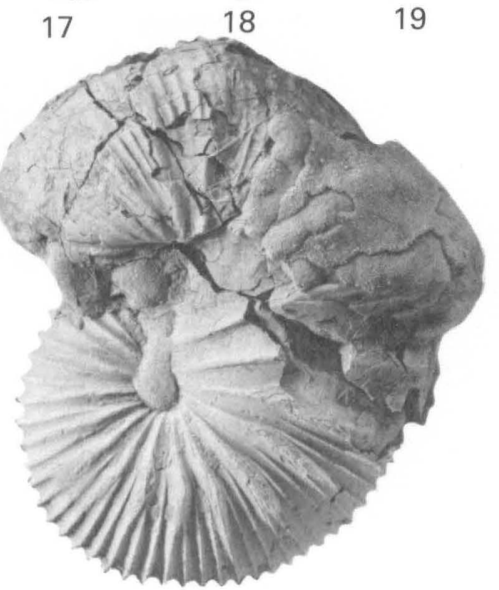

25
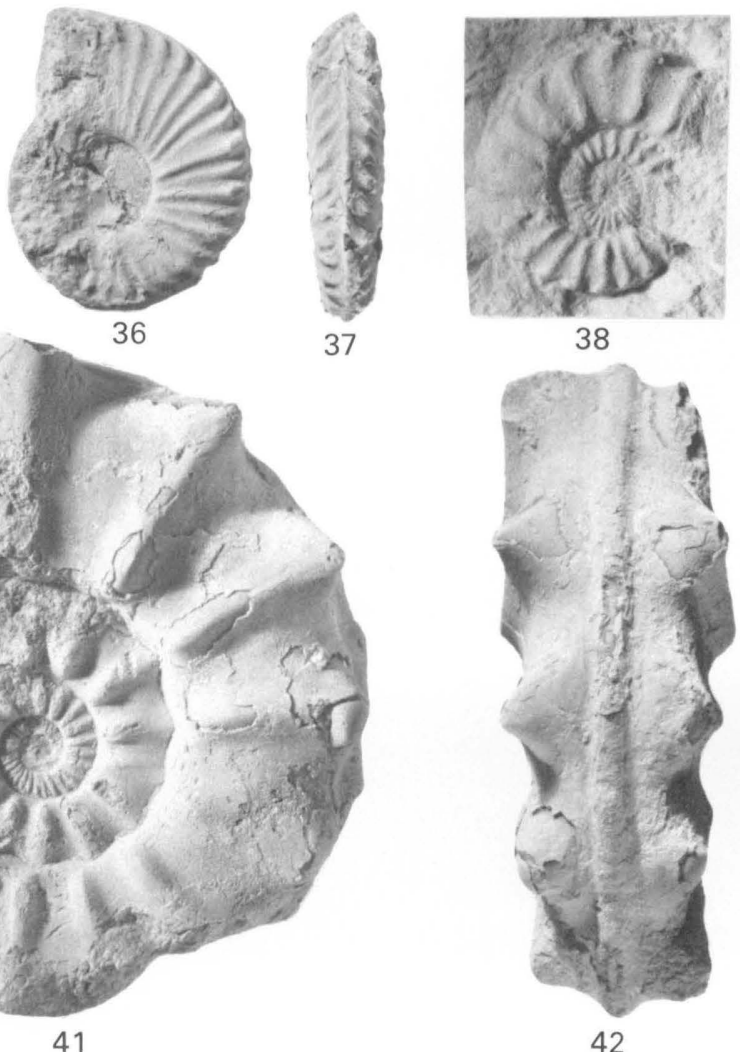

TURONIAN AMMONITES 


\section{PLATE 6}

[Natural size]

Slab of gray shale from near the base of the Graneros Shale at the Sioux City Brick and Tile Company's claypit, Riverside, Iowa, containing a crushed specimen of the smooth ammonite Metengonoceras dumbli (Cragin) (SCPM F259D) and above it the ornamented inner whorls of Dunveganoceras pondi Haas (SCPM F259C). 


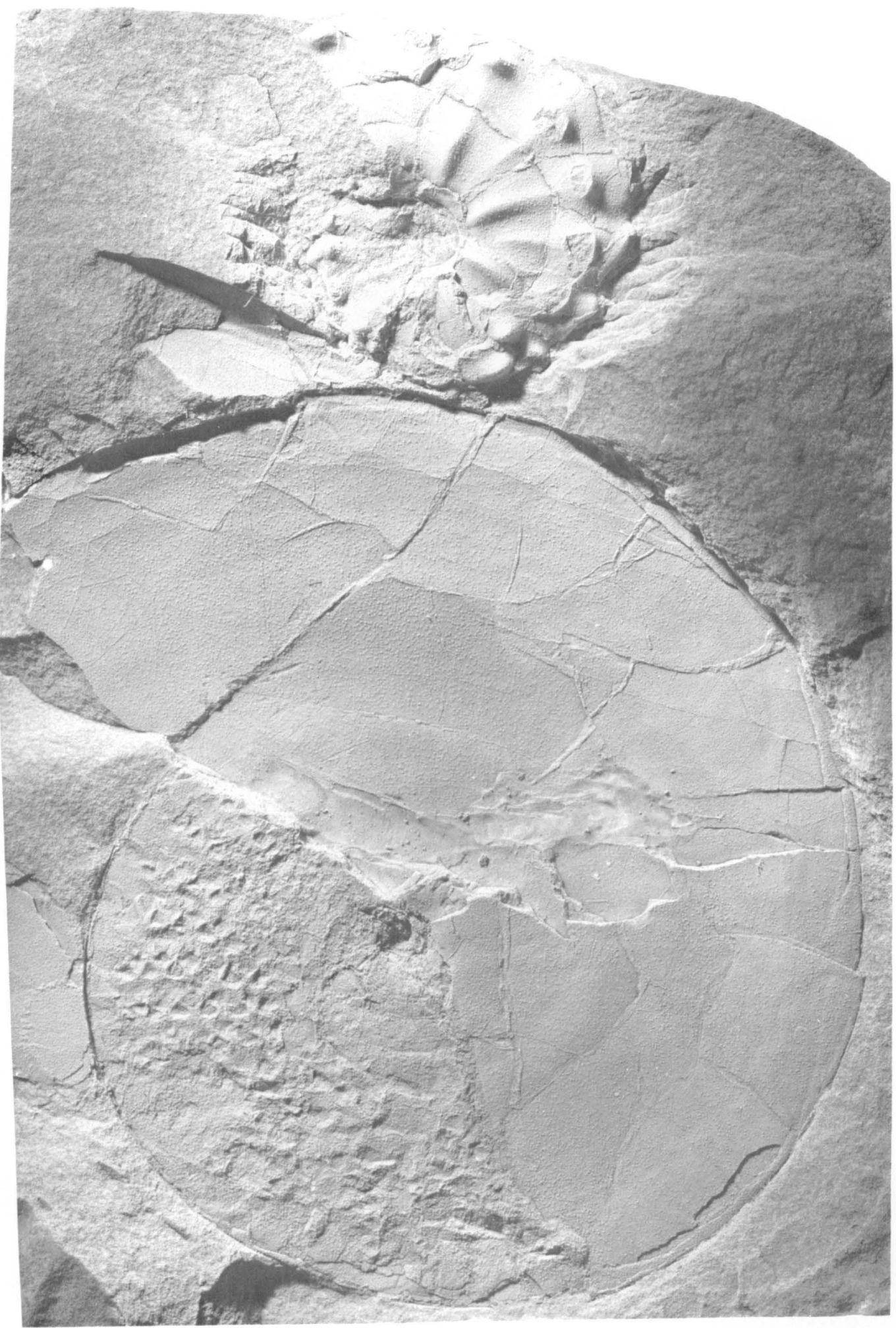




\title{
PLATE 7
}

\author{
[All figures natural size]
}

FiguRes 1, 2. Proplacenticeras stantoni (Hyatt) (p. 12).

Front and side views of a phragmocone from concretionary limestone at the base of the Cretaceous at USGS locality D10415, in the Dakota Granite Company's quarry in the SW $1 / 4$ sec. 18, T. 120 N., R. 47 W., Grant County, S. Dak. USNM 299168.

3-5. Proplacenticeras pseudoplacenta (Hyatt) (p. 11).

3. A small phragmocone having falcoid ribs from the same locality as figures 1 , 2 (USGS loc. D10415). USNM 299169.

4,5 . Side and rear views of a phragmocone from the same locality. USNM 299170.

6, 7. Actinocamax sp. (p. 20).

From the same locality as figures 1,2 .

6. Broken specimen lying beside a piece of fossil bone. USNM 299171.

7. Another fragment split longitudinally. USNM 299172.

8. Metengonoceras dumbli (Cragin) (p. 11).

A crushed specimen of an adult that has part of the body chamber. From gray silty shale near base of Graneros Shale in the Sioux City Brick and Tile Company's claypit, Riverside, Iowa. SCPM F259B. 
GEOLOGICAL SURVEY

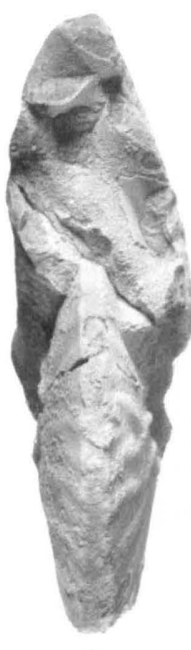

1
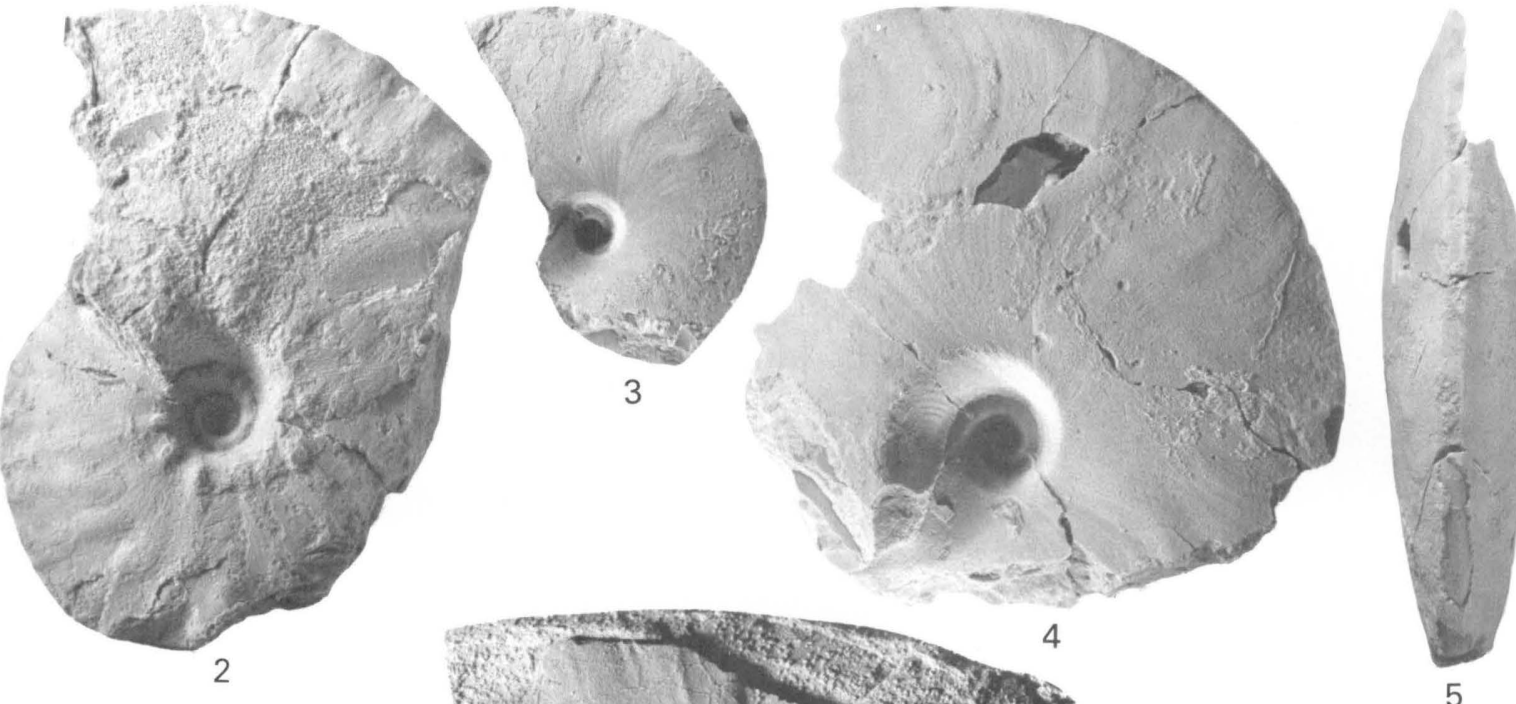

5

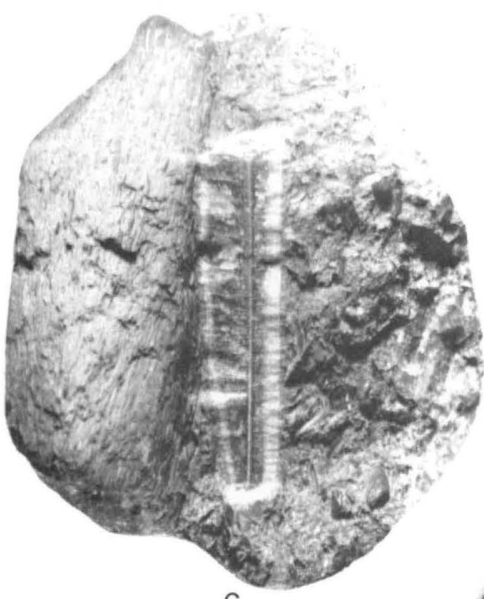

6

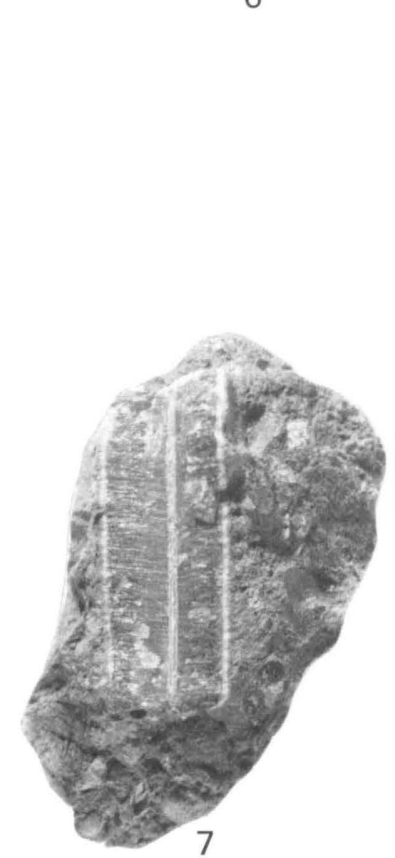

PROPLACENTICERAS, METENGONOCERAS, AND ACTINOCAMAX 


\section{PLATE 8}

[All figures natural size]

\section{Cenomanian ammonite}

FiguRES 1-4. Metoicoceras bergquisti Cobban, n. sp̃. (p. 14).

1, 2. Most of the body chamber of a small adult from the Coleraine Formation at the Hill Annex mine, Calumet, Minn. (USGS loc. 13063). UMIP 9008.

3 , 4. Older part of a larger body chamber from the Coleraine Formation from the same locality as figures 1 and 2. (USGS 13063). USNM 299173.

\section{Turonian mollusks}

5, 6. Metengonoceras dumbli (Cragin) (p. 11).

From the Coleraine Formation near Calumet, Minn. Collected by Blaine Conley, Swan River, Minn. USNM 299174.

7. Mytiloides labiatus (Schlotheim) (p. 6).

From sandy limestone, which fills a fissure in Precambrian granite, at USGS locality D10420 (Delano quarry), in the $\mathrm{SE}^{1 / 4} \mathrm{SE}^{1 / 4} \mathrm{sec} .16, \mathrm{~T} .120$ N., R. $45 \mathrm{~W}$., Lac Qui Parle County, Minn. USNM 299175.

8, 9. Mytiloides mytiloides (Mantell) (p. 6).

8. A fragment from the same locality as figure 7. USNM 299176.

9. Latex cast of another specimen from the same locality as figure 7. USNM 299177.

10. Inoceramus apicalis Woods (p. 10).

Part of a right(?) valve from the same locality as figure 7. USNM 299178.

\section{Coniacian ammonite}

11-13. Scaphites preventricosus (Cobban) (p. 10).

Found by Phyllis Regnier on farm $1.6 \mathrm{~km}$ north of Ghent, Lyon County, Minn. UMIP 9007. 

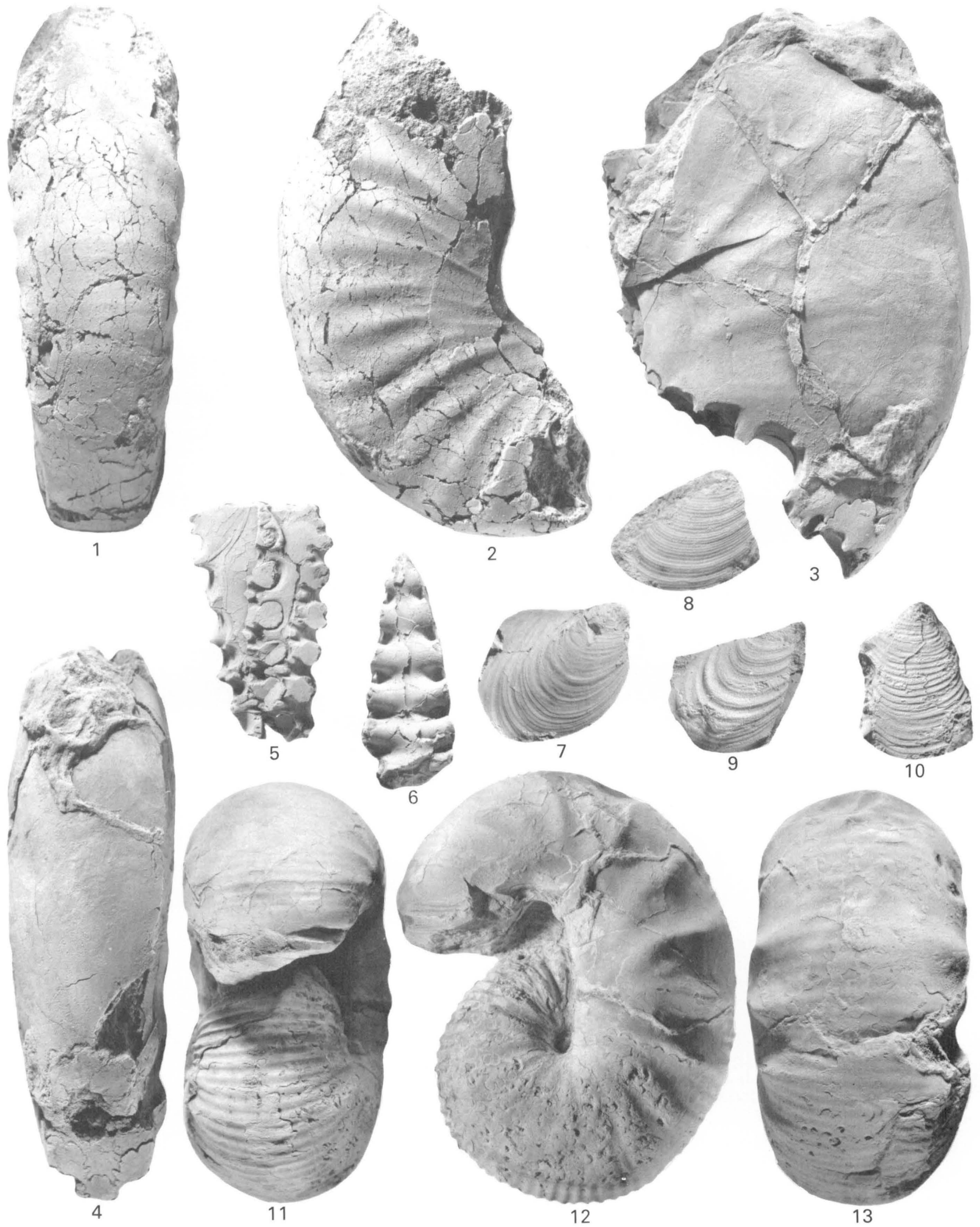

CENOMANIAN, TURONIAN, AND CONIACIAN MOLLUSKS 


\section{PLATE 9}

[Natural size $]$

Dunveganoceras pondi Haas (p. 12).

Side view of a partly crushed adult from the basal part of the Graneros Shale in the Sioux City

Brick and Tile Company's claypit, Riverside, Iowa. An unnumbered specimen at the Sioux City Public Museum, Sioux City, Iowa. 


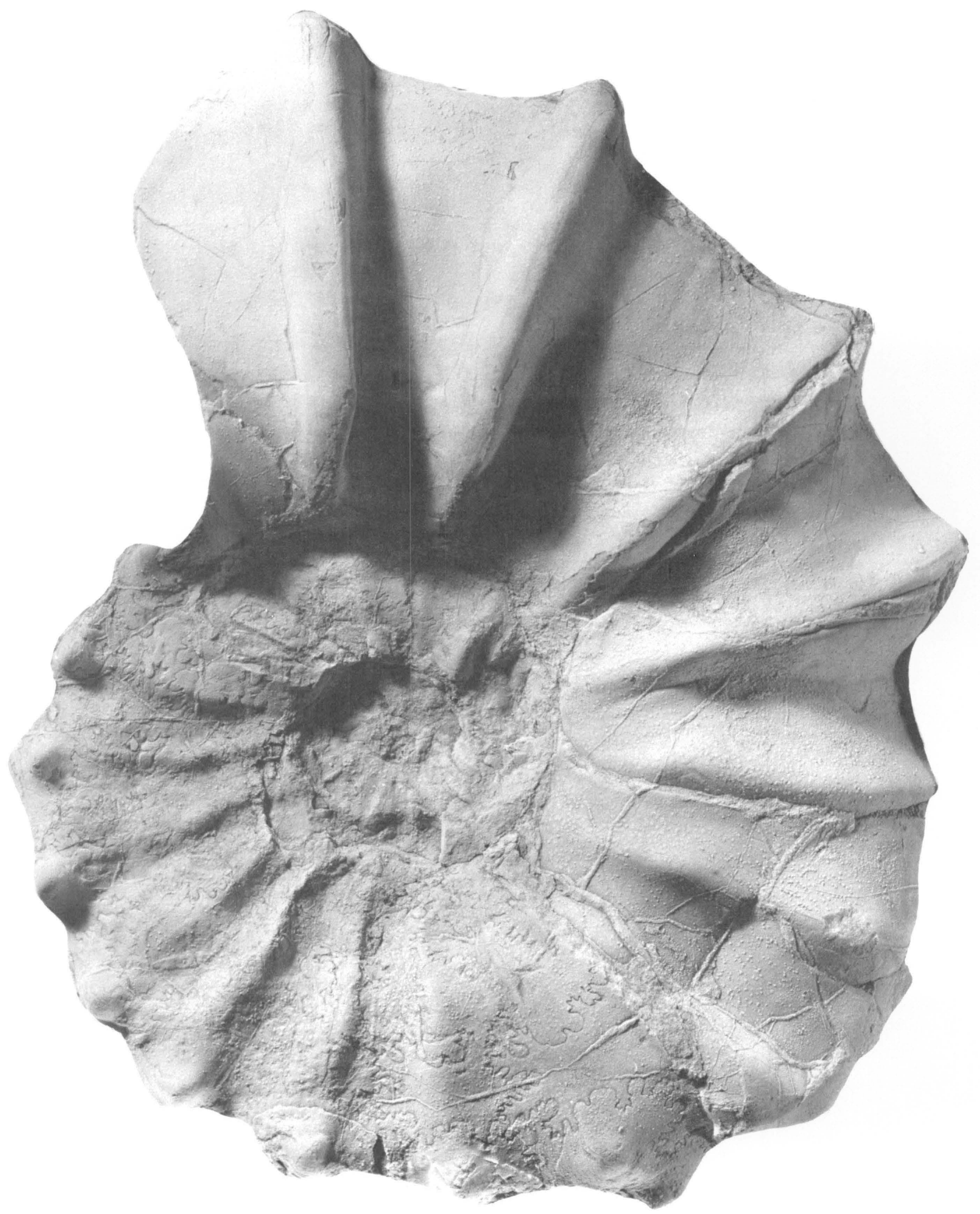




\section{PLATE 10}

[Figure 1 natural size; figure 2 about 0.6 natural size]

Figure 1. Dunveganoceras pondi Haas (p. 12).

Rear view of an adult body chamber from the basal part of the Graneros Shale in the Sioux City Brick and Tile Company's claypit, Riverside, Iowa. YPM 14897.

2. Dunveganoceras hagei Warren and Stelck (p. 13).

Rear view of the specimen shown on plate 11. 


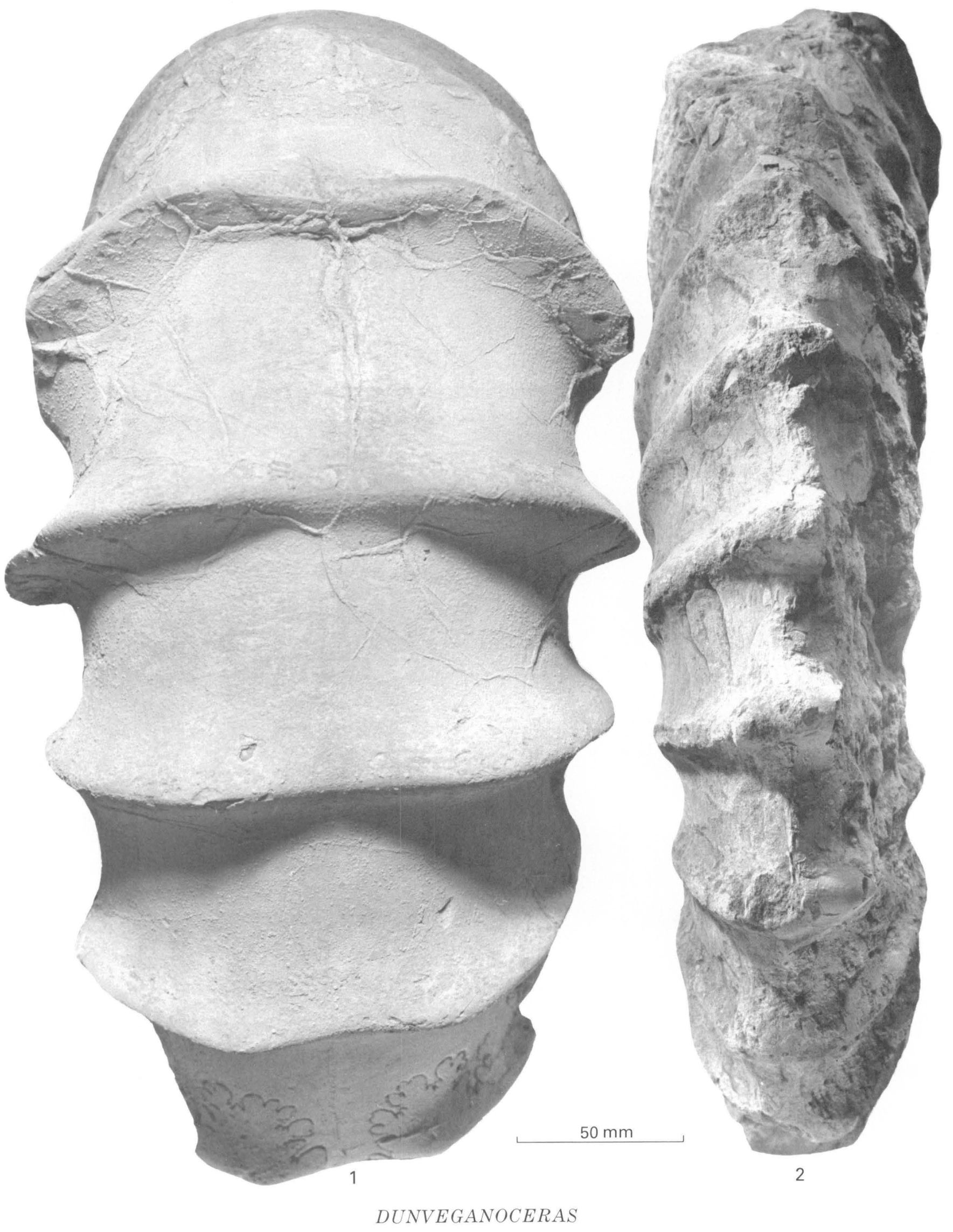




\section{PLATE 11}

[A bout 0.6 natural size]

Dunveganoceras hagei Warren and Stelck (p. 13).

From the Coleraine Formation at the Hill Annex mine, Calumet, Minn. This specimen is at the Department of Geology, University of Minnesota, Duluth. 


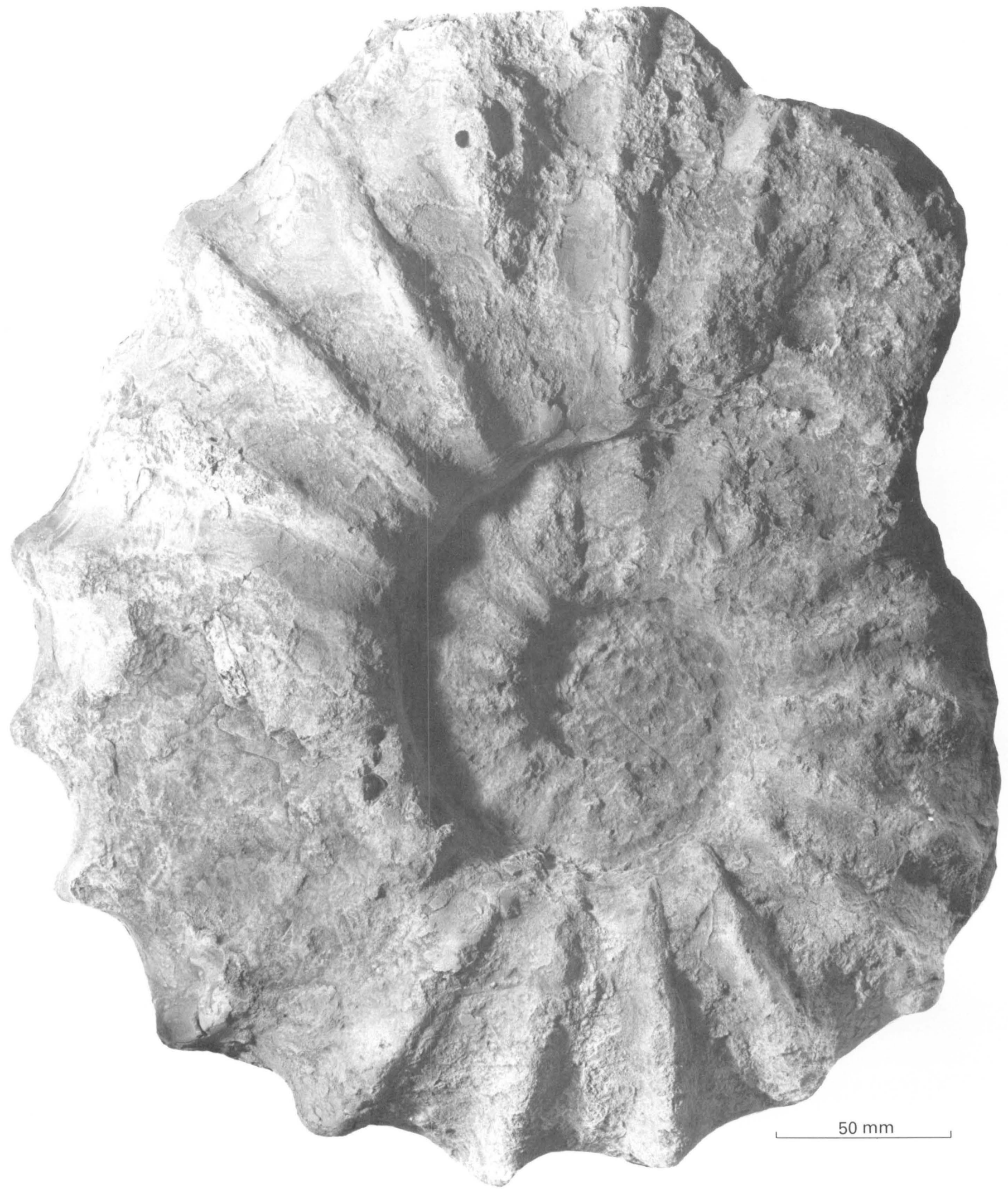




\section{PLATE 12}

[All figures natural size]

Figures 1-5. Metoicoceras bergquisti Cobban, n. sp. (p. 14).

1-3. Ornamented variant from the Coleraine Formation at the Hill Annex mine, Calumet, Minn. The small specimen is part of the inner whorls. UMIP 6178 .

4, 5. Part of a phragmocone from the same locality as figures 1-3. UMIP 9005a.

6, 7. Dunveganoceras hagei Warren and Stelck (p. 13)

Older part of an adult body chamber from the same locality as figures 1-5. UMIP 5058 . 

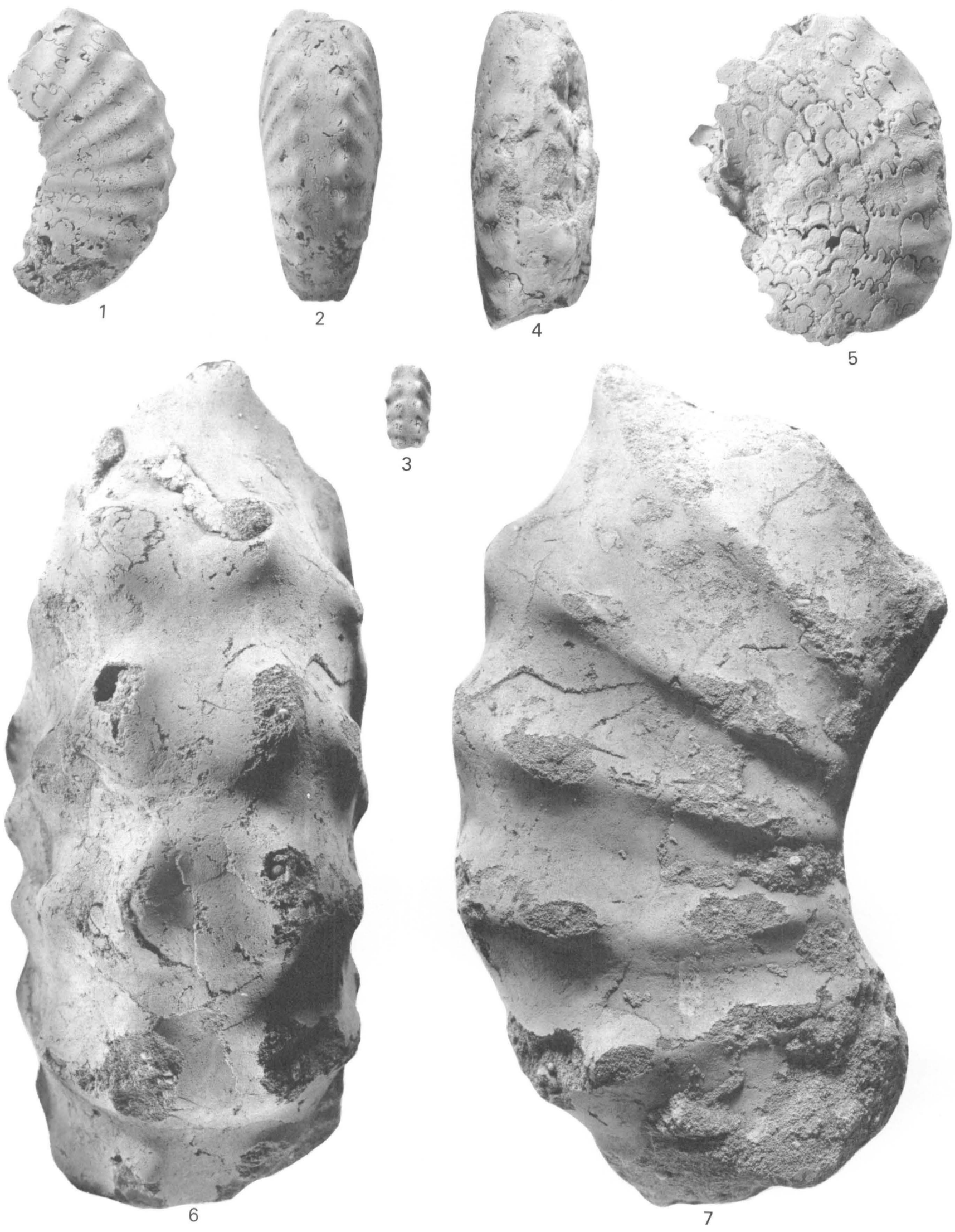

METOICOCERAS AND DUNVEGANOCERAS 


\section{PLATE 13}

[Figures natural size]

Figures 1, 2. Metoicoceras bergquisti Cobban, n. sp. (p. 14).

Part of a very large adult body chamber from the basal part of the Coleraine Formation at the Hill Annex mine, Calumet, Minn. Paratype UMIP 9003. 

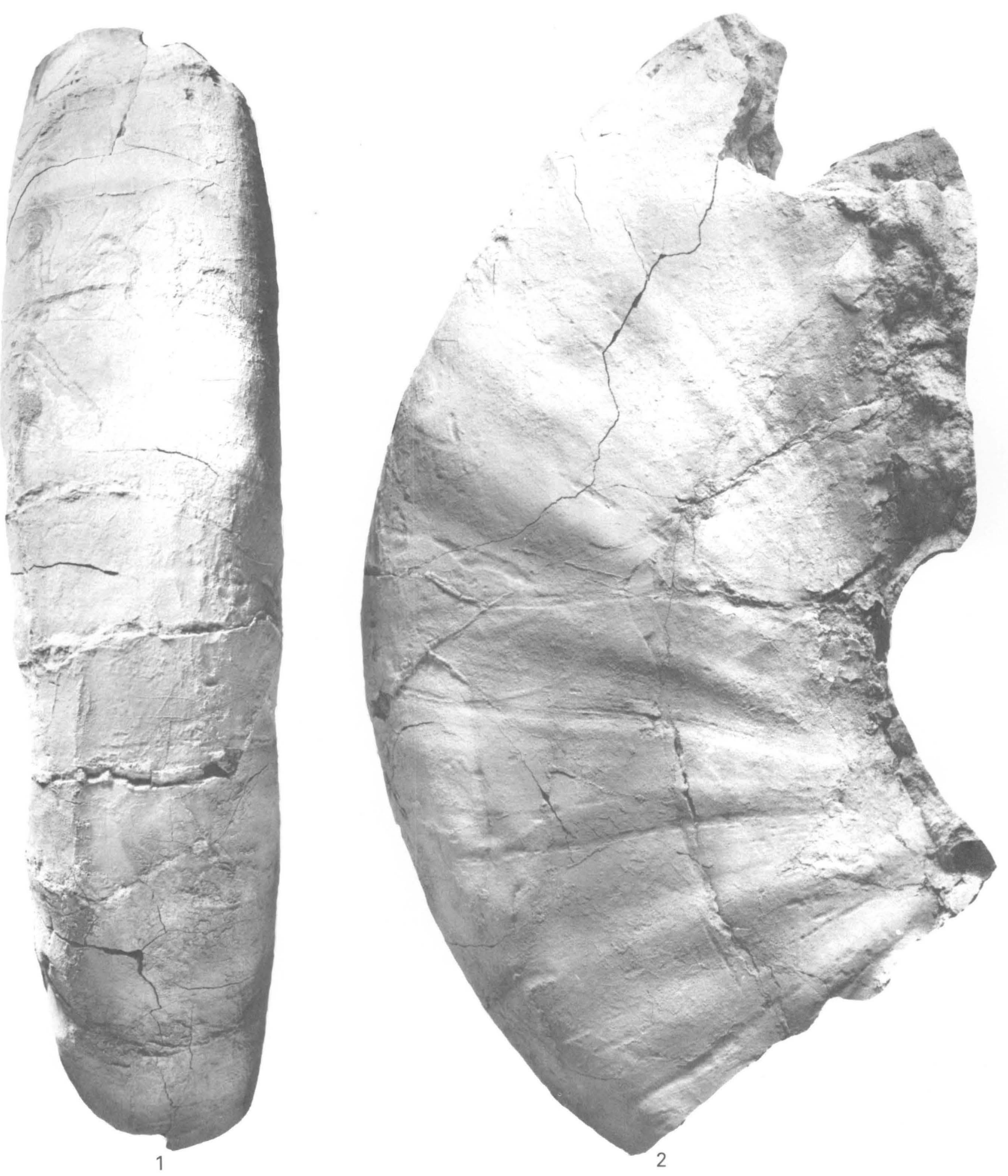

METOICOCERAS 


\section{PLATE 14}

[All figures natural size]

\section{Cenomanian ammonite}

FiguRES 1-5, 10-15. Metoicoceras bergquisti Cobban, n. sp. (p. 14).

1-3. Holotype, the older part of a small adult body chamber from the basal part of the Coleraine Formation at the Arcturus mine, Marble, Minn. Figure 3 is a latex cast of the last inner whorl. UMIP 9004.

4, 5. Part of a phragmocone from the basal part of the Coleraine Formation at the Hill Annex mine, Calumet, Minn. Paratype UMIP 9005b.

10, 11. Part of a smooth phragmocone from USGS locality 13060, Arcturus mine, Marble, Minn. Paratype USNM 299182.

12-15. Older two-thirds of an adult body chamber from the same locality as figures 4 and 5 . Figures 12 and 13 are of a latex cast of part of the last inner whorl. Paratype UMIP 5061.

\section{Turonian ammonite}

6-8. Baculites yokoyamai Tokunaga and Shimizu (p. 16).

From concretionary limestone at the base of the Cretaceous at USGS locality D10415 in the Dakota Granite Company's quarry in the SW $1 / 4$ sec. 18, T. 120 N., R. 47 W., Grant County, S. Dak.

6,7 . Ventral and lateral views of a juvenile with most of its shell material. USNM 299179.

8. Lateral view of part of a deformed phragmocone. USNM 299180.

\section{Cenomanian bivalve}

9. Sanoarca siouxensis (Hall and Meek) (p. 1).

Latex cast of a right valve from the Windrow Formation (as used in Minnesota) at USGS locality D10507 in the Ochs Brick and Tile Company's claypit in the $\mathrm{SE}^{1 / 4} \mathrm{NE}^{1 / 4}$ sec. 26, T. 109 N., R. 35 W., Brown County, Minn. USNM 299181. 

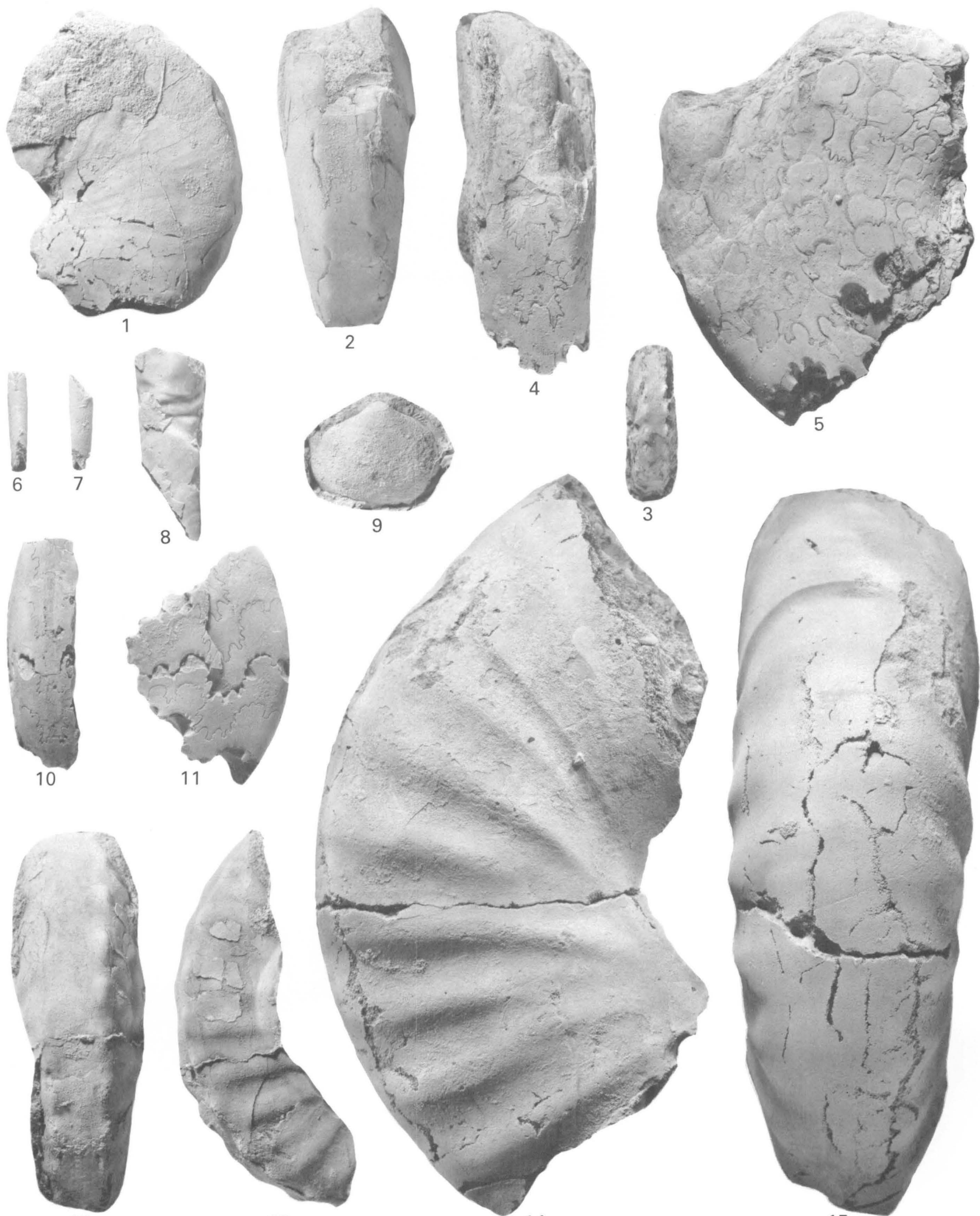

12

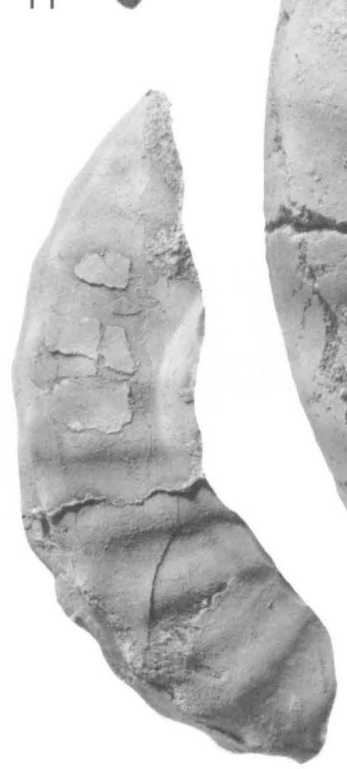

13

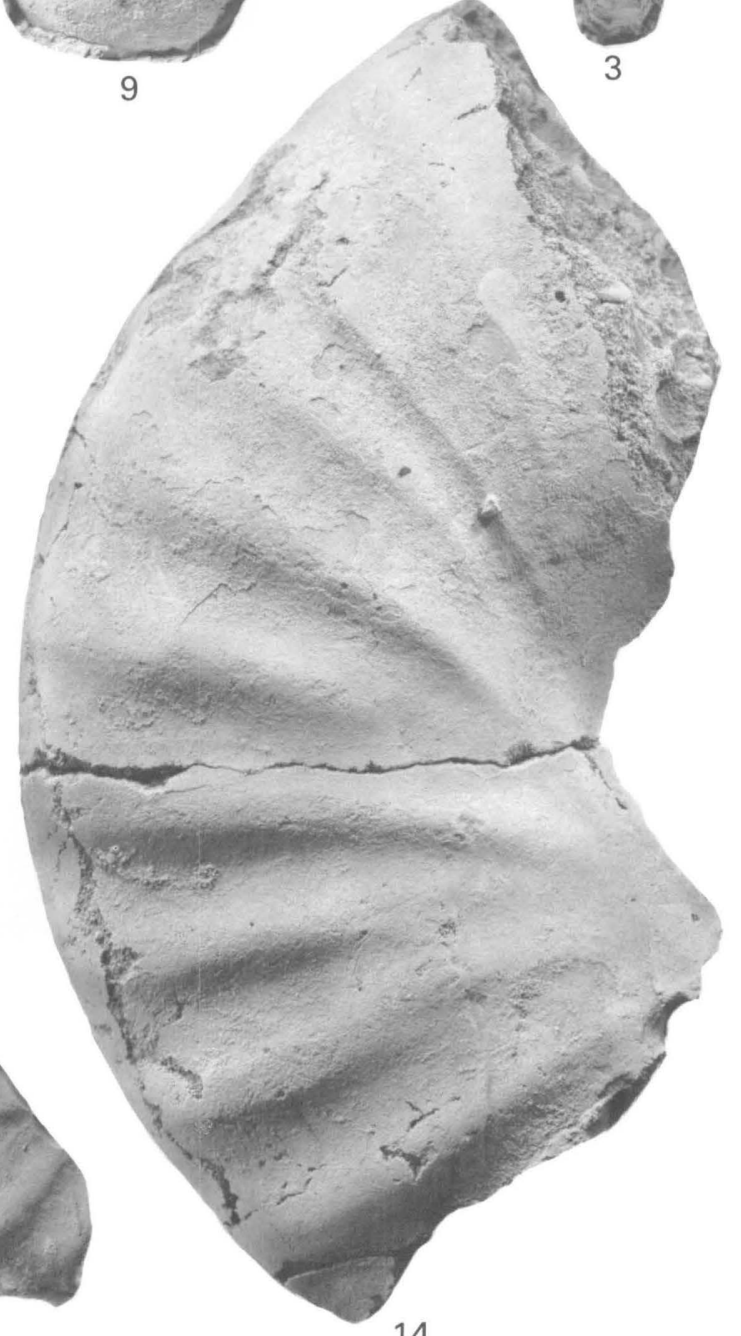

14

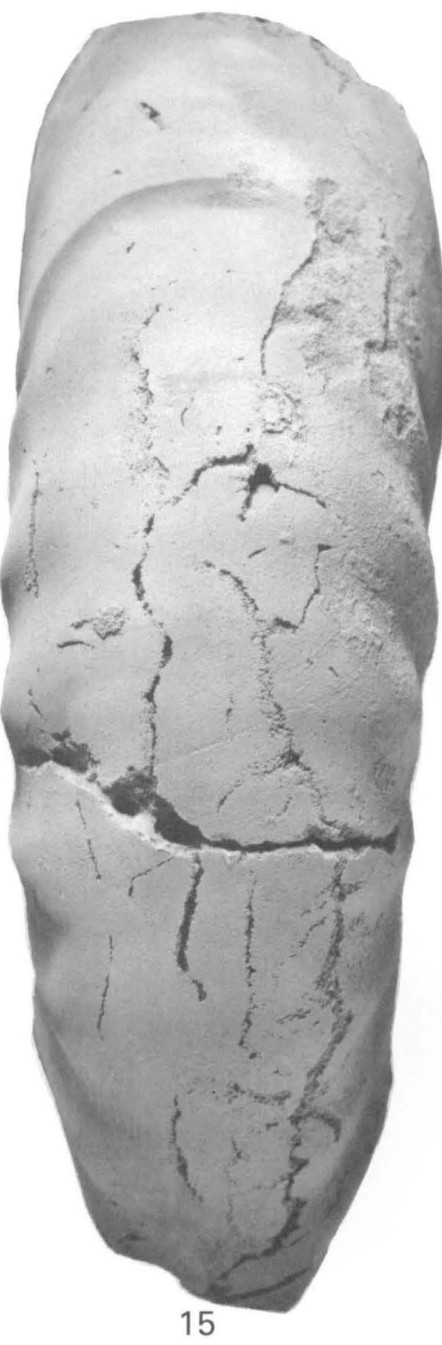

CENOMANIAN AND TURONIAN MOLLUSKS 


\section{PLATE 15}

[All figures natural size]

\section{Cenomanian ammonite}

FIGURE 1. Dunveganoceras pondi Haas (p. 12).

Side view of part of a small phragmocone from a limestone concretion in the Graneros Shale at USGS locality D10412 in the SW $1 / 4 \mathrm{NW}^{1 / 4}$ sec. 4, T. 90 N., R. 48 W., Plymouth County, Iowa. USNM 299183.

\section{Turonian ammonites}

2-4, 7-11. Collignoniceras woollgari regulare (Haas) (p. 16).

2. Coarse-ribbed form from concretionary limestone at the base of the Cretaceous at USGS locality D10415 in the Dakota Granite Company's quarry in the SW $1 / 4$ sec. 18 , T. 120 N., R. 47 W., Grant County, S. Dak. USNM 299184

3 , 4. Small specimens from the same locality as figure 2 showing dense even ribbing on early whorls. USNM 299185, 299186.

7, 8. A larger specimen from the same locality as figure 2. USNM 299187.

9. Fragment of an adult body chamber from the same locality as figure 2. USNM 299188.

10. Latex cast from the same locality as figure 2 showing parts of several whorls. USNM 299189.

11. Sketch of part of a whorl found in the glacial drift near Warsaw, Ill. (from Worthen, 1890)

5, 6. Subprionocyclus percarinatus (Hall and Meek)? (p. 19)

Latex cast of a specimen in a clay ironstone concretion found in the glacial drift south of Minneapolis in the $\mathrm{S} 1 / 2$ sec. 13, T. 115 N., R. 21 W., Dakota County, Minn. UMIP 9006.

12. Watinoceras coloradoense (Henderson) (p. 15)

Float specimen from the Greenhorn Formation at USGS locality D10578 in the NE $1 / 4 \mathrm{SE}^{1 / 4}$ sec. 2, T. 125 N., R. 49 W., Traverse County, Minn. USNM 299190.

\section{Coniacian bivalve}

13, 14. Volviceramus involutus (J. de C. Sowerby) (p. 7).

Right valve encrusted with Pseudoperna congesta (Conrad) from $1.5 \mathrm{~m}$ above base of Niobrara Formation at USGS locality D10408 in the NE $1 / 4 \mathrm{SW}^{1 / 4}$ sec. 24, T. 33 N., R. 1 E., Cedar County, Nebr. USNM 299191. 
GEOLOGICAL SURVEY

PROFESSIONAL PAPER 1253

PLATE 15
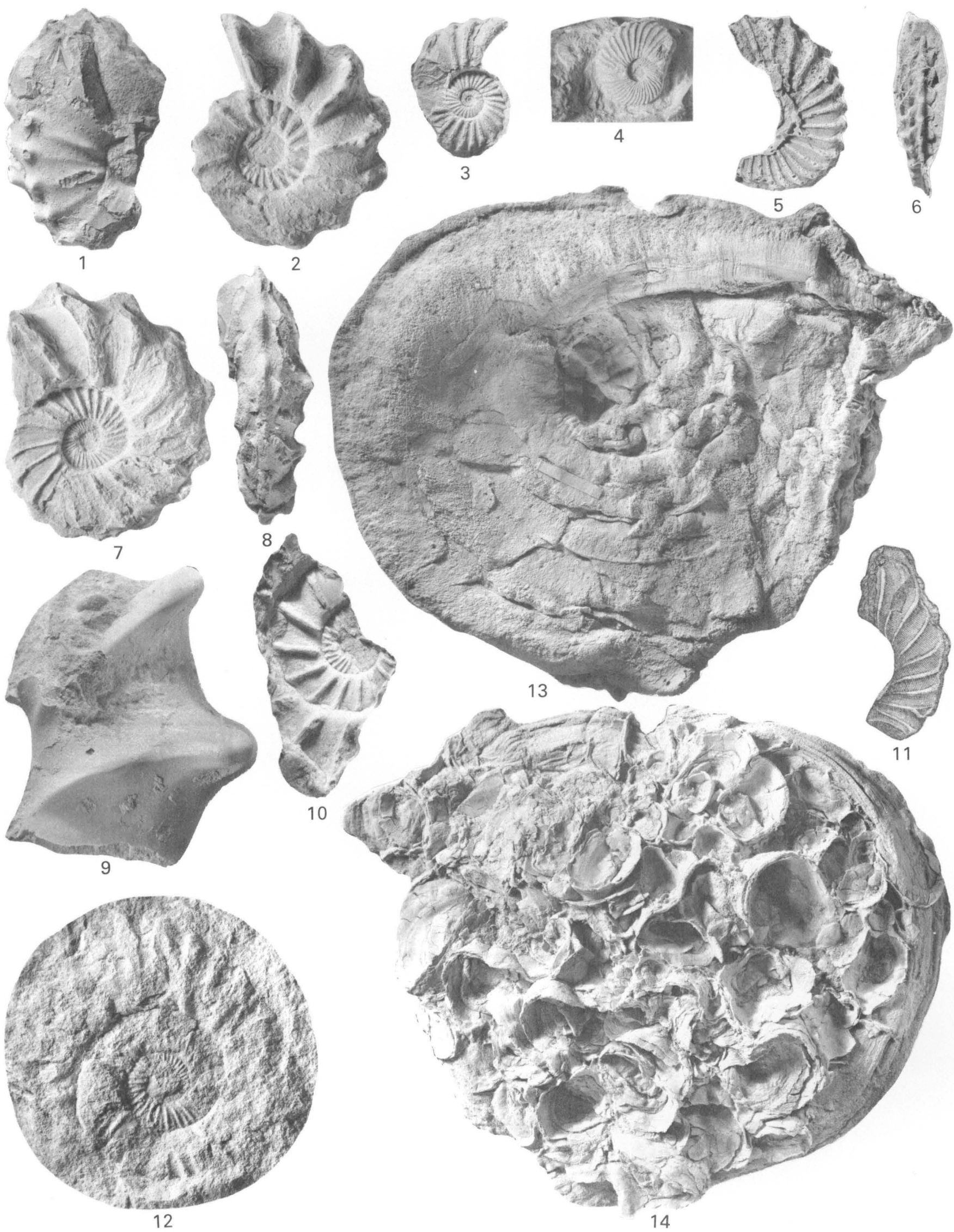

CENOMANIAN, TURONIAN, AND CONIACIAN MOLLUS KS 


\section{Lower Upper Cretaceous Strata in Minnesota and Adjacent Areas- Time-Stratigraphic Correlations and Structural Attitudes}

By E. A. MEREWETHER

STRATIGRAPHY AND PALEONTOLOGY OF MID-GRETACEOUS ROCKS I N M I NESOTA A N D C N T I G U US A R E A

GEOLOGICAL SURVEY PROFESSIONAL PAPER 1253-B

A summary of the regional stratigraphy and structure of mid-Cretaceous formations in the Minnesota region and a comparison of these strata with mid-Cretaceous rocks in Wyoming

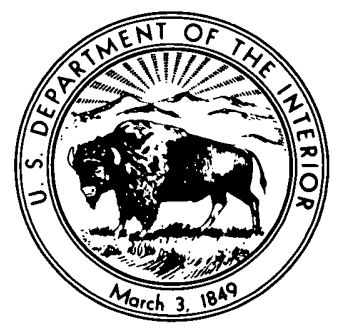





\section{CONTENTS}

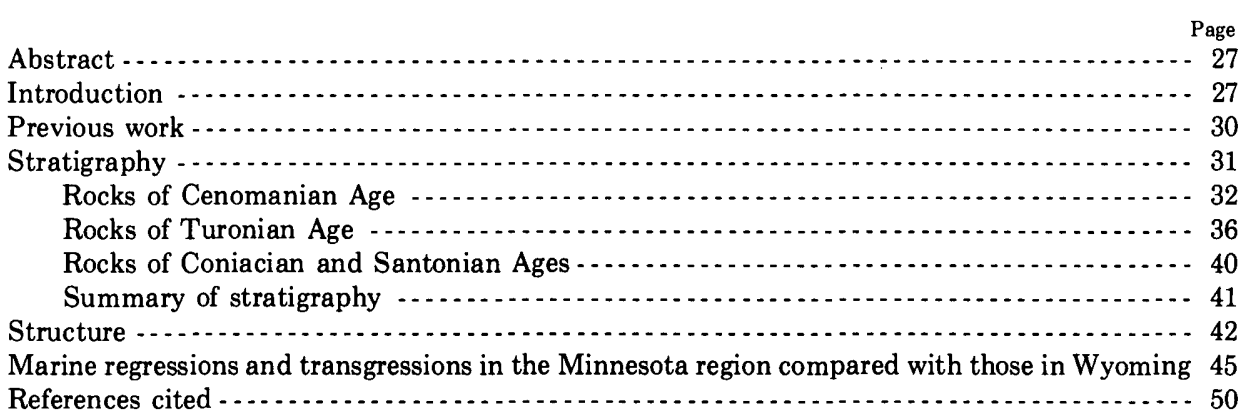

\section{ILLUSTRATIONS}

FiguRE 6. Map of the Minnesota region, showing locations of boreholes and outcrops used in

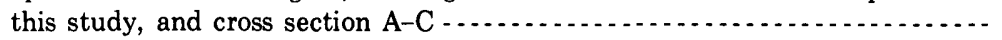

7. Correlation of the lower Upper Cretaceous formations at localities in north-

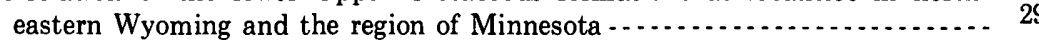
8-11. Photographs showing:

8. Irregular surface of Precambrian rocks in Dakota Granite Company's quarry ESE. of Milbank, S. Dak. . .

9. Uppermost Dakota Formation and overlying basal Graneros Shale on

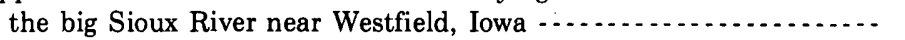

10. Upper Cretaceous strata in the Ochs Brick and Tile Company's claypit about $3 \mathrm{~km}$ southwest of Springfield, Minn. .........................

11. Upper part of Greenhorn Formation at outcrop northeast of Browns Valley, Minn.

12. Map showing approximate thickness of the Carlile Shale where overlain by the Niobrara Formation in the Minnesota region - . . . . . . . . . . . . . . 38

13. Photograph showing outcrop of Codell Sandstone Member of Carlile Shale, southeast of Mitchell, S. Dak. .....................

14. Photograph showing disconformable contact of Carlile Shale and overlying Niobrara Formation in northeastern Nebraska, west of Vermillion, S. Dak.-- 39

15. Map showing approximate distribution of land and sea in North America during Coniacian time ........................................... 42

16. Map showing structures at the top of the Greenhorn Formation in the Min-

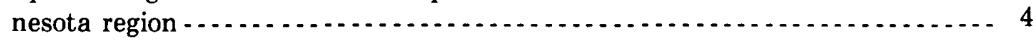

17. Cross section showing structure of Upper Cretaceous formations in northwestern Iowa, northeastern South Dakota, and Minnesota ........ . . . . . . . . . 44

18. Map of the Minnesota region and States of the central Rocky Mountains, showing locations of part of the Powder River Basin and the Transcontinental

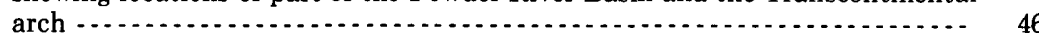

19. Correlation of the lower Upper Cretaceous formations at localities in the Min-

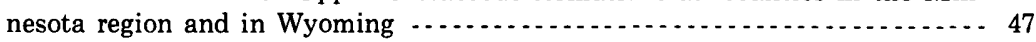

20. Diagram of marine transgressions and regressions of mid-Cretaceous age, interpreted from strata in the Minnesota region and in Wyoming . . . .

\section{TABLES}

Page

1. Boreholes in the Minnesota region $-\ldots \ldots \ldots \ldots \ldots$

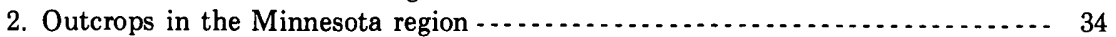



LOWER UPPER CRETACEOUS STRATA IN MINNESOTA AND ADJACENT AREAS-TIME-STRATIGRAPHIC CORRELATIONS AND STRUCTURAL ATTITUDES

\author{
By E. A. MEREWETHER
}

\section{ABSTRACT}

Sedimentary rocks of early Late Cretaceous age occur in the eastern parts of North Dakota, South Dakota, and Nebraska, and in Minnesota and western Iowa. They are generally included in, from oldest to youngest, the Dakota Formation, Graneros Shale, Greenhorn Formation, Carlile Shale, and Niobrara Formation. However, in eastern North Dakota, they are also assigned to, in ascending order, the Belle Fourche Shale, Greenhorn Formation, Carlile Shale, and Niobrara Formation. The Graneros Shale and laterally equivalent strata in the Belle Fourche Shale grade eastward into the Coleraine Formation of northeastern Minnesota and probably into the Windrow Formation of southeastern Minnesota. Cretaceous beds locally overlie rocks of Precambrian, Paleozoic, and Jurassic ages, and they are generally overlain by glacial drift and alluvium of Quaternary age. In Minnesota and adjoining areas, formations of mid-Cretaceous age commonly overlap the dissected surface of Precambrian rocks. The thickness of the lower Upper Cretaceous sequence ranges from about $223 \mathrm{~m}$ in eastern North Dakota and about $200 \mathrm{~m}$ in northeastern Nebraska to a featheredge in Minnesota and Iowa.

These lower Upper Cretaceous formations are composed mainly of shale, siltstone, sandstone, and limestone units of marine and nonmarine origin and were deposited near the eastern shore of a transgressing and regressing epicontinental sea in Cenomanian, Turonian, Coniacian, and Santonian time. During the late Cenomanian, the strandline was in Minnesota and was oriented generally northnortheast. Interpretations of the depositional environments of the strata and of fossils from outcrops and from clasts in glacial drift indicate that the Cretaceous seaway extended from this region northeastward across Canada to Greenland in the Turonian, Coniacian, and Santonian.

The Cretaceous formations are deformed into broad, shallow synclines in eastern North and South Dakota and in northeastern Nebraska. A west-trending anticline, the Sioux uplift, separates the synclines in southeastern South Dakota. Sparse evidence of minor faulting in the formations exists in northeastern South Dakota, along
\end{abstract}

the strike of a major southwest-trending zone of tectonism in the Precambrian basement rocks. The structural relief in the region, on the top of the Greenhorn Formation, is at least $250 \mathrm{~m}$ between eastern North Dakota and northeastern Minnesota, and at least $200 \mathrm{~m}$ between northeastern Nebraska and northwestern Iowa.

A comparison of the Cretaceous stratigraphy of the Minnesota region and of areas in Wyoming indicates that some marine transgressions and regressions were synchronous in the two regions. The transgression during Greenhorn time, the regression during early Carlile time, and the transgression during late Carlile and Niobrara time seem to be major events caused by either continent-wide tectonism or eustasy. Other regressions and transgressions in Wyoming and northern Utah were probably caused by local structural deformation and by changes in the source and supply of sediments during deposition.

\section{INTRODUCTION}

Sedimentary rocks of early Late Cretaceous age are present in eastern parts of North Dakota, South Dakota, Nebraska, and in Minnesota and western Iowa (fig. 6). These rocks consist mainly of sandstone, siltstone, shale, and limestone, and were deposited in marine and nonmarine environments near the eastern shore of the Cretaceous epicontinental sea.

The sequence of beds is as much as $223 \mathrm{~m}$ thick in eastern North Dakota (Bluemle, 1973, fig. 3) and about $200 \mathrm{~m}$ thick in northeastern Nebraska, but it thins eastward to a featheredge in Minnesota and Iowa. The basal strata of the Cretaceous sequence transgressively overlap an erosion surface of great relief, which slopes down westward from high areas in Minnesota (Sloan, 


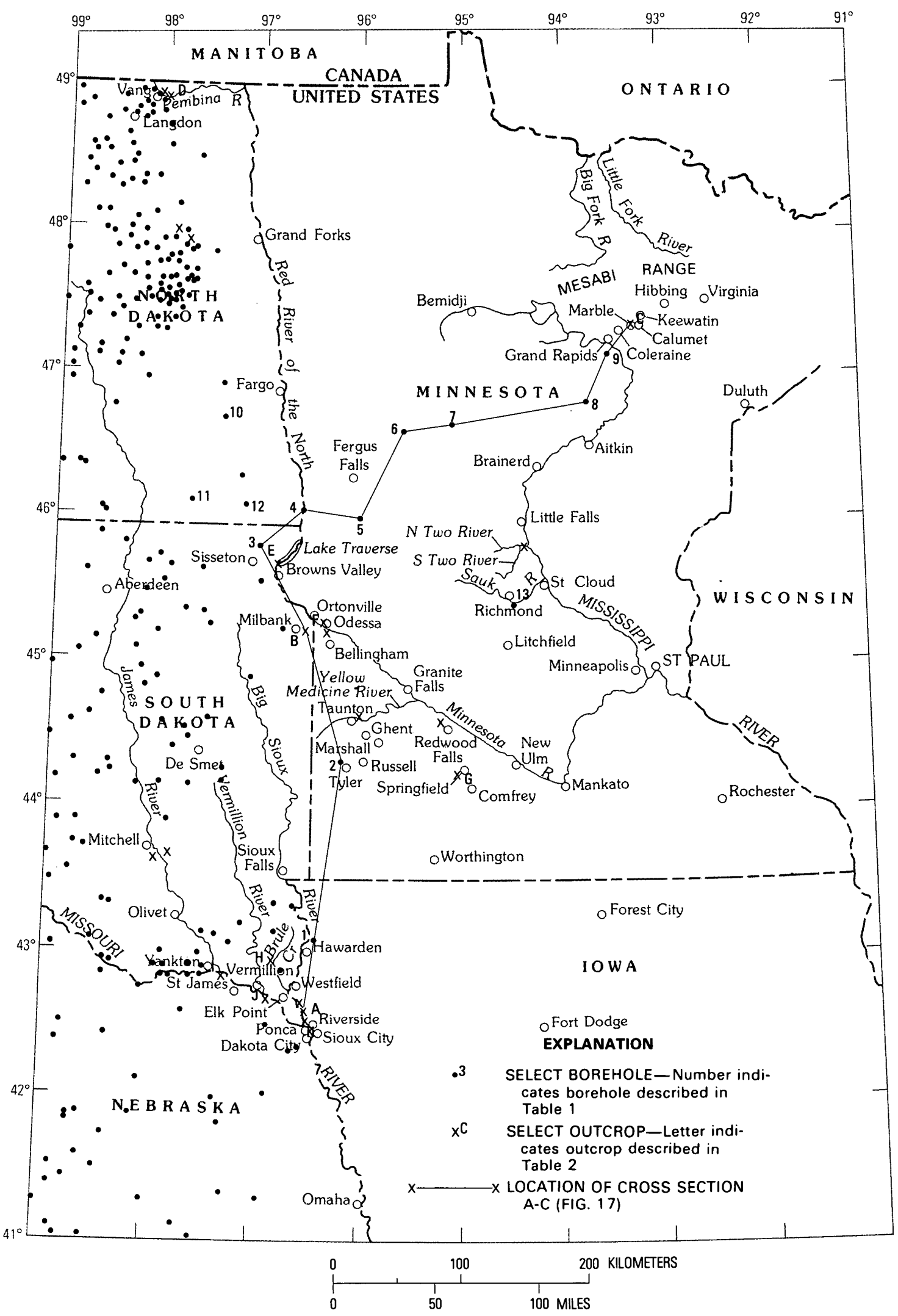

FIGURE 6.-Map of the Minnesota region, showing locations of boreholes and outcrops used in this study, and cross section A-C. 
1964, p. 5). Beds of early Late Cretaceous age in much of the Minnesota region were truncated and dissected by glacial and fluvial activity during the Pleistocene and are overlain by Quaternary sediments. These Cretaceous strata are usually assigned to, in ascending order, the Dakota Formation, Graneros Shale, Greenhorn Formation, Carlile Shale, and Niobrara Formation (fig. 7). However, the Dakota in some areas may be entirely of Early Cretaceous age.

This report is a compilation of the descriptions and interpretations of W. A. Cobban and the author, from field investigations and subsurface studies during 1977-79, and of the published and unpublished data of other workers. The purposes of this study are (1) to describe and interpret the lower Upper Cretaceous formations of the region, (2) to describe and interpret the structural attitudes of these strata, and (3) to compare the stratigraphy of the rocks in the Minnesota region, near the eastern shore of the Cretaceous sea, with the stratigraphy of rocks in Wyoming, near the western shore of the sea. Molluscan fossils from outcrops and boreholes in the Minnesota region were compared to the sequence of Western Interior index fossils (fig. 7) to determine the relative age of beds in the lower Upper Cretaceous for- mations. Many of the mollusks listed in figure 7 represent several genera with the same age span, and the listed species do not occur in every collection used in this investigation. The thicknesses of stratigraphic units, reported herein, have not been affected by postCretaceous erosion unless otherwise noted.

Several people have generously supplied unpublished data and interpretations which have been incorporated in the following pages. Doctor B. R. North and Professor W. G. E. Caldwell, University of Saskatchewan at Saskatoon, identified and interpreted specimens of Foraminifera in 20 samples from outcrops and cores. Palynomorphs in a sample of shale were described by $R$. H. Tschudy, of the U.S. Geological Survey. Fossils, borehole logs, and maps were provided by Professor G. W. Shurr, U.S. Geological Survey and St. Cloud State University, St. Cloud, Minn. Some of the molluscan index fossils, which were essential in correlating the Cretaceous strata, were collected by W. A. Cobban and R. E. Burkholder, U.S. Geological Survey; Cobban also identified all of the molluscan fossils in collections from the region. Cores of Cretaceous beds in eastern North Dakota were made available by S. B. Anderson, North Dakota Geological Survey, Grand Forks. Cores of strata

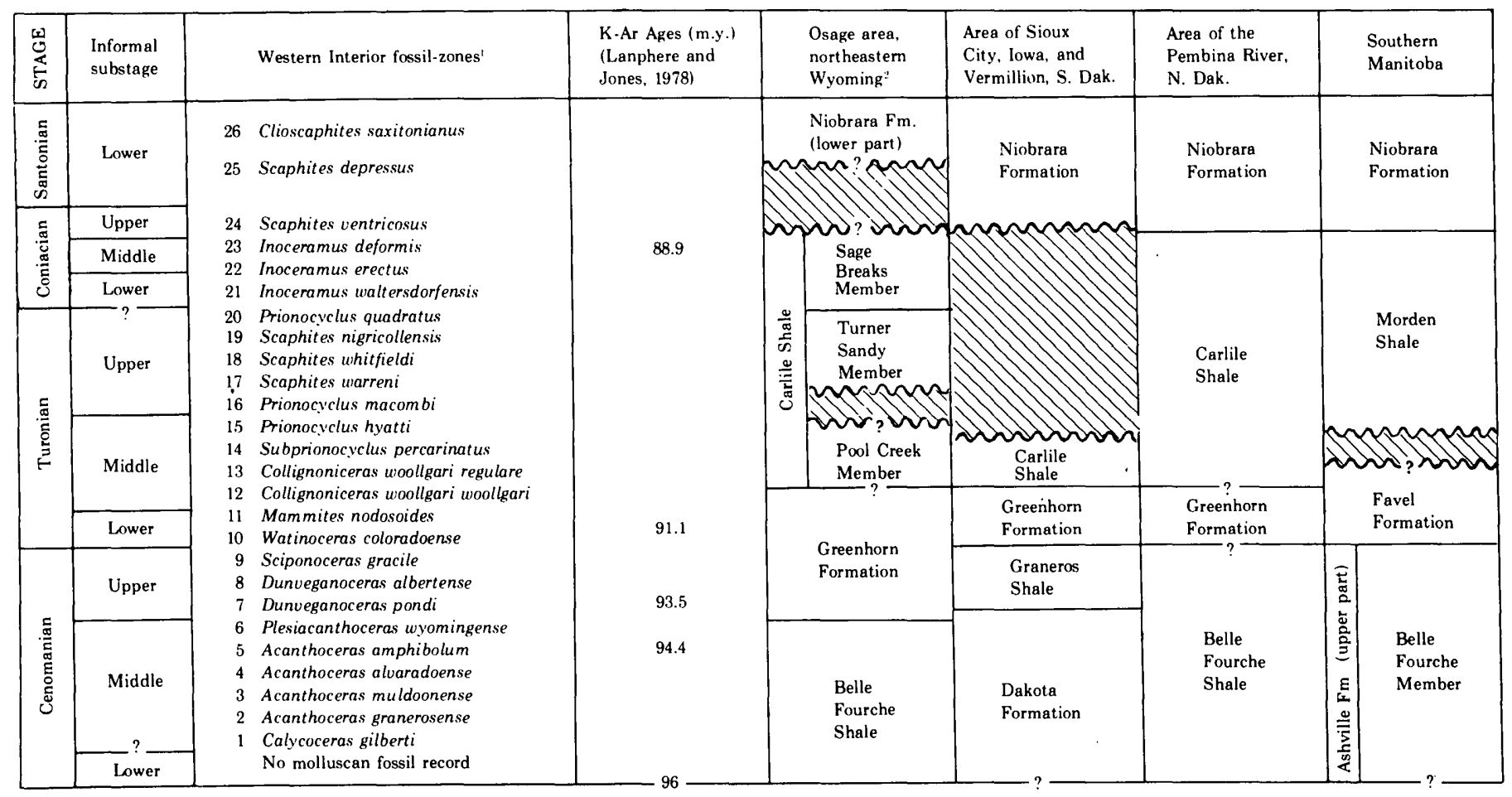

'Numbers representing some zones are shown in figure 17 and noted in text. ${ }^{2}$ Age of basal contact of Niobrara Formation from Evetts (1976, p. 121).

FiguRE 7.-Correlation of the lower Upper Cretaceous formations at localities in northeastern Wyoming and the region of Minnesota. Hiatus in sequence patterned. Age of contacts with queries is estimated. 
in northwestern Iowa were provided by G. A. Ludvigson and B. J. Bunker of the Iowa Geological Survey, Iowa City. G. E. Prichard, U.S. Geological Survey, generously supplied stratigraphic data from boreholes in northeastern Nebraska. The munificent assistance of these people is gratefully acknowledged.

\section{PREVIOUS WORK}

During the past 175 years, many distinguished scientists have investigated the sedimentary rocks of Cretaceous age in Minnesota and Iowa, and in the eastern parts of Nebraska, South Dakota, and North Dakota (fig. 6). Some of their contributions to the stratigraphy of the region are summarized in the following paragraphs.

Cretaceous strata typical of the region were observed by Meriwether Lewis and William Clark (Thwaites, 1904, v. 7) along the Missouri River between Omaha, Nebr., and Yankton, S. Dak. (fig. 6), during their expedition of 1804-06. In 1810, Thomas Nuttall (Nuttall, 1821) examined some of the outcrops and collected fossils in the same area. Specimens were also collected near the Missouri River by S. H. Long's party in 1819 . With the aid of molluscan fossils from these expeditions and Lardner Vanuxem's recognition (Morton, 1828) of Cretaceous beds in New Jersey, Morton (1834) assigned the outcropping rocks along the upper Missouri River to the Cretaceous.

Prince Maximillian von Wied Neuwied journeyed through the region in 1832 , collected important Cretaceous fossils, and published his observations in 1839-41. In 1839, J. N. Nicollet traveled up the Missouri River to Fort Pierre, S. Dak., examined outcrops that had been visited by Lewis and Clark, and then proceeded northeast to the Minnesota River. Nicollet (1841) identified Cretaceous limestone, marl, and clay along the Missouri River and obtained molluscan fossils, which were studied by Morton (1842). In 1849, John Evans examined the Cretaceous rocks near Sioux City, Iowa (fig. 6), and collected fossils, which were later described by D. D. Owen (Owen, 1852).

F. V. Hayden and F. B. Meek first visited the upper Missouri River region in 1853 to gather fossils for James Hall. Data from their survey, which were presented by Hall and Meek (1856), included a composite section of the Cretaceous strata along the Missouri River between Fort Pierre, S. Dak., and Omaha, Nebr. Fossil leaves collected by Hayden from the basal sandstone of the sequence were assigned to the Miocene by Heer (1859) and reassigned to the Cretaceous by Newberry (1860). Meek and Hayden (1862) named the lithologic units in their section, from oldest to youngest, as follows: "Dakota group" (mainly sandstone, $122 \mathrm{~m}$ thick), "Fort Benton group" (mainly clay, $244 \mathrm{~m}$ thick), "Niobrara division" (marl and limestone, $61 \mathrm{~m}$ thick), "Fort Pierre group" (clay, $213 \mathrm{~m}$ thick), and "Fox Hills beds" (sandstone and clay, $152 \mathrm{~m}$ thick). Marcou and Capellini studied the "Dakota group" near Sioux City, Iowa, in 1863 and concluded that the sandstone unit was of Cretaceous age and of freshwater origin (Marcou, 1864). Meek disagreed with Marcou and subsequently stated (Meek, 1865) that those rocks had been deposited in the brackish and normally saline waters of a bay or an estuary. The Cretaceous age of the Dakota along the Missouri River was later confirmed by Capellini and Heer (1866) and by Lesquereux (1868) from collections of fossil leaves.

In 1870 , White summarized the geology of Iowa and proposed that the Cretaceous strata be named, from oldest to youngest, "Nishnabotna sandstone, Woodbury sandstones and shales, and Inoceramus beds." White's Woodbury included the Dakota and Fort Benton of Meek and Hayden (1862); however, his nomenclature has since been abandoned. Rocks of Cretaceous age in Minnesota were first reported by Kloos (1872), who obtained molluscan fossils from clay and shale in a well near Richmond (fig. 6). Meek identified the fossils and concluded that the clay and shale were within the "Benton group." By 1878, Winchell had determined that Cretaceous beds underlie the glacial drift in most of western Minnesota.

The Fort Benton, Niobrara, and Fort Pierre strata of Meek and Hayden (1862) were later included in the "Colorado group" by Hayden (1876) and by King (1876). These rocks are underlain by their "Dakota group" and overlain by their "Fox Hills group." However, in 1893, Calvin published a section of the outcropping Cretaceous strata near Sioux City, Iowa, which he assigned to the "Dakota group" (32 m thick), "Fort Benton group" (12 m), and "Niobrara group" (9 m). Calvin (1893, p. 11) believed that the lower part of the Dakota had accumulated in brackish water and that the Fort Benton was deposited in "a clear open sea."

The Cretaceous rocks of eastern South Dakota were described and interpreted in 1894 by Todd, whose stratigraphic nomenclature was essentially that of Meek and Hayden (1862). Todd applied the names Dakota Formation, Colorado Formation (including the Fort Benton, Niobrara, and Fort Pierre "sub-formations"), and Fox Hills Group. In a description of the geology near Sioux City, Iowa, Bain (1896) summarized the early reports and divided the Cretaceous sequence into the "Dakota formation" and the "Colorado formation." His Colorado consisted of the Fort Benton or Benton and the Niobrara. Later, after mapping outcrops near Mitchell, S. Dak. (fig. 6), Todd (1903) discovered that a sandstone that had been assigned to the Dakota Formation was younger than the Dakota and belonged in the upper part of the Benton Formation (the name Fort Benton was 
abandoned). As a consequence, Todd (1904) revised the Cretaceous stratigraphy and the stratigraphic terminology of the region. His nomenclature for the Elk Point quadrangle of South Dakota, Nebraska, and Iowa (Todd, 1908) includes, from oldest to youngest: Dakota Sandstone (107-122 m thick), Graneros Shale (20-32 m), Greenhorn Limestone (about $9 \mathrm{~m}$ ), Carlile Shale (61-66 $\mathrm{m}$ ), and Niobrara Formation (more than $61 \mathrm{~m}$ ). The Graneros, Greenhorn, and Carlile are formations of the Benton Group. These names were also applied in Darton's (1909) description of the geology of South Dakota and have been used in many reports concerning the region since that time. Tester (1931) provided an excellent review of the geologic literature with a detailed description of the Dakota Sandstone near Sioux City, Iowa. More recently, the Dakota Formation of South Dakota was studied and described by Schoon (1965, 1971). Agnew and Tychsen (1965) summarized the stratigraphic nomenclature and other pertinent information for mid-Cretaceous rocks in South Dakota.

In south-central Minnesota, Cretaceous rocks of marine and continental origin were formerly named the Big Cottonwood Formation by Sardeson (1908). The scattered bodies of Cretaceous strata in southeastern Minnesota were named the Ostrander Member of the Dakota Formation by Stauffer and Thiel (1941, p. 103) and were later included in the Windrow Formation of Thwaites and Twenhofel (1921) by Andrews (1958). The Windrow of Andrews (1958) consists of the Iron Hill Member, an iron-rich regolith on rocks of pre-Cretaceous age, and the overlying East Bluff Member, which is composed of conglomerate, sandstone, and shale of nonmarine origin. Austin $(1963$, p. 3) and Sloan $(1964$, p. 17-19) accepted most of Andrew's terminology but used the name Ostrander Member instead of East Bluff Member. The Cretaceous beds in south-central Minnesota were assigned by Parham (1970) to three informal stratigraphic units which, from oldest to youngest, consist of (1) kaolinitic residuum of Cretaceous age, (2) kaolinitic sandstone and clay of Late Cretaceous age; and (3) kaolinitic clay and overlying illitic and montmorillonitic strata of Late Cretaceous age. Parham $(1970$, p. 7) also reported that the contacts of his units are unconformities. In southwestern Minnesota, Austin (1972, fig. 5) recognized, in ascending order, residuum of Early and Late Cretaceous age, and the Dakota Formation, Graneros Shale, Greenhorn equivalent, Carlile Shale, Niobrara equivalent, and possibly the Pierre Shale of Late Cretaceous age. He also summarized the relative ages of the Cretaceous stratigraphic units in Minnesota.

In northeastern Minnesota, conglomerate, sandstone, and shale of Cretaceous age locally mantle the irregular surface of Precambrian igneous and metamorphic rocks. White (1893) assigned these strata to the "Colorado series" and listed a few fossils from the beds. The sequence was formerly well exposed in open-pit mines between the towns of Coleraine and Virginia and was named the Coleraine Formation by Stauffer and Thiel (1941, p. 99). Bergquist (1944, p. 8) reported that the Coleraine was locally more than $30 \mathrm{~m}$ thick and that the formation was of marine origin at the western outcrops and largely of continental origin at the eastern outcrops. $\mathrm{He}$ also suggested that the formation was the same age as beds in the lower part of the Benton.

In eastern North Dakota, the Cretaceous strata are commonly assigned to, from oldest to youngest: the Dakota Group, Colorado Group, and Montana Group (Hansen and Kume, 1970, p. 14-17; Arndt, 1975, fig. 2). In much of that area, the Colorado Group includes, in ascending order, the Belle Fourche Shale, Greenhorn Formation, Carlile Shale, and Niobrara Formation.

\section{STRATIGRAPHY}

The Upper Cretaceous rocks in the Minnesota region consist of sandstone, siltstone, shale, limestone, and minor conglomerate, lignite, and bentonite, and are as much as $329 \mathrm{~m}$ thick in northeastern North Dakota (Bluemle, 1973, fig. 3). These strata, which were deposited in marine and continental environments near the eastern shore of the shallow epicontinental sea, are generally assigned to, in ascending order, the Dakota Formation, Graneros Shale, Greenhorn Formation, Carlile Shale, Niobrara Formation, and Pierre Shale (fig. 7). However, in eastern North Dakota the rocks are included in the Colorado Group and the overlying Montana Group (Hansen and Kume, 1970, p. 14-17); and the Colorado Group is composed of, from oldest to youngest, the Belle Fourche Shale, Greenhorn Formation, Carlile Shale, and Niobrara Formation. Laterally equivalent strata in southern. Manitoba are assigned to, in ascending order, the Belle Fourche Member of the Ashville Formation, Favel Formation, Morden Shale, Niobrara Formation, and Pierre Shale (McNeil and Caldwell, 1981). The Pierre Shale, which was described by Gill and Cobban (1965), and other formations of the Montana Group are not treated herein. In Minnesota, Cretaceous units are named Windrow Formation (Andrews, 1958) in the southeastern part of the State, and Coleraine Formation (Stauffer and Thiel, 1941, p. 99) in the northeastern part of the State.

In most of the Minnesota region, the Cretaceous sequence is unconformably overlain by glacial deposits of Pleistocene age and by alluvium of Holocene age. The sequence unconformably overlies rocks as young as Jurassic, in eastern North Dakota (Hansen and Kume, 1970, fig. 4), and as old as early Precambrian in western Minnesota (Sloan, 1964, fig. 2). The Cretaceous strata ac- 


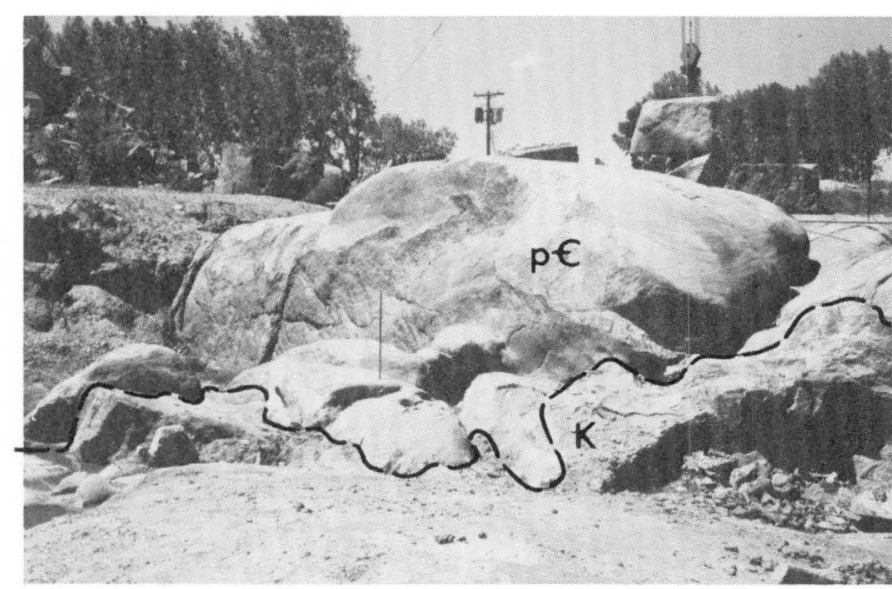

F IGURE 8.--Irregular surface of Precambrian rocks (local relief about 4 m) in Dakota Granite Company's quarry about $9.1 \mathrm{~km}$ ESE. of Milbank, S. Dak. (SW $1 \frac{1}{4}$ sec. 18, T. 120 N., R. 47 W., Grant County). Dashed line, contact of Precambrian ( $\mathrm{p} €$ ) and midCretaceous $(\mathrm{K})$ rocks.

cumulated by onlap on an irregular erosional surface (fig. 8), which sloped generally down to the west and had as much as $430 \mathrm{~m}$ of regional relief (Sloan, 1964, p. 5). The strata are locally nearly horizontal; consequently, the basal beds in the sequence vary greatly in age, being oldest in the channels and other low areas of the erosion surface in the western part of the region.

\section{ROCKS OF CENOMANIAN AGE}

In much of the Minnesota region (fig. 6), strata of Cenomanian age are the upper part of the Dakota Formation and the overlying Graneros Shale (fig. 7). However, in eastern North Dakota, Cenomanian beds are assigned to the Belle Fourche Shale, which is underlain by the Newcastle Sandstone (Hansen and Kume, 1970, p. 14) or the Mowry Shale (Bluemle, 1973, p. 11). At outcrops in western South Dakota, the Newcastle and Mowry are of Early Cretaceous (pre-Cenomanian) age. Near the Missouri and Big Sioux Rivers, the Dakota Formation is as much as $140 \mathrm{~m}$ thick and is composed mainly of sandstone interbedded with siltstone, shale, and minor lignite (Darton, 1909, p. 46; Simpson, 1960, p. 16; Schoon, 1971, fig. 1). At outcrops, the sandstone is commonly light brownish gray, very fine grained to medium grained, and cross stratified; it contains carbonaceous material, root casts, fossil leaves, and nonmarine pelecypods (fig. 9). Some of the shale in the Dakota at Sioux City, Iowa, is silty and contains burrows. Tester (1931, p. 280-281) concluded that the formation in the type area, around Dakota City, Nebr., had been deposited in nonmarine and marine environments near the shoreline of a shallow sea.

Similar rocks were encountered in borehole 1 (table 1) near Hawarden, Iowa (fig. 6), where the Dakota is about $127 \mathrm{~m}$ thick and unconformably overlies strata of Devonian age (Ludvigson and Bunker, 1978). The thickness of the Dakota in eastern South Dakota commonly ranges from 15 to $140 \mathrm{~m}$ (Schoon, 1971, fig. 1). In northeastern South Dakota and in the adjacent part of Minnesota, the formation is locally missing because of relief on the surface of the underlying Precambrian rocks. However, in borehole 3 (table 1) near Sisseton, S. Dak. (fig. 6), the Dakota Formation is about $44 \mathrm{~m}$ thick (Merewether and Gray, 1978, p. 9).

Baker (1967, p. 17) reported that the Dakota in southeastern North Dakota thickens generally westward from a featheredge to more than $73 \mathrm{~m}$. Cores of Cretaceous strata in eastern North Dakota include a basal unit of interstratified sandstone, siltstone, and shale, which Moore $(1979$, p. 122, 156) referred to as "basal Cretaceous clastics." Marine rocks within this sequence, at boreholes 10 and 11 (fig. 6; table 1), contain Foraminifera of Albian or Cenomanian Age (B. R. North and W. G. E. Caldwell, written commun., 1979). The unit of "basal Cretaceous clastics," which would traditionally be assigned to the Dakota, is probably of Early Cretaceous age and is as much as $87 \mathrm{~m}$ thick in boreholes in northeastern North Dakota (Moore, 1979, p. 229).

In central Minnesota, at the confluence of the Two River and the Mississippi River, outcrops of interbedded clay, shale, sandstone, and lignite were reported by Upham (1888, p. 601-603) and Allison (1932, p. 131), and assigned to the Dakota Formation by Stauffer and Thiel (1941, p. 175). Fossil pelecypods of fresh-water origin collected at this locality by Upham (1888, p. 602), were also found in the Dakota Formation near Dakota City in northeastern Nebraska and near Fairbury in southeastern Nebraska.

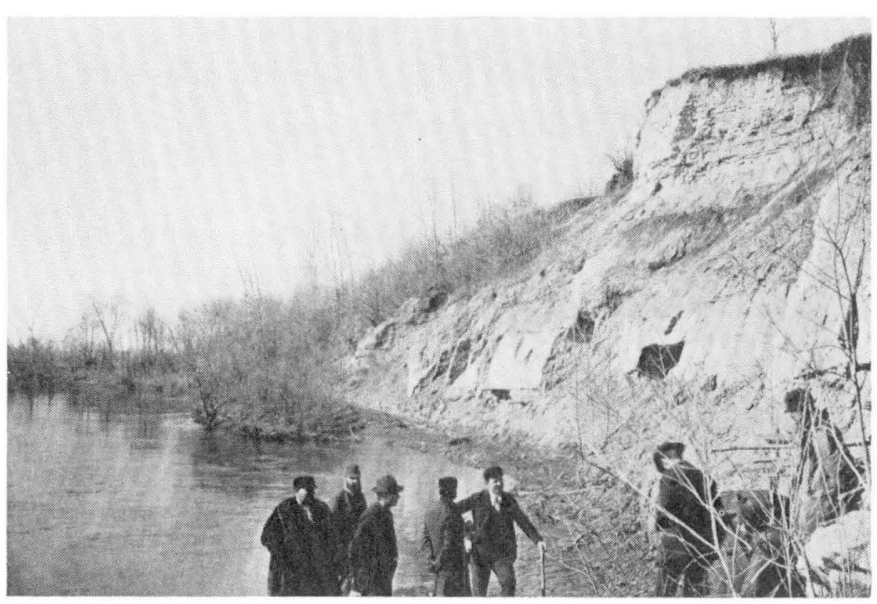

FIGURE 9.-Uppermost Dakota Formation and overlying basal Graneros Shale on the Big Sioux River near Westfield, Iowa (Bain, 1895). 
T ABLE 1.-Boreholes in the Minnesota region (fig. 6)

\begin{tabular}{|c|c|c|c|c|c|}
\hline \multirow[b]{2}{*}{ Borehole } & \multirow[b]{2}{*}{ Driller } & \multirow[b]{2}{*}{ Name } & \multicolumn{3}{|c|}{ Location } \\
\hline & & & Section & $\begin{array}{l}\text { Township } \\
\text { (North) }\end{array}$ & $\begin{array}{l}\text { Range } \\
\text { (West) }\end{array}$ \\
\hline 1 & $\begin{array}{l}\text { Iowa Geological Survey- } \\
\text { U.S. Geological } \\
\text { Survey. }\end{array}$ & Test D-7 $\ldots \ldots$ Iowa $\ldots \ldots$ & 5 & 95 & 47 \\
\hline 2 & U.S. Geological Survey & Couteau No. 2 - Minnesota - - . - & 33 & 110 & 44 \\
\hline 3 & $\begin{array}{l}\text { Wismers Well } \\
\text { Drilling Co. }\end{array}$ & Ruben Slather - South Dakota - & 18 & 127 & 50 \\
\hline 4 & $\begin{array}{l}\text { Unknown (Maclay and } \\
\text { others, 1968). }\end{array}$ & Unknown .... Minnesota .... & 22 & 130 & 47 \\
\hline 5 & - do - do & $\begin{array}{l}\text { Elbow Lake Test - - do - } \\
\text { hole. }\end{array}$ & 8 & 129 & 42 \\
\hline 6 & $\begin{array}{l}\text { Unknown (Winter and } \\
\text { others, 1969). }\end{array}$ & Perham well $\ldots .$. do $\ldots . . .$. & 14 & 136 & 39 \\
\hline 7 & $\begin{array}{l}\text { Unknown (Lindholm and } \\
\text { others, 1972). }\end{array}$ & Sebeka well $\ldots$... - do - . - . & 34 & 137 & 35 \\
\hline 8 & $\begin{array}{l}\text { Unknown (Bolin, 1956; } \\
\text { Sloan, 1964, fig. 5). }\end{array}$ & Unknown $\ldots . .-$ do & 23 & 50 & 27 \\
\hline 9 & $\begin{array}{l}\text { U.S. Geological Survey } \\
\text { (Oakes, 1970). }\end{array}$ & Unknown - ... - - do ....... & 27 & 54 & 25 \\
\hline 10 & U.S. Dept. of Energy & RRVD 7 .... North Dakota - & 23 & 137 & 53 \\
\hline 11 & - do & RRVD $1 \ldots \ldots$ do $\ldots \ldots$ & 11 & 130 & 56 \\
\hline 12 & 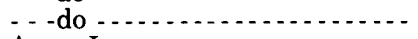 & RRVD $2 \ldots . .$. do $\ldots$ & 19 & 130 & 51 \\
\hline 13 & Amax Inc. & Core 9 . & 4 & 122 & 30 \\
\hline
\end{tabular}

In southern Minnesota, a weathering residuum of Early and Late Cretaceous age (Austin, 1970) overlies Precambrian and Paleozoic rocks and is unconformably overlain by nonmarine and marine strata (Sloan, 1964; Parham, 1970), which Austin (1972, fig. 5) interpreted as mid-Cenomanian and correlated with the Dakota Formation. However, beds near Springfield, in southcentral Minnesota, contain fossils probably of late Cenomanian age; consequently, the rocks are described in the following paragraphs.

The Graneros Shale is conformable and gradational with the underlying Dakota Formation. In the vicinity of Yankton, S. Dak. (fig. 6), the Graneros is as much as 50 $\mathrm{m}$ thick and consists mainly of dark-gray shale (Condra, 1908, p. 11; Simpson, 1960, p. 18). Locally, the Graneros is sandy at the base and calcareous at the top (Todd, 1908, p. 2). Outcrops near Ponca, Nebr., are composed of flaser-like beds of calcareous siltstone and lesser amounts of shale, which contain small burrows parallel to the bedding. At Sioux City, Iowa, some outcrops of the basal Graneros (table 2, outcrop $\mathrm{K}$ ) display interference ripples, scour marks, and small burrows, including Arenicolites. Except for some of the lowermost beds, the Graneros was deposited in offshore-marine environments. Molluscan fossils of marine origin, which have been collected from the lower part of the formation in the vicinity of Sioux City, include Dunveganoceras pondi Haas and Inoceramus prefragilis stephensoni Kauffman and Powell of late Cenomanian age (fig. 7, zone 7). At outcrops along the Big Sioux River and in borehole 1 (table 1) near Hawarden, Iowa (Ludvigson and Bunker, 1978; this report, fig. 6), the upper part of the Graneros contains Inoceramus ginterensis Pergament of late
Cenomanian age, from the zone of Dunveganoceras albertense (Warren) (fig. 7, zone 8).

Sparse outcrops of shale near the town of Mitchell, in southeastern South Dakota (fig. 6), contain palynomorphs of Albian or Cenomanian Age (R. H. Tschudy, written commun., 1979) and ammonites of indeterminate age. These rocks could be glacial erratics and are probably part of the Graneros Shale. Where penetrated by boreholes in the vicinity of De Smet, S. Dak. (fig. 6), the formation is as much as $69 \mathrm{~m}$ thick (Bolin and Petsch, 1954, p. 84). At borehole 2 near Tyler, Minn., the Graneros is about $25 \mathrm{~m}$ thick and consists of fossiliferous, noncalcareous shale and minor sandstone (C. R. Collier and H. R. Bergquist, written commun., 1969). In northeastern South Dakota in the vicinity of Aberdeen, the formation is as much as $88 \mathrm{~m}$ thick (Koch and Bradford, 1976, table 4). Near Sisseton, S. Dak., in borehole 3 (fig. 6), the formation is about $58 \mathrm{~m}$ thick (Merewether and Gray, 1978, p. 9). The Graneros Shale of eastern South Dakota becomes the upper part of the Belle Fourche Shale in eastern North Dakota (Hansen and Kume, 1970, fig. 4). Boreholes 11 and 12 (table 1), in southeastern North Dakota, penetrated $67-80 \mathrm{~m}$ of shale and siltstone which Moore $(1979$, p. 122, 129) included in the Belle Fourche. Bluemle (1973, fig. 3) reported as much as $76 \mathrm{~m}$ of Belle Fourche in northeastern North Dakota.

The Cenomanian beds assigned to the Dakota and Graneros near Sioux City, Iowa, are represented in southern Manitoba by marine noncalcareous shale, which was assigned to the Belle Fourche Member of the Ashville Formation by McNeil and Caldwell (1981; this report, fig. 7). Foraminifera in these rocks were cor- 
T ABLE 2.-Outcrops in the Minnesota region (fig. 6)

\begin{tabular}{|c|c|c|c|c|c|c|}
\hline \multirow[b]{2}{*}{ Outcrop } & \multirow[b]{2}{*}{ Unit } & \multirow[b]{2}{*}{ Area } & \multirow[b]{2}{*}{ State } & \multicolumn{3}{|c|}{ Location } \\
\hline & & & & Section & $\begin{array}{c}\text { Township } \\
\text { (North) }\end{array}$ & Range \\
\hline $\mathrm{A}$ & $\begin{array}{l}\text { Graneros Shale } \\
\text { and Greenhorn } \\
\text { Formation. }\end{array}$ & $\begin{array}{l}\text { Stone State Park } \\
\text { near Sioux City. }\end{array}$ & Iowa $\ldots \ldots \ldots$ & 26 & 90 & $48 \mathrm{~W}$. \\
\hline B & Carlile Shale ......... & $\begin{array}{l}\text { Dakota Granite Co. } \\
\text { quarry near Milbank. }\end{array}$ & South Dakota & 18 & 120 & $47 \mathrm{~W}$. \\
\hline $\mathrm{C}$ & Coleraine Formation .... & $\begin{array}{l}\text { Hill-Annex mine, } \\
\text { Mesabi Range. }\end{array}$ & Minnesota .... & 16 & 56 & $23 \mathrm{~W}$. \\
\hline $\mathrm{D}$ & $\begin{array}{l}\text { Carlile Shale } \\
\text { and Niobrara } \\
\text { Formation. }\end{array}$ & Pembina River - . & North Dakota & 34 & 163 & $57 \mathrm{~W}$. \\
\hline $\mathrm{E}$ & $\begin{array}{l}\text { Greenhorn Formation } \\
\text { and Carlile Shale. }\end{array}$ & Browns Valley - & Minnesota - . - & 2 & 125 & $49 \mathrm{~W}$. \\
\hline F & Greenhorn Formation - - - & Quarry near Odessa - .......... & - do $\quad . . . .$. & 32 & 121 & $45 \mathrm{~W}$. \\
\hline $\mathrm{G}$ & Windrow Formation & $\begin{array}{l}\text { Och's claypit near } \\
\text { Springfield. }\end{array}$ & -- do $---\ldots$ & 26 & 109 & $35 \mathrm{~W}$. \\
\hline $\mathrm{H}$ & Carlile Shale - . . . . & $\begin{array}{l}\text { Union County State } \\
\text { Park near Vermillion. }\end{array}$ & South Dakota & 29 & 94 & $50 \mathrm{~W}$. \\
\hline I & Niobrara Formation -.... & $\begin{array}{l}\text { Near confluence of James } \\
\text { River and Missouri River. }\end{array}$ & Nebraska -.... - & 24 & 33 & $1 \mathrm{E}$. \\
\hline$J$ & Carlile Shale $-\ldots . . .$. & $\begin{array}{l}\text { Near Missouri River } \\
\text { and Vermillion, S. Dak. }\end{array}$ & -- do $\cdots-$. & 3 & 31 & $5 \mathrm{E}$. \\
\hline $\mathrm{K}$ & Graneros Shale -...... & Sioux City & Iowa $\ldots \ldots$ & 14 & 89 & $48 \mathrm{~W}$. \\
\hline
\end{tabular}

related with a succession of Cenomanian ammonites, including Dunveganoceras albertense (Warren) (fig. 7), by Caldwell and others (1978, table 1).

Marine and nonmarine fossils of late Cenomanian age, representing the zone of Dunveganoceras albertense (Warren) (fig. 7, zone 8), have been collected from the Coleraine Formation in iron mines of the Mesabi Range (table 2, outcrop C), in northeastern Minnesota (Bergquist, 1944; this report, fig. 6). The Coleraine in that area was reported to be more than $30 \mathrm{~m}$ thick. Most of the formation in the mines has been excavated, but it formerly consisted of a basal conglomerate overlain by sandstone and shale. These rocks contained fossilized mollusks, arthopods, fish teeth, reptile bones, and plant debris (Stauffer and Thiel, 1941, p. 106) and represented deposition in shallow-marine environments, in the western part of the Mesabi Range, and in nonmarine environments, in the eastern part of the range (Bergquist, 1944 , p. 8). In northwestern Iowa, marine fossils of the same age occur in the upper part of the Graneros Shale. Pierce (1961) reported that the Coleraine near the town of Virginia, Minn., contains palynomorphs of probable Cenomanian Age. Cretaceous shale and sandstone were also encountered in boreholes located between the towns of Grand Rapids and Aitkin, southwest of the Mesabi Range (fig. 6). These beds are of nearshore, shallowmarine or brackish-water origin and contain Foraminifera that are probably of Cenomanian Age (Bolin, 1956, p. 284-285).

The Windrow Formation in southeastern Minnesota is at least $21 \mathrm{~m}$ thick (Austin, 1963, table 1) and consists of a basal ferruginous regolith (Iron Hill Member) and overlying poorly indurated clay, sandstone, and conglomerate (Ostrander Member) (Austin, 1963, p. 9; Sloan, 1964, p. 18). From paleontologic and stratigraphic data, Austin (1972, fig. 5) concluded that the Iron Hill Member is of Early Cretaceous and early Cenomanian age and that the Ostrander Member is of late Cenomanian age and, possibly, of Turonian, Coniacian, and Santonian Ages. These strata were deposited in nonmarine environments and are locally overlain by marine beds that contain shark teeth and Ophiomorpha (Austin, 1972 , p. 61). The Windrow grades westward into an unnamed sequence of nonmarine and marine beds.

In south-central Minnesota, the Cretaceous sequence was divided by Parham (1970) into three stratigraphic units, which consist of, in ascending order: (1) kaolinitic residuum, (2) kaolinitic sandstone and kaolinitic clay, and (3) kaolinitic clay and overlying illitic and montmorillonitic beds. The contacts of these units are unconformities (Parham, 1970, p. 7).

In the vicinity of New Ulm, Minn. (fig. 6), the Cretaceous sequence is at least $60 \mathrm{~m}$ thick and is composed of interstratified red, gray, and green shale and siltstone, gray and yellow sandstone, and thin beds of nodular limestone (Thiel, 1944, p. 121; Sloan, 1964, p. 20-21; Austin, 1970, p. 187). The sandstone is fine grained to coarse grained, locally pebbly and friable, and is either horizontally stratified, planar crossbedded, or trough crossbedded. Sloan $(1964$, p. 21) reported that the "direction of sediment transport $* * *$ is almost due west." Most of these rocks were deposited in nonmarine environments, although a few outcrops display vertical burrows and are probably of marine origin. Lesquereux 
(1895) assigned some of these strata to the "Dakota group" and related them to the Cenomanian through studies of fossil leaves. Pierce (1961) sampled outcrops of Cretaceous rocks near New Ulm, Redwood Falls, and Richmond, Minn. (fig. 6), and reported that the palynomorphs in the sampled beds are of Cenomanian Age. He also concluded that during the early Late Cretaceous, south-central Minnesota had little topographic relief (probably less than $150 \mathrm{~m}$ ) and had a warm temperate climate similar to the climate of rain forests in the Pacific Northwest. Later investigations by Austin (1970, p. 193) of the rocks at New Ulm determined that the basal regolith probably "is no younger than early Cenomanian" and that differences in the clay mineralogy of the overlying beds are evidence of a climatic change during the Cenomanian-from humid tropical to temperate. Austin (1972, fig. 5) also proposed that these rocks and others in the Minnesota River Valley are of Early and Late Cretaceous age. Parham's (1970) residuum is of Early Cretaceous and early Cenomanian age, and the overlying units of strata are about middle Cenomanian (Austin, 1972, fig. 5).

Sloan (1964, p. 21) reported that the Cretaceous sequence in the vicinity of Springfield, Minn. (fig. 6), is mainly light gray shale and is at least $61 \mathrm{~m}$ thick. In the Ochs Brick and Tile Company's new claypit near Springfield (table 2, outcrop G), the Cretaceous rocks consist of a unit of siltstone and interlaminated siltstone and shale about $7.6 \mathrm{~m}$ thick, and an overlying unit of shale, siltstone, and minor sandstone and lignite about 6.9 m thick (Sloan, 1964, p. 22). The basal unit (fig. 10) contains sparse burrows and trochamminid Foraminifera (B. R. North and W. G. E. Caldwell, written commun., 1979). Ferruginous concretionary beds in the upper unit contain fossil wood with borings, burrows, fish bones, shark teeth, and molluscan fossils of nearshoremarine and brackish-water origin. The mollusks include Anatimya plicata Bergquist, a marine bivalve also found in upper Cenomanian beds of the Coleraine Formation in the Mesabi Range. A single specimen of the late Cenomanian ammonite Dunveganoceras albertense (Warren) (fig. 7, zone 8), was obtained from red shale in an excavation in the town of Comfrey, Minn., about 17 $\mathrm{km}$ southeast of Springfield. This red shale resembles beds in the sequence at New Ulm and was "probably derived from the Sioux Quartzite" in the area (Sloan, 1964 , p. 27). However, the fossil could have been transported by glacial activity and, therefore, may not reflect the age of the local strata. Nevertheless, some of the Cretaceous rocks near Springfield probably are of late Cenomanian age (fig. 7, zone 8); these would be shallowmarine and nonmarine facies of the Graneros Shale. A core from borehole 2 near Tyler, in southwestern Minnesota (fig. 6), contains Foraminifera which were studied

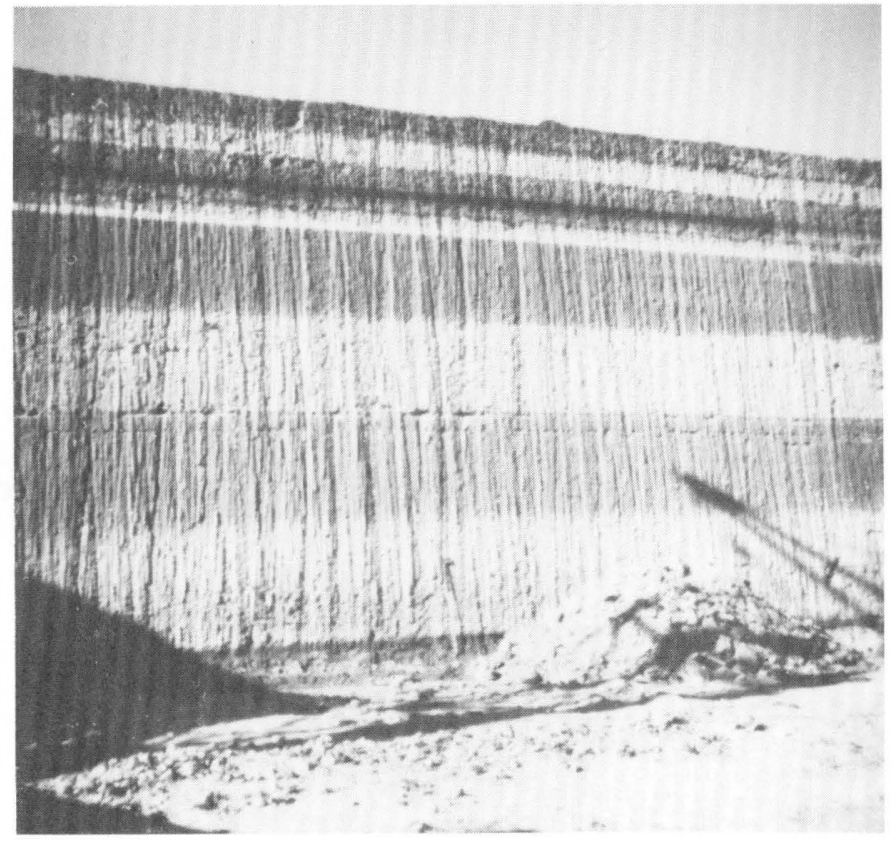

Figure 10-Upper Cretaceous strata in the Ochs Brick and Tile Company's claypit about $3 \mathrm{~km}$ southwest of Springfield, Minn. (table 2, outcrop G). This marine and nonmarine sequence is about $8.6 \mathrm{~m}$ thick and includes a bed of lignite (arrow), about $30 \mathrm{~cm}$ thick, near the top.

by Bergquist (written commun., 1969). He suggested that the noncalcareous shale and sandstone at depths of 246-264 m (807-866 ft) are approximately equivalent to the Graneros Shale and are of Cenomanian Age. Schoon (1965) and Austin (1972) indicated that the mainly nonmarine Dakota Formation of eastern South Dakota and adjoining areas was deposited during a marine transgression, and, therefore, the formation was progressively younger from west to east. The Dakota and the overlying lower part of the Graneros Shale at Sioux City, Iowa, include beds of late Cenomanian age (fig. 7, zone 7) and could presumably include younger beds of late Cenomanian age northeast of Sioux City, near Springfield and New Ulm, Minn. The nonmarine and shallow-marine strata of Cenomanian Age, which overlie the residuum at Springfield and New Ulm, are lithologically similar to the Dakota and the lower part of the Graneros at Sioux City; but the fossils indicate that some of the strata near Springfield are of mid-Graneros age (late Cenomanian; fig. 7, zone 8). On the basis of these data and interpretations, the strata at Springfield and New Ulm and the Ostrander Member of the Windrow Formation in southeastern Minnesota are, at least partly, of late Cenomanian age as Austin (1972) proposed, and the marine beds, which overlie the Windrow, may be laterally equivalent to the Greenhorn Formation. 


\section{ROCKS OF TURONIAN AGE}

Strata of Turonian Age crop out and have been penetrated by boreholes in the eastern parts of Nebraska, South Dakota, and North Dakota, and in the western parts of Minnesota and Iowa. In much of this region, these beds are assigned to the Greenhorn Formation and to the overlying Carlile Shale. At outcrops, the limestone in the Greenhorn forms ledges and the shale in the Carlile generally forms slopes.

The Greenhorn Formation conformably overlies either the Graneros Shale or the Belle Fourche Shale. Along the Missouri and Big Sioux Rivers, the Greenhorn is about 9 $\mathrm{m}$ thick and consists mainly of interbedded fossiliferous limestone and calcareous shale (Burchard, 1904, p. 151; Todd, 1908, p. 2; Simpson, 1960, p. 18-19), which were deposited largely in open-marine environments. The fossils are mostly fragments of the bivalve Mytiloides mytiloides (Mantell) of early and middle Turonian age, but they include the cephalopod Collignoniceras woollgari of middle Turonian age (fig. 7, probably zone 12), at the top of the formation.

In borehole 1 near Hawarden, Iowa (fig. 6), the Greenhorn is $8 \mathrm{~m}$ thick and consists of interlaminated limestone and calcareous shale. The formation was also penetrated by borehole 2 near Tyler, Minn. (fig. 6), where the sequence is about $13 \mathrm{~m}$ thick and is composed largely of calcareous shale (C. R. Collier and H. R. Bergquist, written commun., 1969). In boreholes near De Smet, S. Dak., the Greenhorn is $7-10 \mathrm{~m}$ thick (Bolin and Petsch, 1954).

In northeastern South Dakota and the adjacent part of
Minnesota, the Greenhorn crops out and was also encountered in stone quarries and boreholes. In boreholes near Aberdeen, S. Dak., the formation is as much as 21 $\mathrm{m}$ thick (Koch and Bradford, 1976, table 4). The formation is about $9-11 \mathrm{~m}$ thick where penetrated by water wells near Sisseton, S. Dak. (Merewether and Gray, 1978, p. 9; this report, fig. 6). Shurr (1979) described the upper part of the Greenhorn at an outcrop (table 2, outcrop E) near the town of Browns Valley, Minn., where the formation consists mainly of thin beds of limestone and chalk and is about $3 \mathrm{~m}$ thick (fig. 11). Fossils in these beds include the pelecypod Mytiloides mytiloides (Mantell) (fig. 7, zones 11 and 12) and the ammonite Watinoceras coloradoense (Henderson) (fig. 7, zone 10) of early Turonian age. In quarries near Odessa, Minn. (fig. 6; table 2, outcrop F), the Greenhorn contains Mytiloides mytiloides (Mantell), oysters, and fish bones; and it overlies rocks of Precambrian age. Where penetrated by boreholes 11 and 12 (table 1) in southeastern North Dakota, the formation is 9-12 m thick and is composed of fossiliferous, silty shale (Moore, 1979 , p. 122,129$)$.

Hansen and Kume (1970, fig. 4) reported that the Greenhorn in the vicinity of Grand Forks is as much as $29 \mathrm{~m}$ thick and consists of interstratified marlstone, calcareous shale, limestone, and bentonite. The Greenhorn is represented in Manitoba and Saskatchewan, Canada, by the Keld Member of the Favel Formation (fig. 7), which is composed mainly of calcareous shale and contains Mytiloides mytiloides (Mantell) (McNeil and Caldwell, 1981).

Lindholm, Oakes, Ericson, and Helgesen (1972) noted

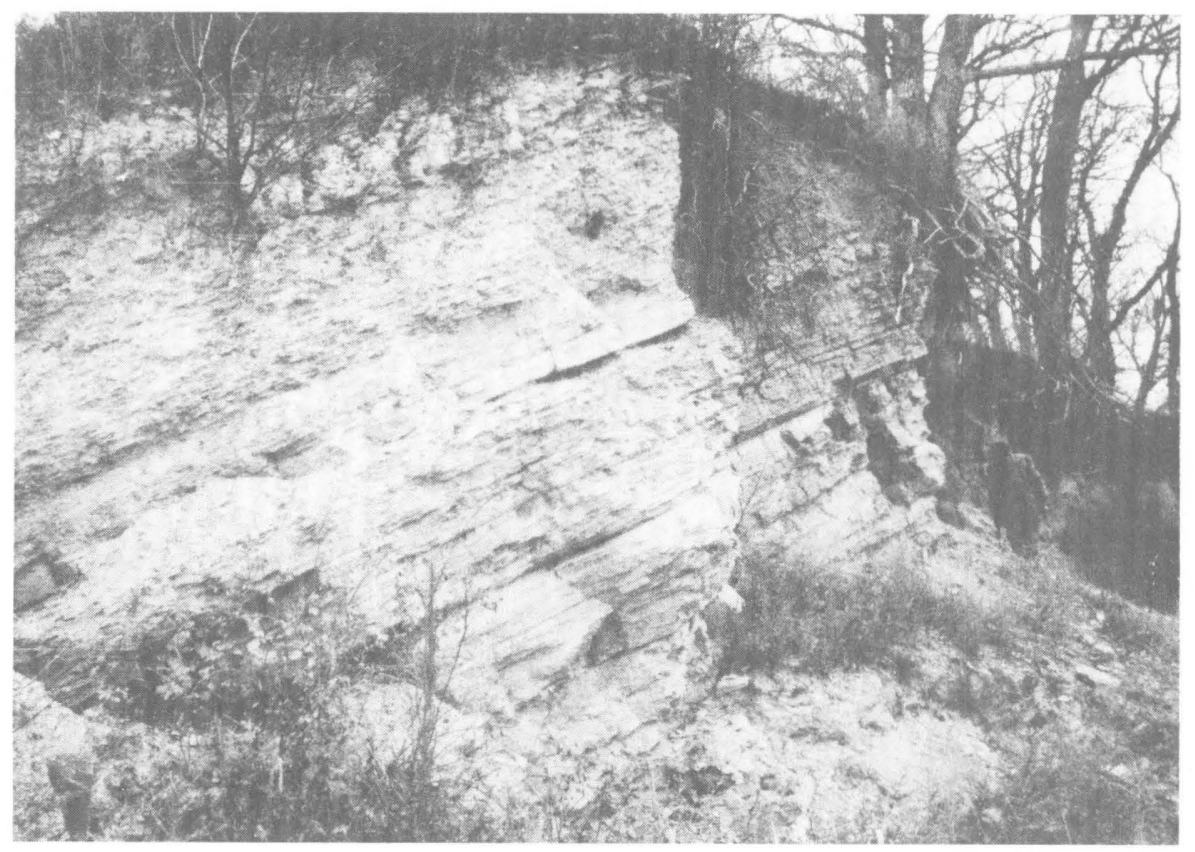

Figure 11.-Upper part of Greenhorn Formation (about $3 \mathrm{~m}$ thick) at outcrop $8 \mathrm{~km}$ northeast of Browns Valley. Minn. (table 2, outcrop E). 
that borehole 7 in central Minnesota (fig. 7; table 1) was producing water reportedly from a Cretaceous limestone, which may be part of the Greenhorn Formation. Samples of shale from borehole 13 (table 1) near Richmond, Minn., were supplied by G. W. Shurr and examined for Foraminifera by B. R. North and W. G. E. Caldwell. The sparse fauna in samples of calcareous and noncalcareous shale is characteristic of the Greenhorn and the lower part of the Carlile. If the upper part of the Windrow Formation in southeastern Minnesota consists of nonmarine strata of Graneros age (late Cenomanian), the overlying marine rocks (Austin, 1972, p. 61) may represent the Greenhorn.

The Carlile Shale conformably overlies the Greenhorn Formation and is composed of noncalcareous shale and minor calcareous shale of offshore-marine origin, and minor sandstone of nearshore-marine origin. In the Minnesota region, the Carlile is generally $40-120 \mathrm{~m}$ thick (fig. 12); in much of the region it is unconformably overlain by the Niobrara Formation. At outcrops in the vicinity of Vermillion, S. Dak., the Carlile is $50-65 \mathrm{~m}$ thick and contains fossiliferous calcareous concretions and sparse sandstone in the upper part of the formation (Todd, 1908, p. 2; Condra, 1908, p. 12). The fossils include Subprionocyclus percarinatus (Hall and Meek) of middle Turonian age (fig. 7, zone 14). A core of the lower part of the Carlile from borehole 1 near Hawarden, Iowa (fig. 6), contains Collignoniceras woollgari regulare of middle Turonian age (fig. 7 , zone 13).

In water wells in eastern South Dakota and at outcrops along the James River near Mitchell (fig. 6), the upper part of the Carlile commonly includes a body of sandstone which has been assigned to the Codell Sandstone Member of the Carlile Shale (Barkley, 1952). The sandstone member is at the top of the Carlile or as much as $15 \mathrm{~m}$ below the top of the formation, and it is generally 6-15 m thick (Todd, 1903, p. 2). Near Mitchell, the average thickness of the Codell is about $14 \mathrm{~m}$ (Steece and Howells, 1965, p. 40). Darton (1909, p. 49) reported that the sandstone is brown, massive, coarse grained, and locally pebble bearing and crossbedded. Todd (1903, p. 2) reported that the Codell near Mitchell contains shark teeth and, at a few outcrops, traces of fossil wood and leaves. At some outcrops between Mitchell and Olivet, S. Dak., the lower part of the member is composed of interstratified calcite-cemented and friable sandstone and lesser amounts of clay. The sandstone in the Codell is fine grained to coarse grained and locally contains pebbles, as much as $5 \mathrm{~cm}$ in diameter, of shale, sandstone, limestone, chert, and phosphatic material. Sequences of sandstone beds commonly are coarser grained at the top than at the base. Units of sandstone are as much as $8 \mathrm{~m}$ thick and are irregularly bedded and cross stratified. (Some tabular sets are about $30 \mathrm{~cm}$ thick; see fig. 13.) Outcrops southeast of Mitchell (SW $1 / 4$ sec. 17, T. 102 N., R. $59 \mathrm{~W}$.; fig. 6) display herringbone crossbeds and other planar crossbeds, which indicate many paleocurrent directions, and overturned foreset laminae, which indicate strong sediment-laden currents. Between Mitchell and Olivet, the member contains bone fragments, fish teeth, bored wood, and Thalassinoides. The Codell Sandstone Member in southeastern South Dakota was deposited in shallow-marine environments near the eastern shore of a Turonian sea. At the outcrops near Mitchell (fig. 6), the Codell may have been deposited in a delta-front environment. The member and the underlying marine shale probably represent a marine regression in eastern South Dakota during middle Turonian time. Rice (1977) has shown that the Codell can be traced westward to a featheredge in central South Dakota and that it does not grade westward into the Turner Sandy Member of the Carlile Shale of western South Dakota.

In boreholes near De Smet, S. Dak., the Carlile Shale generally is $40-60 \mathrm{~m}$ thick (Bolin and Petsch, 1954). Cores and drill cuttings from the Carlile in borehole 2 near Tyler, Minn. (fig. 6), consist mainly of fossiliferous, noncalcareous shale. In northeastern South Dakota, the formation is as much as $84 \mathrm{~m}$ thick near Aberdeen (Koch and Bradford, 1976, table 4) and about $70 \mathrm{~m}$ thick at borehole 3 (Merewether and Gray, 1978, p. 9-10). At outcrops in the area, the Carlile is composed of shale and minor siltstone and sandstone. At outcrop B (table 2) in the Dakota Granite Company's quarry, a lower part of the formation is about $5 \mathrm{~m}$ thick and consists of fossiliferous, calcareous shale. These beds, which rest on Precambrian rocks (fig. 8), are slightly sandy at the base of the sequence and enclose scattered, rounded pebbles of chert as much as $2 \mathrm{~cm}$ long, rounded pieces of fossil wood, as much as $15 \mathrm{~cm}$ long, abundant fossil fish bones, and molluscan fossils. The mollusks include $\mathrm{Col}$ lignoniceras woollgari regulare of middle Turonian age (fig. 7, zone 13). A lower part of the Carlile and the underlying Greenhorn Formation crop out near Browns Valley, Minn. (table 2, outcrop E). The Carlile at this outcrop is about $36 \mathrm{~m}$ thick and is mainly noncalcareous shale, but it includes calcareous shale at the base of the sequence and a unit of sandstone and siltstone, about 6 $\mathrm{m}$ thick, near the top of the sequence (Shurr, 1979, p. 8). An ammonite collected from about $1.5 \mathrm{~m}$ below the sandstone unit has been tentatively identified as Subprionocyclus percarinatus (fig. 7, zone 14) of middle Turonian age.

In southeastern North Dakota at borehole 11 (fig. 6; table 1), the Carlile Shale is at least $58 \mathrm{~m}$ thick (Moore, 1979, p. 122). Hansen and Kume (1970, fig. 4) reported that the Carlile in the area of Grand Forks, N. Dak., is as much as $79 \mathrm{~m}$ thick. In northeastern North Dakota, the formation reportedly is about $73 \mathrm{~m}$ thick (Bluemle, 1973, fig. 3) but probably ranges from about 70 to $120 \mathrm{~m}$ in thickness (fig. 12). The upper part of the Carlile crops out along the Pembina River in northeastern North Dakota where it is conformably overlain by the Niobrara Formation (table 2, outcrop D). Arndt (1975, p. 5-6) 


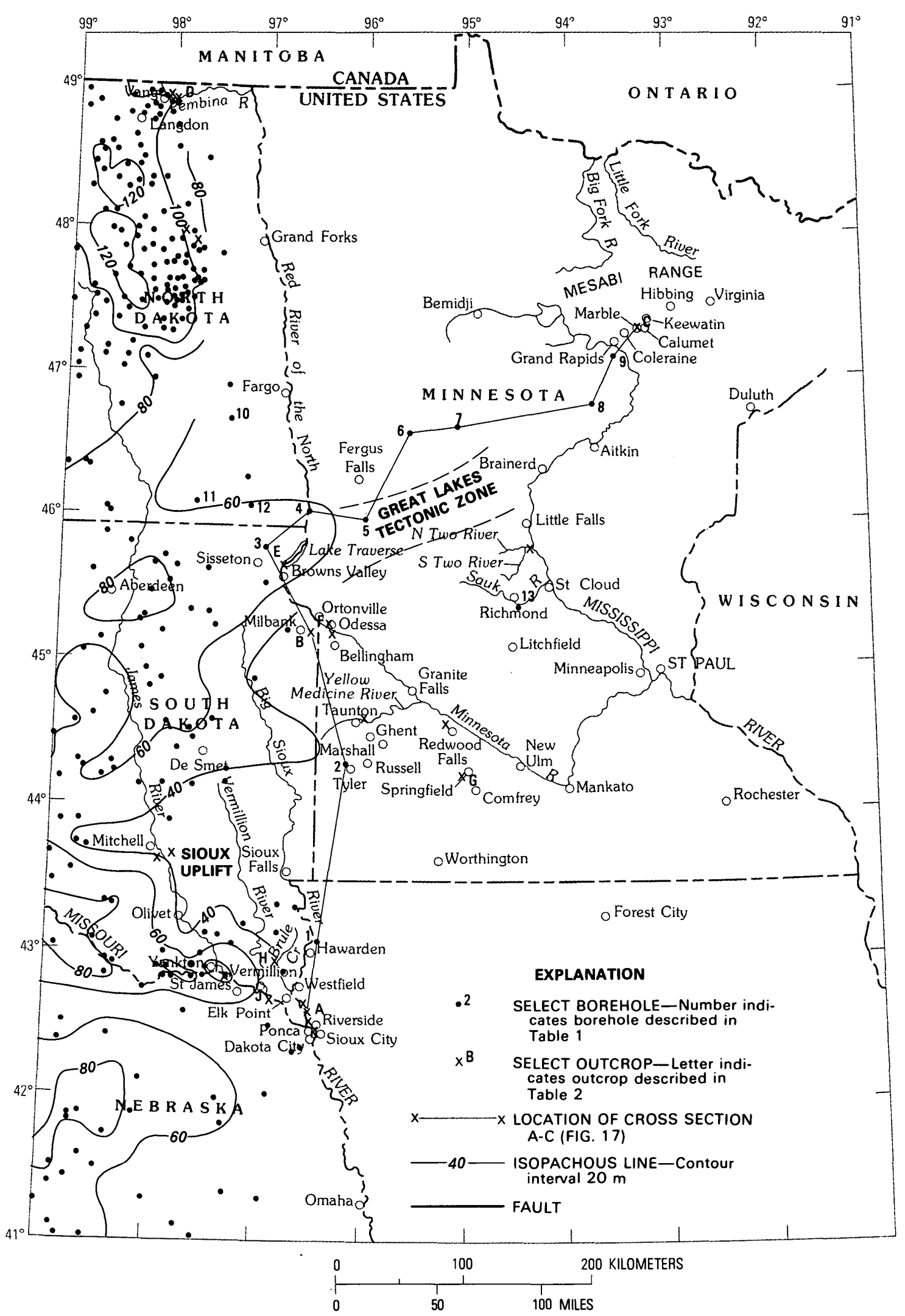

F IGURE 12.-Approximate thickness of the Carlile Shale where overlain by the Niobrara Formation in the Minnesota region. 


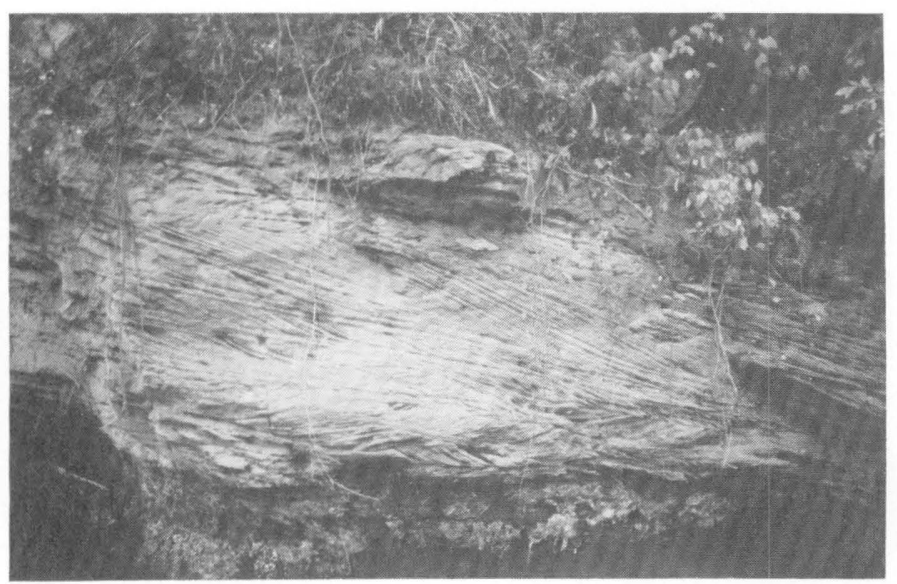

F IGURE 13.-Outcrop of Codell Sandstone Member of Carlile Shale, 11 $\mathrm{km}$ southeast of Mitchell, S. Dak. (SW $1 / 4$ sec. 17, T. 102 N., R. 59 W., Hanson County). Crossbedded sequence is about $1 \mathrm{~m}$ thick.

stated that the upper part of the Carlile in this area consists of at least $30 \mathrm{~m}$ of mostly noncalcareous black shale. Fossil mollusks collected from about $40 \mathrm{~m}$ below the top of the formation by Wosick (1977) include Scaphites that resemble species of probable latest Turonian or earliest Coniacian age (fig. 7, zones 20 or 21).

The Carlile Shale of North Dakota is included in the upper part of the Favel Formation and the Morden Shale of Manitoba, Canada (fig. 7). Apparently, the Morden Shale of McNeil and Caldwell (1981) includes beds of
Turonian Age that are represented by an unconformity at the top of the Carlile in eastern South Dakota and adjacent areas.

Some of the Carlile Shale was penetrated by borehole 2 (fig. 6) in southwestern Minnesota and by boreholes and wells in central Minnesota near the town of Richmond. In 1872, Kloos described the clay, shale, and minor lignite encountered in a water well south of Richmond. That sequence of beds, which is about $22 \mathrm{~m}$ thick, contains marine fossils of middle Turonian age (fig. 7, zones 12,13 , or 14) and probably is a lower part of the Carlile. Samples of shale provided by G. W. Shurr, from borehole 13 (table 1) in the same area, contain Foraminifera that are typical of the lower part of the Carlile (B. R. North and W. G. E. Caldwell, written commun., 1979).

At outcrops along the Missouri River between Vermillion and Yankton, S. Dak., shale in the upper part of the Carlile is sharply overlain by calcareous strata of the Niobrara Formation (fig. 14). The Codell Sandstone Member of the Carlile is absent in much of that area. Georgesen (1931, p. 31) and Simpson (1960, p. 20) indicated that the Carlile-Niobrara contact at those outcrops is a disconformity with as much as $60 \mathrm{~cm}$ of local relief. Furthermore, molluscan fosssils from the upper part of the Carlile (fig. 7, zone 14) and the basal Niobrara (fig. 7, zone 24) indicate a significant hiatus at the contact (Hattin, 1975, p. 200-201). In contrast, the upper part of the Carlile and the basal Niobrara are gradational and seem to be conformable at outcrops along the Pembina River in northeastern North Dakota.

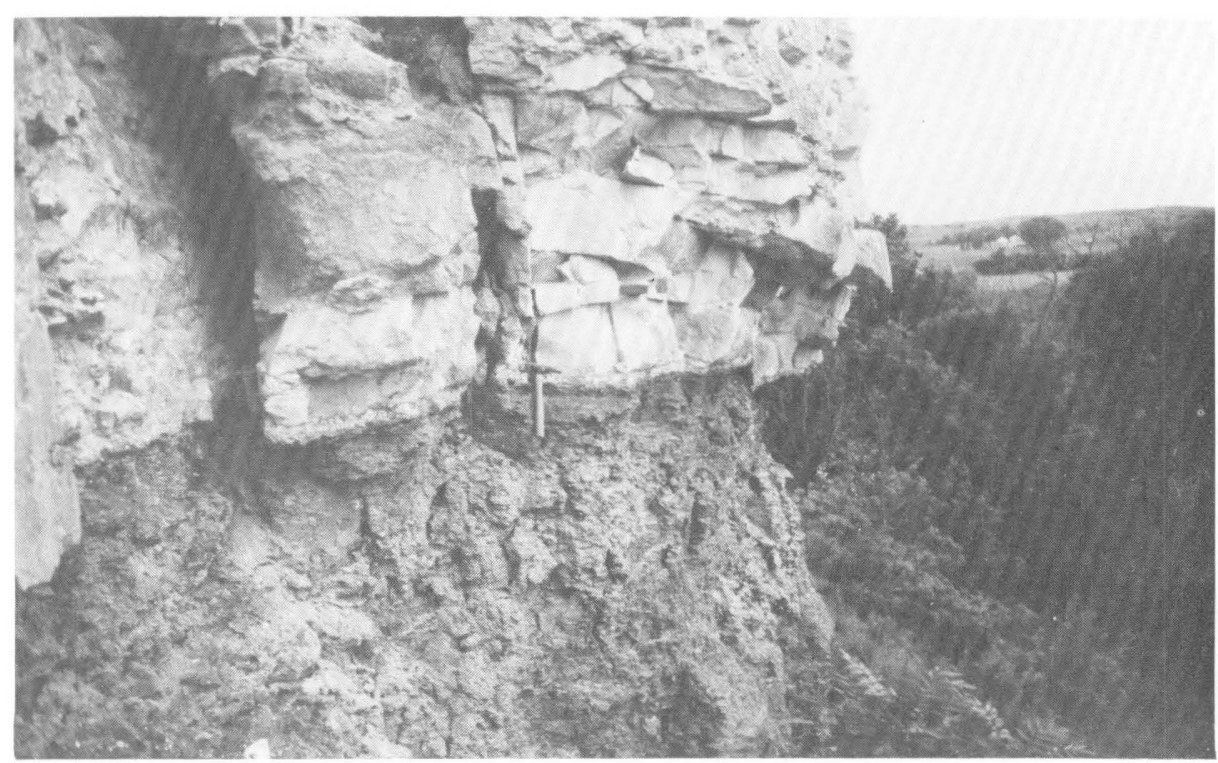

F IGURE 14.-Disconformable contact of Carlile Shale and overlying Niobrara Formation in northeastern Nebraska, about $19 \mathrm{~km}$ west of Vermillion, S. Dak. (NW $1 / 4$ sec. 12, T. 32 N., R. 2 E., Cedar County). Hammer at contact is $28 \mathrm{~cm}$ long. 
Moreover, fossils from the Carlile in that area probably represent zone 20 or 21 (fig. 7) and those from the basal Niobrara, zone 24 (fig. 7). The hiatus of the Yankton area is either absent or relatively small near the Pembina River.

\section{ROCKS OF CONIACIAN AND SANTONIAN AGES}

In the Minnesota region, strata of late Coniacian and Santonian age are within the Niobrara Formation. At outcrops along the Missouri River between Elk Point and Yankton, S. Dak. (fig. 6), the Niobrara consists mainly of argillaceous limestone and is as much as $62 \mathrm{~m}$ thick (Simpson, 1960, p. 21). A sharp contact divides the Niobrara from the underlying Carlile Shale (fig. 14). Near Yankton (table 2, outcrop I), the basal Niobrara contains the inoceramid Volviceramus involutus (J. Sowerby) of late Coniacian age and the trace fossil Thalassinoides, which lies parallel to the bedding planes. The upper part of the formation in that area contains Platyceramus platinus (Logan) of Santonian Age.

Where penetrated by boreholes near De Smet, S. Dak., the Niobrara is commonly $42-47 \mathrm{~m}$ thick (Bolin and Petsch, 1954). Koch and Bradford (1976, table 4) reported that the formation is as much as $52 \mathrm{~m}$ thick in the vicinity of Aberdeen, S. Dak. In borehole 3 (fig. 6) in northeastern South Dakota, the Niobrara is probably about $15 \mathrm{~m}$ thick (Merewether and Gray, 1978, p. 10).

The formation crops out in eastern North Dakota, west of Grand Forks (fig. 6), where it consists largely of marlstone and shale and is as much as $35 \mathrm{~m}$ thick (Hansen and Kume, 1970, p. 15, fig. 4). In northeastern North Dakota, the Niobrara conformably overlies the Carlile Shale at outcrops along the Pembina River (table 2 , outcrop D). Arndt $(1975$, p. 6) reported that the Niobrara in that area is mainly calcareous shale and is at least $46 \mathrm{~m}$ thick. The Niobrara near the Pembina River includes a unit of noncalcareous shale, which contains Platyceramus platinus of Santonian age, and an underlying basal unit of calcareous shale, which contains Volviceramus involutus (J. Sowerby) of late Coniacian age. In southernmost Manitoba, Canada, the Niobrara is about $50 \mathrm{~m}$ thick and consists mostly of calcareous shale (McNeil and Caldwell, 1981).

Outcrops of shale and clay along the Little Fork and Big Fork Rivers in northeastern Minnesota, were ascribed to the Cretaceous by Winchell (1893, p. 220). Microfossils from strata near the Little Fork were described by Woodward and Thomas (1895) and were tentatively assigned to Coniacian-Santonian time by Bolin (1956, p. 279). After studying illustrations of these microfossils, W. G. E. Caldwell and Ruth North (written commun., 1978) suggested that the species were typical of the microfauna in the Niobrara Formation. Thiel (1947, p. 151) has reported fossiliferous, bluish-gray clay, in a layer about $12 \mathrm{~m}$ thick, at a locality near the Little Fork River. However, Thiel (1947) and Bolin (1956) also indicated that the beds, where unfossiliferous, are not easily distinguished from Quaternary sediments. Consequently, the shale and clay in northeastern Minnesota may be of Quaternary age, and the Cretaceous fossils may have been transported southward from outcrops in Canada and redeposited in this area by Pleistocene glacial activity.

Woodward and Thomas (1885) also reported Cretaceous Foraminifera in Pleistocene clay near Litchfield in central Minnesota. Their drawings of many species have been studied by W. G. E. Caldwell and Ruth North (written commun., 1978), who have tentatively proposed that the fauna was derived from the Niobrara Formation.

Outcrops of sedimentary rocks near Marshall and Redwood Falls, in southwestern Minnesota (fig. 6), contain Foraminifera, which Bolin (1956, p. 284-285) indicated were typical of the Niobrara in Nebraska and South Dakota. He also suggested that the rocks may be reworked deposits of glacial origin. Bolin's sample locality northwest of Marshall is in the same area as outcrops of clay (Winchell, 1874, p. 189) and marine sandstone. Winchell $(1874$, p. 189) stated that the clay is blue, but yellowish-blue where weathered, and "at least ten or fifteen feet" ( 3 or $5 \mathrm{~m}$ ) thick. The sandstone is very fine grained, well sorted, and calcareous, and it includes some beds of ironstone. It also displays ripplecrossbedding, ripple marks, and abundant burrows; it weathers to slabs. Rodis (1963, fig. 5) located this outcrop and reported sandstone at altitudes of $320-354 \mathrm{~m}$ in a northwest-trending area that extends from Marshall to Taunton. He also reported limestone at altitudes of 378-384 $\mathrm{m}$ in a small area west of Marshall and northeast of Tyler. The limestone unit is generally about $2 \mathrm{~m}$ thick, fine grained, thickly bedded, and poorly indurated, and it locally overlies thin, discontinuous beds of sandstone (Rodis, 1963, p. N12-15). If the strata in these areas are horizontal, as Rodis (1963, p. N13) suggested, then they can probably be correlated with the rocks in borehole 2 near Tyler (fig. 6) by the use of altitudes. In borehole 2, the top of the Greenhorn Formation is at an altitude of about $300 \mathrm{~m}$, the top of the truncated Carlile sequence is at an altitude of about $344 \mathrm{~m}$, and the Niobrara Formation apparently has not been preserved. The limestone described by Rodis (1963, p. N15) resembles the Niobrara in eastern South Dakota, although it is thinner, and correlates with strata above the Carlile in borehole 2. The unit of limestone in the Marshall-Tyler area is probably part of the Niobrara and is similar to the basal part of the formation in eastern South Dakota. However, the rocks near Taunton, which contain microfossils typical of the Niobrara (Bolin, 1956, p. 283), are at altitudes of about $340-350 \mathrm{~m}$, which is significantly below the limestone unit. Furthermore, the lithology of the strata near the fossil locality seems more like that in the upper part of the Carlile, as Darton 
(1909, p. 52) suggested, than that of the Niobrara. These rocks could, however, be a sandy facies of the Niobrara that was deposited in nearshore-marine environments.

\section{SUMMARY OF STRATIGRAPHY}

In the vicinity of Sioux City, Iowa, the oldest formation treated in this report, the Dakota Formation, is composed dominantly of sandstone and was deposited in nonmarine and shallow-marine environments. Inasmuch as the formation in that area is conformably overlain by fossiliferous beds of late Cenomanian age (fig. 7, zone 7), it can be inferred that at least the upper part of the Dakota is of Cenomanian Age. The sandstone in this part of the formation in northwestern Iowa grades northward into shale of offshore-marine origin in eastern North Dakota. This laterally equivalent shale is in the lower part of the Belle Fourche Shale. The thickness of the Dakota ranges from about $140 \mathrm{~m}$ near Sioux City, where the formation is probably of Early and Late Cretaceous age, to about $124 \mathrm{~m}$ near Grand Forks, N. Dak. (Hansen and Kume, 1970, fig. 4), where the formation is of Early Cretaceous age. Sloan (1964, p. 5, fig. 11) interpreted the local thinning and the local absence of the Dakota in eastern South Dakota, southwestern Minnesota, and northwestern Iowa, where the Dakota and younger formations rest on Precambrian rocks, as evidence of an embayed coast of moderate relief.

The Graneros Shale of northwestern Iowa, northeastern Nebraska, and eastern South Dakota and the upper part of the Belle Fourche Shale of eastern North Dakota are composed largely of shale, which was deposited in offshore-marine environments during late Cenomanian time (fig. 7, zones 7-9). However, the basal part of the Graneros is locally of nearshore-marine origin where it overlies Precambrian rocks in eastern South Dakota and adjacent areas. The Graneros is as much as $50 \mathrm{~m}$ thick near Yankton, S. Dak., and the Belle Fourche, which includes some older beds, is about $76 \mathrm{~m}$ thick in northeastern North Dakota (Bluemle, 1973, fig. 3 ). Some of these strata are represented in northeastern Minnesota by the shale, sandstone, and conglomerate of nearshore-marine and nonmarine origin in the Coleraine Formation. Marine fossils in the Coleraine are of late Cenomanian age (fig. 7, zone 8). Part of the Graneros is probably represented in south-central Minnesota by some of the shale, sandstone, and lignite of shallowmarine and nonmarine origin near Springfield, and in southeastern Minnesota by some of the Windrow Formation. The fossil fauna and flora in these rocks are of Cenomanian Age and resemble the fossils in the Coleraine Formation.

The Greenhorn Formation in eastern North Dakota, eastern South Dakota, and adjacent areas consists mainly of calcareous shale and limestone (fig. 11) of offshore-marine and open-marine origin. However, the formation is of nearshore-marine origin where it onlaps
Precambrian rocks in westernmost Minnesota (table 2, outcrop F). Molluscan fossils of early and middle Turonian age (fig. 7, zones 10-12) are common in these beds. A fossiliferous, noncalcareous shale in borehole 13 (table 1) near Richmond, in central Minnesota, is probably a lateral equivalent of the Greenhorn. The thickness of the formation ranges from about $7 \mathrm{~m}$ near De Smet, S. Dak. (Bolin and Petsch, 1954), to about $29 \mathrm{~m}$ near Grand Forks, N. Dak. (Hansen and Kume, 1970, fig. 4).

In northwestern Iowa, northeastern Nebraska, and eastern South Dakota, the Carlile Shale is comprised largely of calcareous and noncalcareous shale; it also commonly includes the Codell Sandstone Member at the top of the formation. These strata were deposited during the middle Turonian (fig. 7, zones 12-14) in offshoremarine and nearshore-marine environments. In eastern North Dakota, the Carlile consists of shale of offshoremarine origin, without the Codell Sandstone Member, and includes strata as young as latest Turonian or earliest Coniacian (fig. 7, zone 20 or 21). The formation ranges in thickness from about $40 \mathrm{~m}$ in southeastern South Dakota to about $120 \mathrm{~m}$ in northeastern North Dakota. Shale of middle Turonian age, probably in the lower part of the Carlile, was also encountered in wells and boreholes near Richmond, Minn. The Codell Sandstone Member of eastern South Dakota, which thins to a featheredge in central South Dakota, probably was deposited in shallow-marine, delta-front, and nearshore bar environments. Regional differences in the age of the upper part of the Carlile (Hattin, 1975, text fig. 5) and in the thickness of the formation are evidence of an erosion surface at the top of the Carlile in eastern South Dakota and adjacent areas. The amount of truncation varies locally but seems to decrease generally toward the west.

The Niobrara Formation ranges in thickness from about $62 \mathrm{~m}$ near Yankton, S. Dak., to about $15 \mathrm{~m}$ in borehole 3 in northeastern South Dakota, and to about $50 \mathrm{~m}$ in southernmost Manitoba, Canada. Sparse collections of molluscan fossils indicate that the formation is at least of late Coniacian and early Santonian age. The Niobrara in southeastern South Dakota consists largely of clayey limestone, and it disconformably overlies the Carlile (fig. 14). Both the lithology and basal contact of the Niobrara change northward. In northeastern North Dakota and southern Manitoba, the formation is composed of calcareous and noncalcareous shale, and it conformably overlies and grades into the Carlile and Morden (fig. 7). Most of the Niobrara in the Minnesota region is of open-marine and offshore-marine origin. However, in eastern South Dakota and adjacent areas, where the formation rests on the truncated Carlile, the basal Niobrara probably was deposited in nearshoremarine environments during a marine transgression.

In conclusion, the Dakota, Graneros, and Greenhorn, which grade continuously upward from nonmarine sandstone to marine shale to marine limestone, apparently were deposited while the epicontinental sea was 
transgressing eastward. The strandline was oriented generally north-northeast. Shallow-marine and nonmarine strata of middle Cenomanian age, in the Dakota, crop out in the vicinity of Sioux City, Iowa. Shallowmarine and nonmarine strata of late Cenomanian age crop out in the Mesabi Range (Coleraine Formation) and near New Ulm, Minn. (unnamed sequence). The calcareous rocks of the Greenhorn in eastern South Dakota and adjoining areas were deposited in offshore-marine environments largely during the early Turonian. These rocks are probably represented by some of the shale encountered in boreholes near Richmond, in central Minnesota. Deposition of the Greenhorn was followed, without interruption, by deposition of the dominantly noncalcareous shale in the lower part of the Carlile, which reflects a marine regression in the Minnesota region in the middle Turonian. The Codell Sandstone Member of the Carlile, in eastern South Dakota, is of shallow-water, nearshore-marine origin and was deposited in the late middle Turonian during the same regression. Erosion of the top of the Carlile in eastern South Dakota may have begun in latest mid-Turonian time. The regression was followed by a marine transgression and deposition of shale in the upper part of the Carlile and the calcareous strata in the Niobrara during the late Turonian and Coniacian.

Marine invertebrate fossils of Turonian, Coniacian, and Santonian Ages (fig. 7, zones 13-26) have been found in glacial deposits at scattered localities in southern Minnesota, northern Iowa, and western and northeastern Illinois (Chap. A, this volume; Woodward and Thomas, 1895). Many of these fossils were collected in areas where Cretaceous strata of marine origin have not been recognized or where the age of the local Cretaceous beds seems significantly different than the age of the fossils. Obviously, the anachronous fossils were transported southward by glacial activity probably from outcrops as far north as northern Minnesota, U.S., and Manitoba and Ontario, Canada. The areal distribution and ages of these fossils can be interpreted as evidence that lower Upper Cretaceous strata of marine origin were present in a region in northern Minnesota, northern Wisconsin, northern Michigan, and Ontario prior to the Pleistocene. Furthermore, the diverse species from the glacial deposits represent a relatively continuous sequence of marine beds in the Carlile and Niobrara. In western Greenland, Birkelund (1965) described late Turonian, Coniacian, and Santonian molluscan species, which have also been collected from outcrops of the Carlile and Niobrara and from glacial drift in the Minnesota region. The similarity of the fauna at these widely separated localities is convincing evidence of a direct seaway between the two regions (fig. 15), as Williams and Stelck (1975, p. 10-12) postulated, at least during the late Turonian, Coniacian, and Santonian.

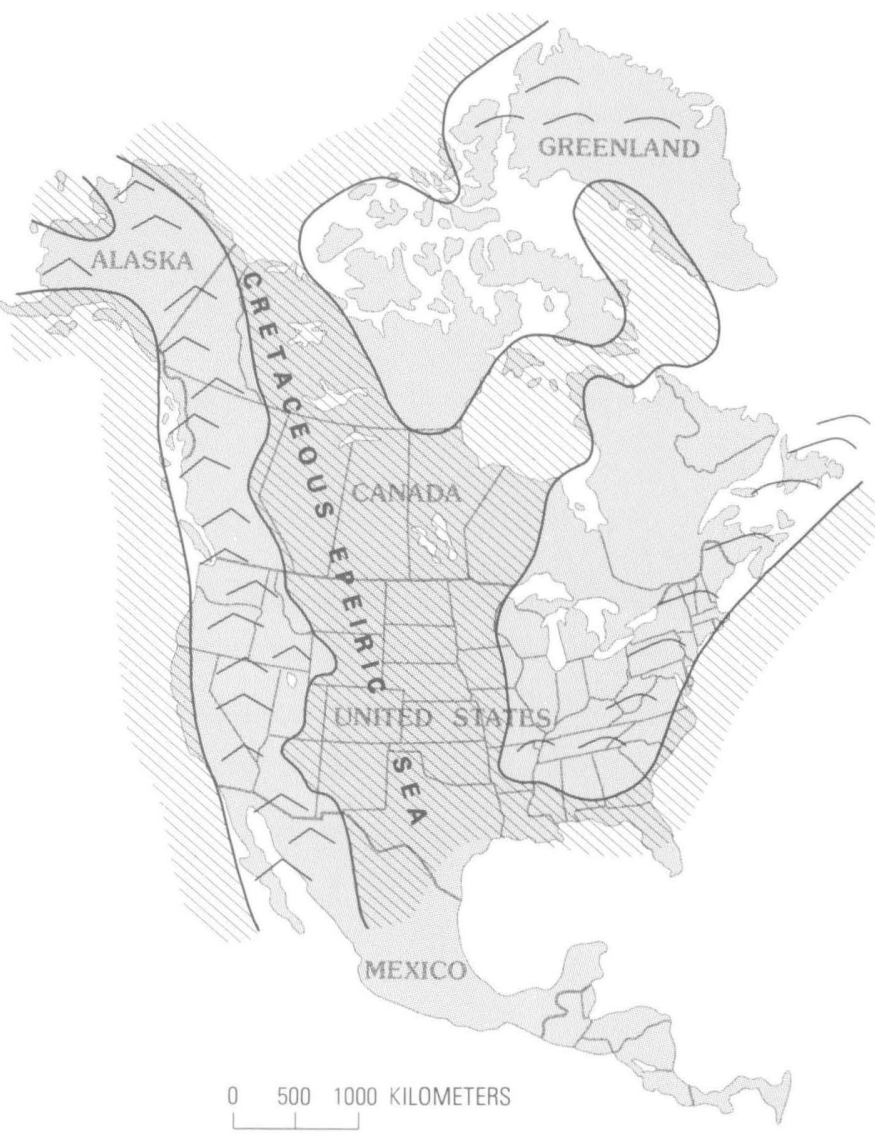

FiguRE 15.-Approximate distribution of land and sea in North America during Coniacian time (modified from Williams and Stelck, 1975, text fig. 5).

\section{STRUCTURE}

The structure of the lower Upper Cretaceous formations in the Minnesota region is best depicted by a structure-contour map of the top of the Greenhorn (fig. 16). Throughout the western part of the region, the Greenhorn seems to be the same age and is recognizable at outcrops and in boreholes. Altitudes for the structure map were obtained mainly from geophysical logs of boreholes and from reports by Bolin and Petsch (1954), Schoon (1968), Klausing (1966), Kelly (1968), Downey (1973), Hutchinson (1973), Armstrong and Luttrell (1978), and Armstrong (1979). In northeastern South Dakota and eastern North Dakota, the Greenhorn forms a syncline that has a northwest-trending axis and plunges northwest into the Williston Basin. The formation in northeastern Nebraska forms a syncline that has a southwest-trending axis and plunges southwest. These folds are separated by the Sioux uplift, a west-trending anticlinal feature. The structural relief on the top of the Greenhorn is at least $250 \mathrm{~m}$ between northeastern Minnesota and eastern North Dakota, and at least $200 \mathrm{~m}$ between northwestern Iowa and northeastern Nebraska (fig. 16). 


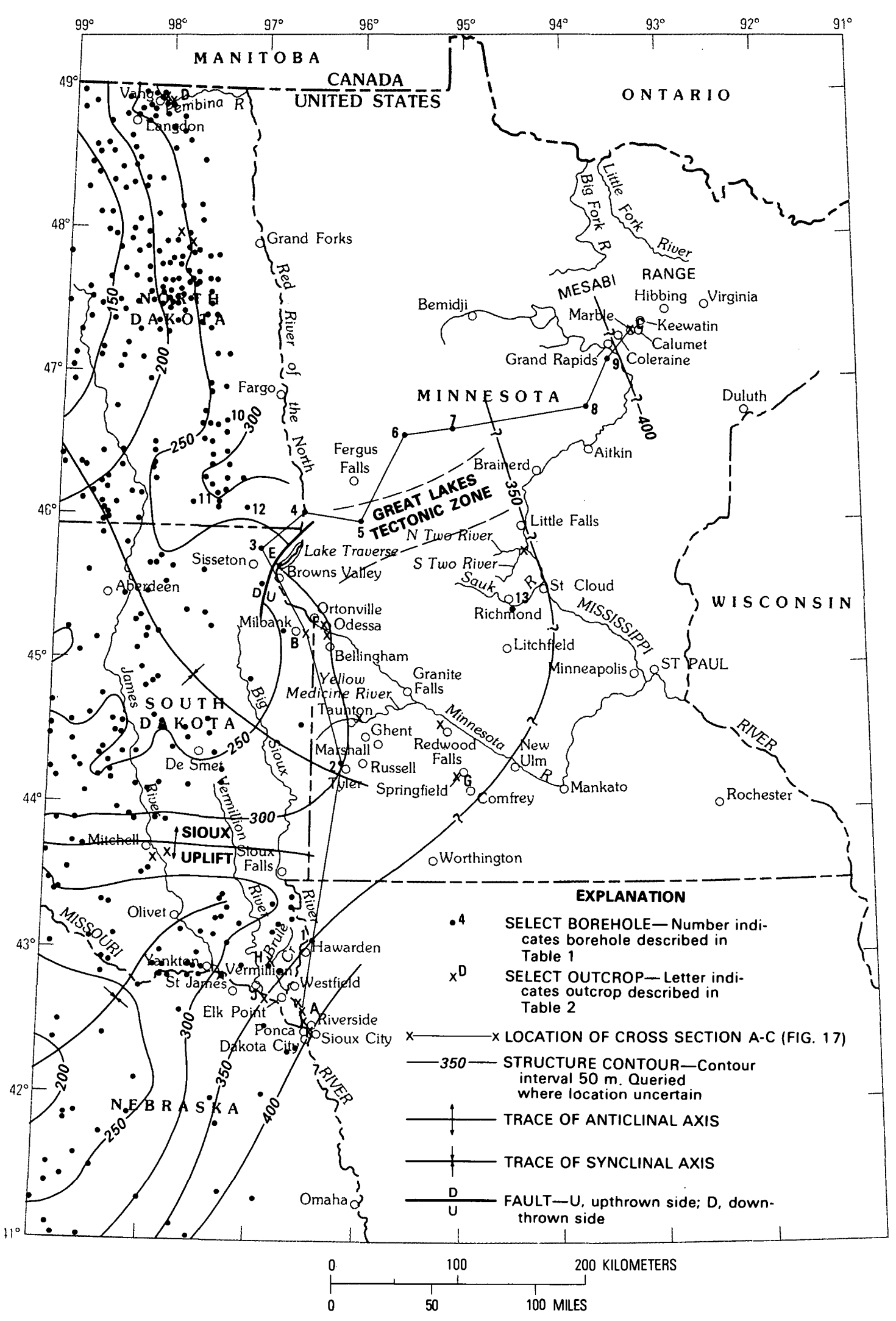

FIGURE 16.-Structures at the top of the Greenhorn Formation in the Minnesota region. 
Evidence of regional crustal deformation was also derived from mines and quarries (fig. 8) where fossiliferous beds of Cretaceous age rest on rocks of Precambrian age, from fossiliferous outcrops, and from cores where the depth and age of formations has been established. Cenomanian species of zone 8 (fig. 7) in the Coleraine Formation, which rests on Precambrian rocks in the Mesabi Range, occur at an altitude of about $390 \mathrm{~m}$ (fig. 17). Strata of about the same age in excavations near Springfield, in southwest Minnesota, are at an altitude of $314 \mathrm{~m}$. In northwestern Iowa at borehole 1 (fig. 17), fossils of zone 8 in the Graneros Shale were cored at an altitude of about $340 \mathrm{~m}$. At nearby outcrops along the Big Sioux River, these species were collected at an altitude of approximately $370 \mathrm{~m}$. Younger fossils, from the Greenhorn and Carlile Formations, were ob- tained from quarries and outcrops near Odessa and Browns Valley in western Minnesota. The Greenhorn (fig. 7, zones 10-12) in this area locally overlies Precambrian rocks and is at an altitude of about $300 \mathrm{~m}$. Exposures of fossiliferous Carlile (fig. 7, zone 13) are at an altitude of approximately $320 \mathrm{~m}$. The structural relief between strata of Graneros age in the Mesabi Range and younger strata in the Greenhorn near Odessa is at least $90 \mathrm{~m}$.

In northeastern South Dakota near Browns Valley, Minn., the structure-contour lines (fig. 16) are interpreted as indicating locally steep dips and a northnortheast-trending normal fault. Beds on the west side of this hypothetical fault are approximately $60 \mathrm{~m}$ lower than the same beds on the east side of the fault. Shurr (1979) reported that outcrops of the Greenhorn about 8

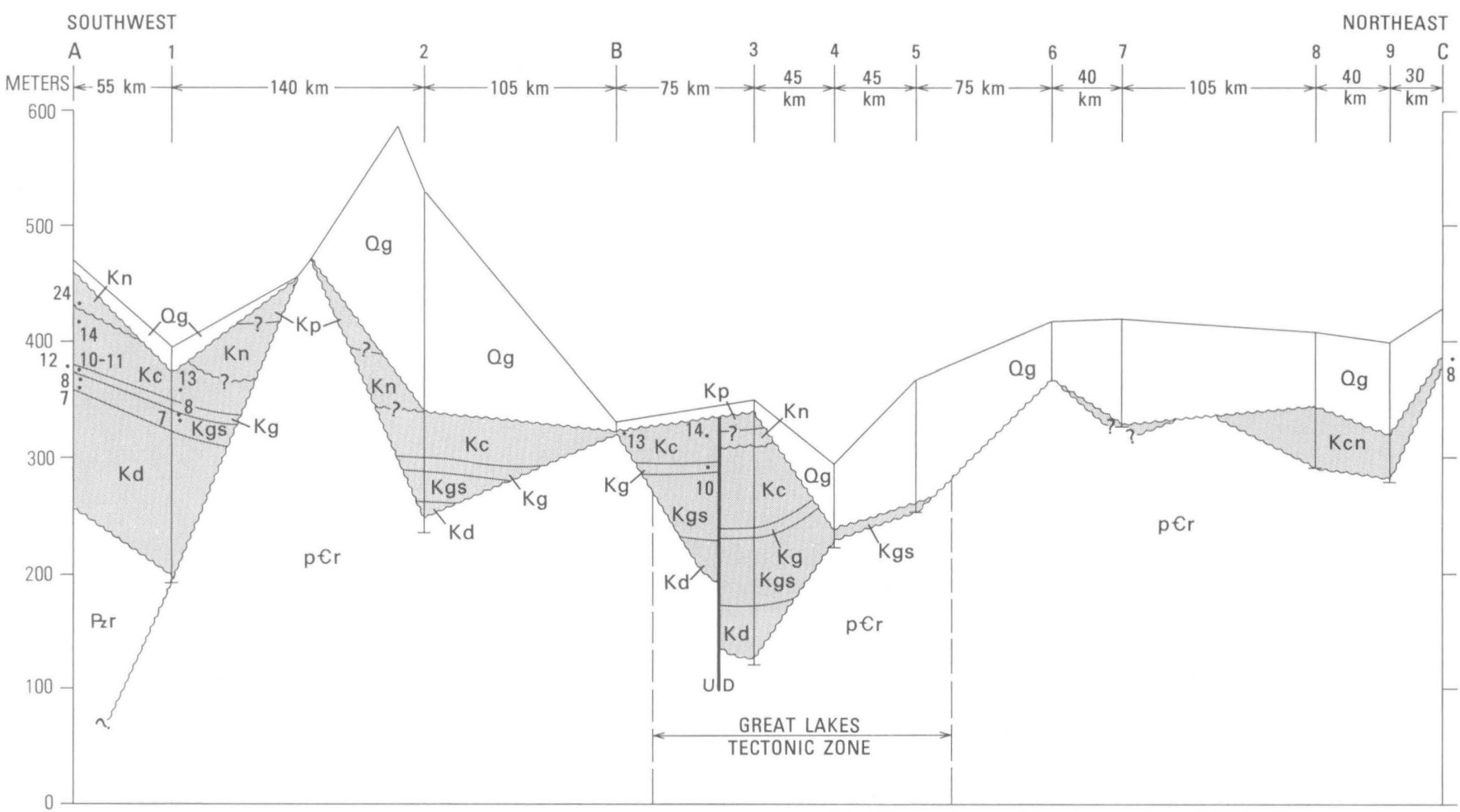

EX P L A N A T I O N
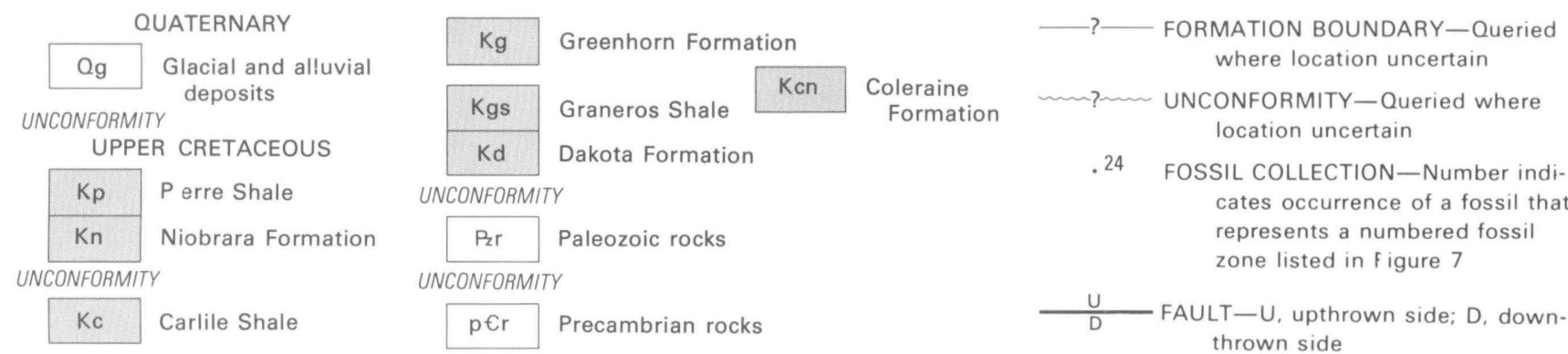

\begin{tabular}{c}
$U$ \\
\hline$D$ FAULT-U, upthrown side; D, down- \\
thrown side
\end{tabular}

FIgURE 17.-Cross section showing structure of Upper Cretaceous formations in northwestern Iowa, northeastern South Dakota, and Minnesota. Locations of outcrops A-C and boreholes 1-9 shown in figure 6 and listed in tables 1 and 2 . At locality A is a composite section of an outcrop. Fossil collections depicted near borehole 3 are from outcrops (altitude 300 m) near Browns Valley, Minn. 
$\mathrm{km}$ north of Browns Valley (table 2, outcrop E), on the east side of the fault, strike N. $70^{\circ} \mathrm{W}$. and dip $27^{\circ} \mathrm{NE}$. He also noted that these outcrops are within the Great Lakes tectonic zone (figs. 16, 17) of Sims, Card, Morey, and Peterman (1980), which trends southwest through this area. The zone separates dissimilar crustal bodies of Precambrian age and probably has been the loci of intermittent tectonism since Archean time. Sims, Card, Morey, and Peterman (1980) suggested that minor faulting had occurred along the zone during Late Cretaceous or Cenozoic time. However, the unusual attitude of the outcropping Greenhorn near Browns Valley could have been caused either by local tectonism or by the lateral pressure of an advancing Pleistocene ice sheet. If the dip and elevation of the outcrop have been increased by glacial activity, little supporting evidence would remain for the fault in northeastern South Dakota that is shown in figures 16 and 17 .

Deformation during early Late Cretaceous time is indicated by the stratigraphy of the Carlile and Niobrara Formations. In eastern South Dakota, the Carlile ranges in thickness from less than $40 \mathrm{~m}$ on the Sioux uplift to more than $80 \mathrm{~m}$ near Aberdeen and along the Missouri River, on the northwest and southwest flanks of the uplift, respectively (fig. 12). At outcrops in southeastern South Dakota, middle Turonian shale in the Carlile is disconformably overlain by upper Coniacian limestone of the Niobrara (figs. 7, 14). Georgesen $(1931$, p. 31) and Simpson (1960, p. 20) reported that the Carlile-Niobrara contact has as much as $60 \mathrm{~cm}$ of local relief. The top of the Carlile in this area evidently is an eroded surface (Hattin, 1975), which largely reflects tectonism during the late Turonian.

In eastern North Dakota, the Carlile thickens westward from less than $80 \mathrm{~m}$ to more than $120 \mathrm{~m}$ (fig. 12) but apparently was not truncated during the Cretaceous. At outcrops along the Pembina River, shale of latest Turonian and Coniacian age in the upper part of the Carlile grades into calcareous shale of late Coniacian age in the overlying Niobrara. Nearby, in southern Manitoba, the Morden Shale of middle Turonian through Middle Coniacian age is conformably overlain by the Niobrara Formation of late Coniacian and Santonian age (McNeil and Caldwell, 1981). Furthermore, mollusks found in the Pleistocene drift of southern Minnesota, northern Iowa, and western Illinois (Chapter A, this volume), form most of the fossil succession for midTuronian through mid-Coniacian time. Some of the specimens represent fossil zones that have not been recognized at outcrops in southern Minnesota and eastern South Dakota. Presumably, many of these fossils were transported southward by glacial action from an uninterrupted sequence of Cretaceous strata in northern Minnesota and adjoining areas. The presumed absence of truncation of the Carlile and the westward thickening and westward dip (fig. 16) of the formation in eastern
North Dakota probably indicate that the area was subsiding progressively westward during part of Turonian and Coniacian time.

From these data it can be concluded that Minnesota and northwest Iowa and eastern parts of North Dakota, South Dakota, and Nebraska were subjected to minor differential tectonism during the early Late Cretaceous. Structural deformation during the late Turonian probably caused truncation of part of the Carlile Shale in southeastern South Dakota and adjacent areas and, perhaps, the westward thickening of the Carlile in eastern North Dakota. Moreover, the local thickening of the Carlile in the southwest-trending area in northeastern South Dakota, along the strike of the Great Lakes tectonic zone (Sims and others, 1980) and in the northwest-trending area along the Missouri River, probably indicates that some of the Cretaceous deformation is related to fault zones in the underlying Precambrian rocks.

In a study of the Cretaceous strata in Colorado and adjoining States, Weimer (1978) concluded that regional variations in the thickness of the Carlile and Niobrara indicate tectonic movement of the Transcontinental arch (fig. 18) during mid-Cretaceous time. From northeastern Colorado, the Transcontinental arch trends northeast, crosses southeastern South Dakota at or near the Sioux uplift, and extends into Minnesota. The westward thickening of the Carlile in eastern North and South Dakota and the truncation of the Carlile on the Sioux uplift are evidence of structural deformation during the Turonian and may also reflect tectonism along the arch.

\section{MARINE REGRESSIONS AND TRANSGRESSIONS IN THE MINNESOTA REGION COMPARED WITH THOSE IN WYOMING}

The lower Upper Cretaceous formations in the Minnesota region were deposited near the eastern shore of an epicontinental sea; whereas, formations of the same age in Wyoming were deposited near the western shore of the sea (fig. 15) (Reeside, 1944, maps 3-7). At outcrops on the east side of the Powder River Basin near Osage, Wyo. (fig. 18), the strata are named, in ascending order, Belle Fourche Shale, Greenhorn Formation, Carlile Shale, and Niobrara Formation (fig. 19). The Carlile is composed of, from oldest to youngest, the Pool Creek Member, Turner Sandy Member, and Sage Breaks Member. Near Osage, the sequence of Belle Fourche, Greenhorn, Carlile, and basal Niobrara is about $370 \mathrm{~m}$ thick (Merewether, 1980). The Belle Fourche consists mainly of noncalcareous shale and was deposited in offshore-marine environments. These strata locally grade into the calcareous 


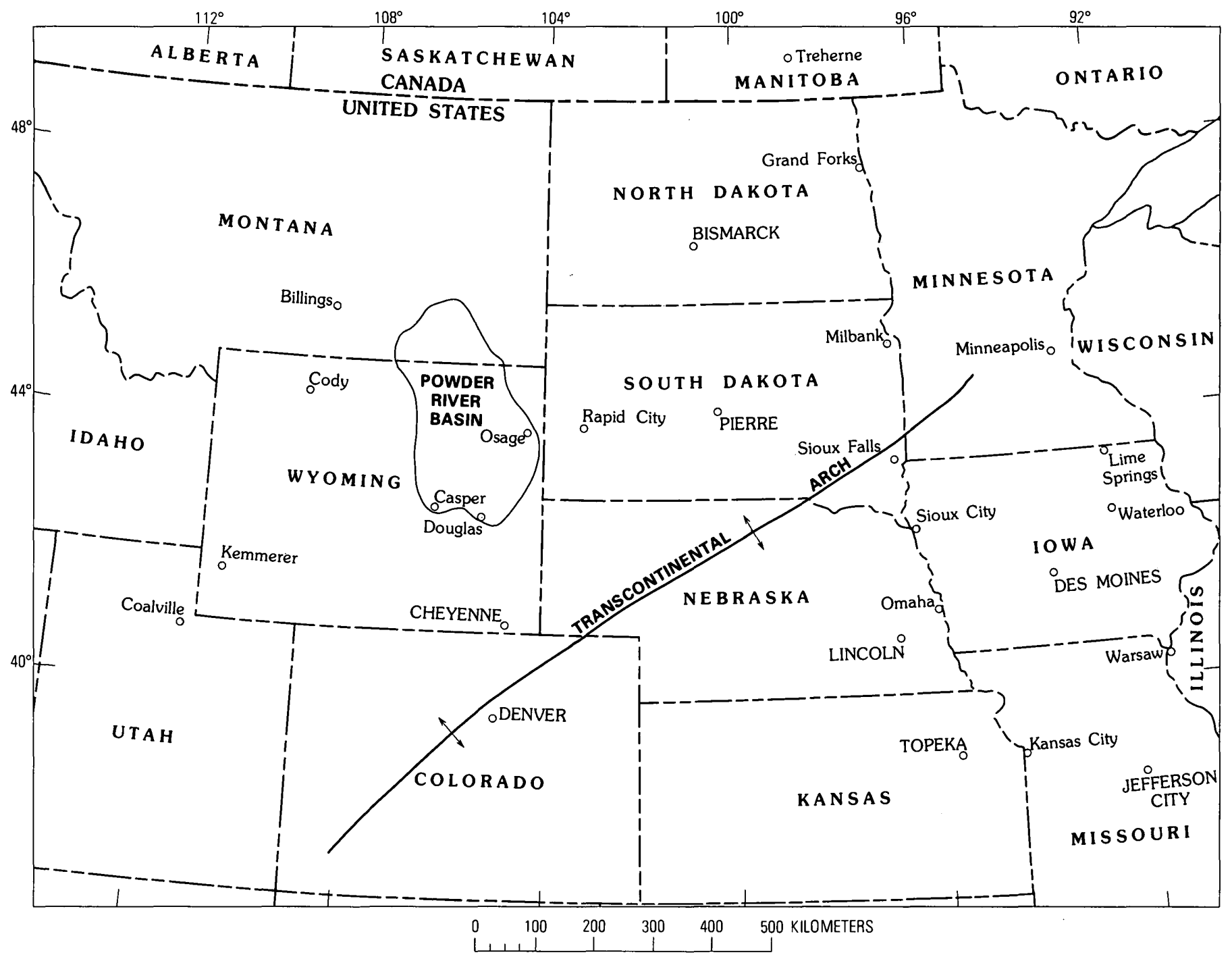

Figure 18.-The Minnesota region and States of the Central Rocky Mountains, showing locations of the Powder River Basin and the Transcontinental arch.

shale and limestone of the overlying Greenhorn, which was deposited in offshore-marine and open-marine environments. Limestone at the top of the Greenhorn is conformably overlain by the silty shale in the Pool Creek Member of the Carlile. The Pool Creek is of offshoremarine origin and is disconformably overlain by the basal sandstone bed of the Turner Sandy Member. Sandstone, siltstone, and shale of the Turner were deposited mainly in shallow-marine environments near the seaward terminus of a delta. These rocks are conformably overlain by the slightly calcareous shale of the Sage Breaks Member of the Carlile. Most of this member accumulated in offshore-marine environments. The Sage Breaks is disconformably overlain by the Niobrara For- mation, which includes a basal unit of calcareous and noncalcareous shale of open-marine and offshore-marine origin.

In the southwestern part of the Powder River Basin near Casper, Wyo. (fig. 18), lower Upper Cretaceous strata are assigned to the Frontier Formation and the lower part of the overlying Cody Shale (fig. 19). Locally, the Frontier is composed of, from oldest to youngest, the Belle Fourche Member, unnamed member, and Wall Creek Member; and the lower part of the Cody includes the Sage Breaks Member and the overlying Niobrara Member. This sequence is commonly about $360 \mathrm{~m}$ thick. The Frontier consists largely of interstratified shale, siltstone, and sandstone of shallow-marine origin. In the 


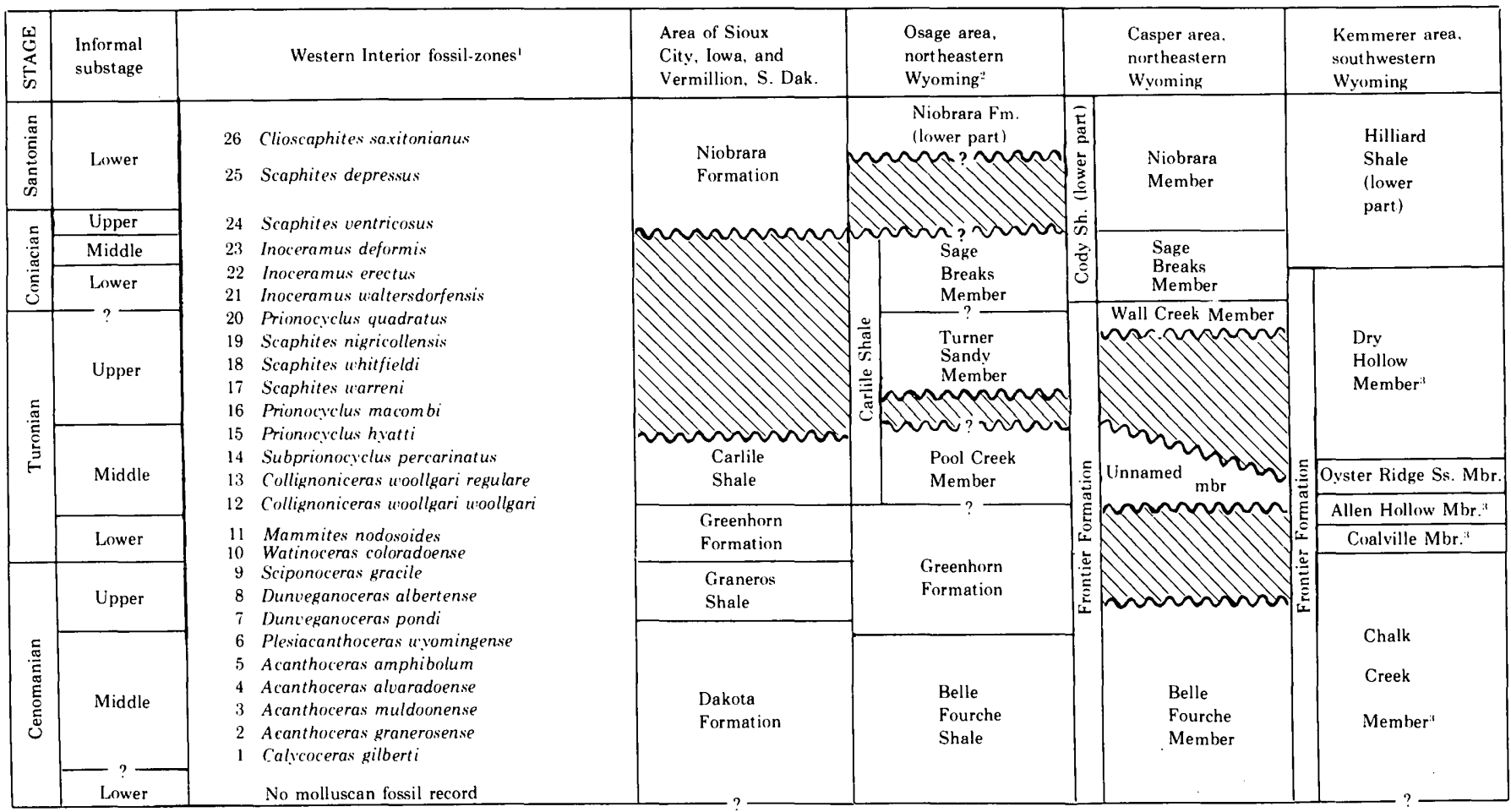

'Numbers representing some zones are shown in figure 17 and noted in text. "Age of basal contact of Niobrara Formation from Evetts (1976, p. 121). "Myers (1977).

FIGURE 19.-Correlation of the lower Upper Cretaceous formations at localities in the Minnesota region and in Wyoming. Hiatus in sequence patterned. Age of contacts with queries is estimated.

lower part of the Cody, the Sage Breaks and Niobrara are composed mainly of noncalcareous shale and calcareous shale, respectively, and were deposited in offshore-marine environments. Unconformities have been confirmed at the base and top of the unnamed member of the Frontier and, in the southern part of the basin near Douglas (fig. 18), at the base of the Niobrara (Merewether and others, 1979, p. 91-95).

Strata of mid-Cretaceous age in northwestern Wyoming are also included in the Frontier Formation and the lower part of the Cody Shale. In the vicinity of Cody, Wyo. (fig. 8), the Frontier is composed of three unnamed members, each of which is disconformable with the adjacent member (Merewether and others, 1975). At Cody, the outcropping Frontier is about $180 \mathrm{~m}$ thick and consists of interbedded shale, siltstone, and sandstone, and minor conglomerate, coal, and bentonite. These rocks were deposited in several nearshore-marine and deltaic environments. The lower part of the Cody Shale in this area consists of shale that accumulated mainly in offshore-marine environments.

In southwestern Wyoming near Kemmerer (fig. 18), the lower Upper Cretaceous strata are at least $660 \mathrm{~m}$ thick and are included in the Frontier Formation and in the lower part of the overlying Hilliard Shale (Cobban and Reeside, 1952). Myers (1977) divided the Frontier in that area into five members which are called, in ascending order, the Chalk Creek, Coalville, Allen Hollow, Oyster Ridge Sandstone, and Dry Hollow (fig. 19). The member names were previously applied to rocks at Coalville, in northeastern Utah (fig. 18), by Hale (1960, 1962) and Ryer (1977). In Wyoming, the Chalk Creek Member consists largely of shale, siltstone, and sandstone of nonmarine origin. The Coalville Member conformably overlies the Chalk Creek and is composed mainly of shallow-marine sandstone and shale. Conformably overlying the Coalville is the Allen Hollow Member, which consists of offshore-marine shale. The Oyster Ridge Sandstone Member conformably overlies the Allen Hollow and was deposited in shallow-marine environments. Sandstone of the Oyster Ridge is overlain by the Dry Hollow Member, which is composed of nonmarine rocks and a shallow-marine sandstone at the top. Hale (1962) suggested that the contact of the Oyster Ridge and the Dry Hollow is a disconformity and that the Dry Hollow is early Coniacian in age. Myers (1977) 
reported that the members are conformable and that the Dry Hollow is Turonian. The marine sandstone at the top of the Frontier is conformably overlain by offshoremarine shale of the Hilliard Shale.

The upper part of the Dakota Formation, the Graneros Shale, and the Greenhorn Formation near Sioux City, Iowa, are a sequence of Cenomanian and Turonian beds that grade from nonmarine sandstone at the base, through marine sandstone and offshore-marine shale, to open-marine limestone at the top. These strata were deposited continuously while the sea was transgressing eastward across a terrane of Paleozoic and Precambrian rocks (fig. 20). The sequence is the same age as the Belle Fourche Shale and overlying Greenhorn Formation of northeastern Wyoming, which also include noncalcareous shale and overlying calcareous beds. Most of these strata are represented on the west flank of the Powder River Basin by the Belle Fourche Member of the Frontier (fig. 19). In this basin, the areal distribution of the youngest discrete body of sandstone in the member is significantly less than the areas of the older bodies of sandstone. This uppermost sandstone was deposited in late Cenomanian (Greenhorn) time; consequently, the comparatively small lateral extent of the body may reflect a marine transgression (Merewether and others, 1979 , p. 95). In northwestern Wyoming at Cody, most of the beds of Greenhorn age are represented by an unconformity. Better evidence of a transgression can be ob- tained from outcrops of the Frontier in southwestern Wyoming, where nonmarine strata largely of Cenomanian Age in the Chalk Creek Member are overlain by marine strata mainly of early Turonian (late Greenhorn) age in the Coalville and Allen Hollow Members (Cobban and Reeside, 1952, fig. 2; Myers, 1977, fig. 2). The striking similarities in the ages of the transgressive-marine rocks on the east side of the Cretaceous seaway in North Dakota and Iowa and on the west side of the seaway in parts of Wyoming (fig. 20) can be interpreted as evidence of either continent-wide tectonic subsidence or the eustatic rise in sea level as suggested by Kauffman (1977, p. 89).

Nevertheless, the sequences of mid-Cretaceous strata at Casper in northeastern Wyoming (fig. 19) and at Cody in northwestern Wyoming seem to indicate a different series of events (fig. 20). Shallow-marine beds of Cenomanian Age in the Belle Fourche Member of the Frontier near Casper were truncated during an early Turonian marine regression and were subsequently buried by similar beds in the unnamed member during a middle Turonian transgression. At Cody, nearshoremarine and deltaic strata of Cenomanian Age in the lower unnamed member of the Frontier were truncated during a marine regression in early or possibly middle Turonian time and are overlain by shallow-marine beds in the middle unnamed member, which were deposited during a late middle Turonian transgression. However,

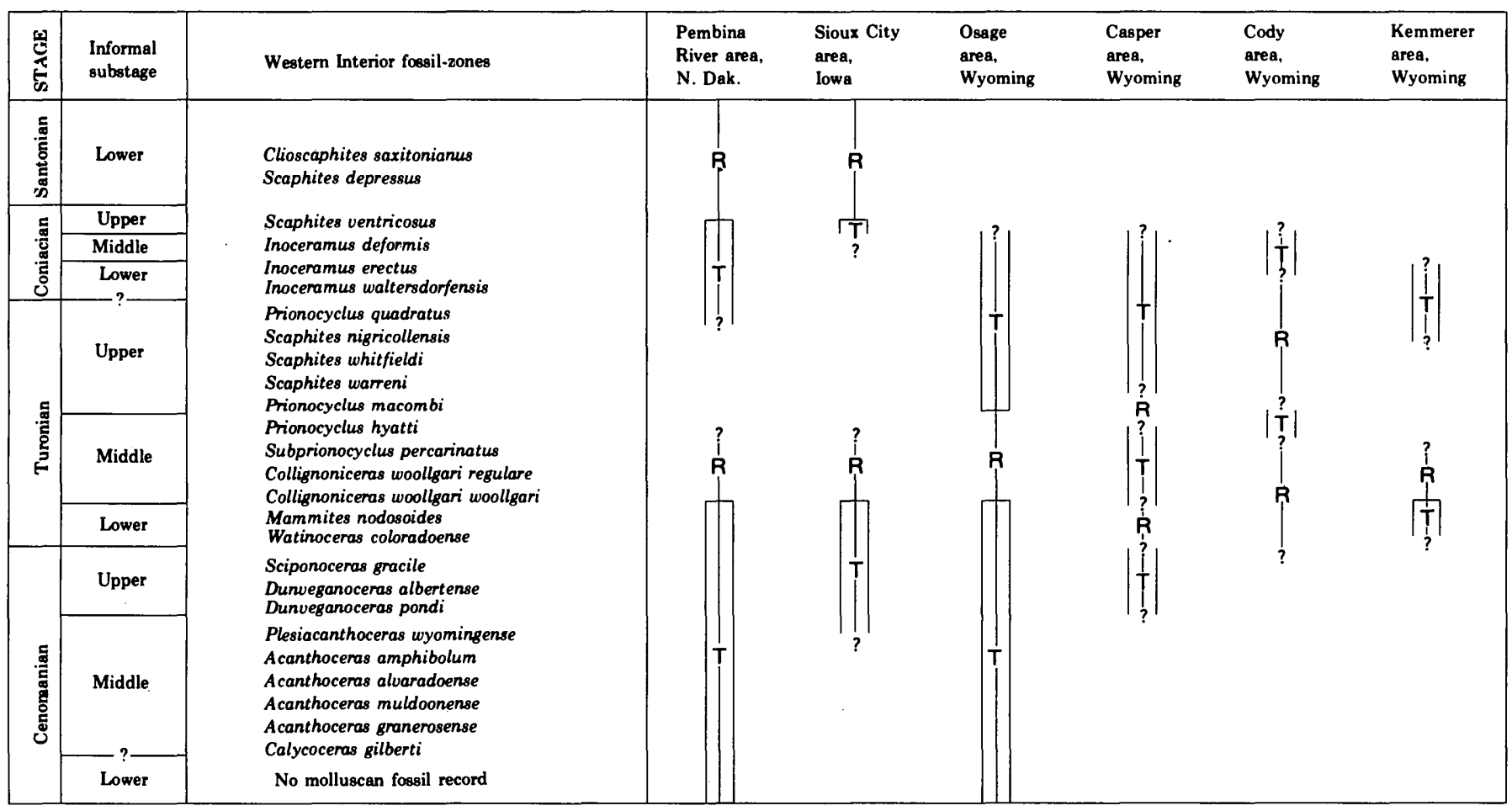

FIGURE 20.-Diagram of marine transgressions $(T)$ and regressions $(R)$ of mid-Cretaceous age, interpreted from strata at localities in the Minnesota region and in Wyoming. Queried where data inadequate. 
the apparent differences between the geologic history of these strata and of the sequences near Osage or Kemmerer were probably caused by intermittent local tectonism and by the alternating local erosion and deposition common in deltaic environments.

In eastern South Dakota and contiguous areas, limestone in the Greenhorn is conformably overlain by calcareous shale and noncalcareous shale of the Carlile, which includes sandstone of the Codell Member at or near the top. Disconformably overlying the Carlile is limestone of the Niobrara. The Carlile is of middle Turonian age; the Codell is probably of late middle Turonian age; the disconformity represents part of the middle Turonian, the late Turonian, and the early and middle Coniacian; and the lower part of the Niobrara is of late Coniacian and Santonian age (fig. 19). In northeastern North Dakota, the Carlile probably is of middle Turonian through middle Coniacian age, the Codell is absent, and the disconformity apparently is not present (fig. 7). These two sequences reflect a marine regression of middle Turonian age, which may have caused truncation of part of the Carlile in eastern South Dakota, and a subsequent transgression of late Turonian through middle Coniacian age (fig. 20), which culminated in deposition of the basal Niobrara.

These events and others may be recorded in northeastern Wyoming by the Greenhorn, Carlile, and Niobrara, on the east flank of the Powder River Basin, and by the Frontier and Cody on the southwest flank of the basin (figs. 19, 20). The contrasting lithologies of the Greenhorn and Pool Creek and the disconformity at the top of the Pool Creek indicate a marine regression during the middle Turonian. This regression was accompanied by deposition of the unnamed member of the Frontier during a local transgression near Casper, but the regression then evidently caused the erosion surface at the top of the unnamed member. The Turner and Sage Breaks Members of the Carlile on the east side of the Powder River Basin and the Wall Creek Member of the Frontier and the Sage Breaks Member of the Cody in the southwestern part of the basin represent a marine transgression, which continued through late Turonian and much of Coniacian time. A small hiatus at the Sage Breaks-Niobrara contact near Osage may indicate submarine erosion in the late Coniacian. In the southern part of the basin in the vicinity of Douglas, a disconformity at the base of the Niobrara indicates erosion in lower or middle Coniacian time. In that area, the period of erosion was succeeded by deposition of fossiliferous calcareous shale and limestone (fig. 19, zone 24), in the Niobrara.

In northwestern Wyoming at Cody (fig. 18), the lower unnamed member of the Frontier is of Cenomanian age and largely of shallow-marine and deltaic origin (Merewether and others, 1975). This sequence is discon- formably overlain by rocks of late middle Turonian age and shallow-marine origin in the middle unnamed member of the Frontier. The disconformity and the middle member represent a marine regression in the early or early middle Turonian and a subsequent marine transgression in the late middle Turonian, respectively. Resting disconformably on the middle member, the upper unnamed member of the Frontier consists largely of deltaic and nearshore-marine sandstone of early and probably middle Coniacian age. These rocks are conformably overlain by marine shale of middle Coniacian age in the lower part of the Cody Shale. The disconformity at the base of the upper member of the Frontier probably reflects a marine regression in the late Turonian. A marine transgression during early and middle Coniacian time is represented by the upper member of the Frontier and the overlying Cody.

In the Frontier Formation in southwestern Wyoming, lower Turonian sandstone and shale of the Coalville Member and lower and middle Turonian shale in the overlying Allen Hollow Member indicate a marine transgression during early Turonian time (fig. 20). A marine regression in the middle Turonian is represented by the upper part of the Allen Hollow Member, the Oyster Ridge Sandstone Member, and the lower part of the Dry Hollow Member. The nonmarine strata and overlying marine sandstone in the upper part of the Dry Hollow Member of the Frontier, and the marine shale in the overlying Hilliard Shale were deposited during a marine transgression, which probably began in late Turonian time and continued, at least, into the early Coniacian. In northern Utah, at Coalville, the upper part of the Frontier Formation includes a marine shale and an overlying marine sandstone of middle Coniacian age (Trexler, 1966, p. 34-37). The marine regression indicated by these rocks has been described by Ryer (1977, p. 110).

In summary, the Coalville Member and the lower part of the Allen Hollow Member of the Frontier in southwestern Wyoming and the upper part of the Greenhorn Formation in northeastern Wyoming and in eastern South Dakota were deposited in early Turonian time during a major transgression (fig. 20). Early Turonian regressions recorded by unconformities at Casper and Cody, Wyo., were local events. The upper part of the Allen Hollow and the entire Oyster Ridge Sandstone Member in southwestern Wyoming are correlative with lower parts of the Pool Creek Member of the Carlile in the Powder River Basin and the Carlile of eastern South Dakota. These strata and the unconformity at the top of the unnamed member of the Frontier at Casper probably reflect the same important middle Turonian regression. The middle unnamed member of the Frontier at Casper and at Cody represents local subsidence and local transgressions in the middle Turonian. 
The upper part of the Dry Hollow Member of the Frontier and the lower part of the overlying Hilliard in southwestern Wyoming, the upper member of the Frontier and the lower part of the overlying Cody in northwestern Wyoming, the Wall Creek Member of the Frontier and overlying Sage Breaks and Niobrara Members of the Cody, and the Turner Member and overlying Sage Breaks Member of the Carlile in northeastern Wyoming, can be correlated with the upper part of the Carlile and the overlying Niobrara in northeastern North Dakota. These strata were deposited in late Turonian and Coniacian time during a major transgression (fig. 20). The late Turonian regression represented by the unconformity at the base of the upper member of the Frontier in northwestern Wyoming probably indicates uplift in that area. Furthermore, a marine regression of about middle Coniacian age, which could be reflected by the unconformity at the base of the Niobrara in the southern part of the Powder River Basin and is represented by middle Coniacian strata in northern Utah (Trexler, 1966, p. 37), may also represent local tectonism.

In conclusion, the Cenomanian and early Turonian transgression of Greenhorn time, the middle Turonian regression of early Carlile time, and the late Turonian and Coniacian transgression of upper Carlile and Niobrara time clearly are continent-wide events similar to those described by Hancock and Kauffman (1979, fig. 4). Some of the other transgressions and regressions were probably caused by mid-Cretaceous structural deformation and by changes in the source and supply of sediments during deposition. Local hiatuses may also reflect erosion of sediments by submarine currents. Hancock and Kauffman (1979) concluded that the major transgressions and regressions in the mid-Cretaceous were controlled by increases and decreases in the elevation of sea level. However, Hays and Pitman (1973) and Pitman (1978) indicated that sea level was rising continuously, although at varying rates, during this time (about 88-96 million years before present). Furthermore, Pitman (1978, p. 1389) proposed that transgressive and regressive "events may be caused by changes in the rates of sea-level rise."

\section{REFERENCES CITED}

Agnew, A. F., and Tychsen, P. C., 1965, A guide to the stratigraphy of South Dakota: South Dakota State Geological Survey Bulletin $14,195 \mathrm{p}$.

Allison, I. S., 1932, The geology and water resources of northwestern Minnesota: Minnesota Geological Survey Bulletin 22, 245 p.

Andrews, G. W., 1958, Windrow Formation of upper Mississippi valley region, a sedimentary and stratigraphic study: The Journal of Geology, v. 66, p. 597-624.

Armstrong, C. A., 1979, Ground-water basic data for Ransom and Sargent Counties, North Dakota: North Dakota Geological Survey Bulletin 69, pt. 2, 637 p.
Armstrong, C. A., and Luttrell, S. P., 1978, Ground-water basic data for Dickey and LaMoure Counties, North Dakota: North Dakota Geological Survey Bulletin 70, pt. 2, 557 p.

Arndt, B. M., 1975, Geology of Cavalier and Pembina Counties: North Dakota Geological Survey Bulletin 62, pt. 1, 68 p.

Austin, G. S., 1963, Geology of clay deposits Red Wind area, Goodhue and Wabasha Counties, Minnesota: Minnesota Geological Survey Report of Investigations 2, $23 \mathrm{p}$. 1970, Weathering of the Sioux Quartzite near New Ulm, Minnesota, as related to Cretaceous climates: Journal of Sedimentary Petrology, v. 40, no. 1, p. 184-193.

1972, Precambrian Sioux Quartzite and Cretaceous rocks of southern Minnesota, in Field trip guidebook for Paleozoic and Mesozoic rocks of southeastern Minnesota: Minnesota Geological Survey and University of Minnesota Guidebook Series No. 4, p. $55-63$.

Bain, H. F., 1895, Cretaceous deposits of the Sioux Valley: Iowa Geological Survey, v. 3, p. 99-114.

1896, Geology of Woodbury County, Iowa: Iowa Geological Survey, v. 5, p. 241-299.

Baker, C. H., Jr., 1967, Geology and ground water resources of Richland County: North Dakota Geological Survey Bulletin 46, pt. $1,45 \mathrm{p}$.

Barkley, R. C., 1952, Artesian conditions in southeastern South Dakota: South Dakota Geological Survey Report of Investigations $71,71 \mathrm{p}$.

Bergquist, H. R., 1944, Cretaceous of the Mesabi iron range, Minnesota: Journal of Paleontology, v. 18, no. 1, p. 1-30.

Birkelund, Tove, 1965, Ammonites from the upper Cretaceous of west Greenland: Meddelelser om Gr $\phi$ nland, v. 179, no. 7, Copenhagen, $192 \mathrm{p}$.

Bluemle, J. P., 1973, Geology of Nelson and Walsh Counties, North Dakota: North Dakota Geological Survey Bulletin 57, pt. 1, 70 p.

Bolin, E. J., 1956, Upper Cretaceous foraminifera, ostracoda, and radiolaria from Minnesota: Journal of Paleontology, v. 30, no. 2, p. 278-298.

Bolin, E. J., and Petsch, B. C., 1954, Well logs in South Dakota east of Missouri River: South Dakota Geological Survey Report of Investigations $75,95 \mathrm{p}$.

Burchard, E. F., 1904, Geology of Dakota County, Nebraska, with special reference to the lignite deposits: Sioux City Academy of Science and Letters, Proceedings v. 1, p. 135-184.

Caldwell, W. G. E., North, B. R., Stelck, C. R., and Wall, J. H., 1978, A foraminiferal zonal scheme for the Cretaceous System in the Interior Plains of Canada, in C. R. Stelck, and B. D. E. Chatterton, eds., Western and Arctic Canadian biostratigraphy: The Geological Association of Canada Special Paper 18, p. 495-575.

Calvin, Samuel, 1893, The relation of the Cretaceous deposits of Iowa to the subdivisions of the Cretaceous proposed by Meek and Hayden: Iowa Academy of Sciences Proceedings, v. 1, pt. 3, p. $7-12$.

Capellini, J. and Heer, O., 1866, Les phyllites cretacees du Nebraska: Societe Helvetique des Sciences Naturelles, Nouveau Memoir 22, $22 \mathrm{p}$.

Cobban, W. A., and Reeside, J. B., Jr., 1952, Frontier Formation, Wyoming and adjacent areas: American Association of Petroleum Geologists Bulletin, v. 36, no. 10, p. 1913-1961.

Condra, G. E., 1908, Geology and water resources of a portion of the Missouri River Valley in northeastern Nebraska: U.S. Geological Survey Water-Supply Paper 215, 59 p.

Darton, N. H., 1909, Geology and underground waters of South Dakota: U.S. Geological Survey Water-Supply Paper 227, 156 p., 15 pls.

Downey, J. S., 1973, Ground-water basic data for Griggs and Steele Counties, North Dakota: North Dakota Geological Survey Bulletin 64 , pt. 2, 468 p. 
Evetts, M. J., 1976, Microfossil biostratigraphy of the Sage Breaks shale (Upper Cretaceous) in northeastern Wyoming: The Mountain Geologist, v. 13, no. 4, p. 115-134.

Georgesen, N. C., 1931, The stratigraphy of the Colorado Group of northeastern Nebraska and adjacent areas: Master of Science thesis, State University of Iowa, Ames, $52 \mathrm{p}$.

Gill, J. R., and Cobban, W. A., 1965, Stratigraphy of the Pierre Shale, Valley City and Pembina Mountain areas, North Dakota: U. S. Geological Survey Professional Paper 392-A, 20 p.

Hale, L. A., 1960, Frontier Formation-Coalville, Utah, and nearby areas of Wyoming and Colorado in Overthrust Belt of southwestern Wyoming and adjacent areas: Wyoming Geological Association 15th Annual Field Conference Guidebook, p. 136-146.

1962, Frontier Formation-Coalville, Utah, and nearby areas of Wyoming and Colorado in Symposium on Early Cretaceous rocks of Wyoming: Wyoming Geological Association 17th Annual Field Conference Guidebook, p. 211-220.

Hall, James, and Meek, F. B., 1856, Descriptions of new species of fossils from the Cretaceous formations of Nebraska, with observations upon Baculites ovatus and $B$. compressus, and the progressive development of the septa in Baculites, Ammonites, and Scaphites: American Academy of Arts and Sciences Memoir, v. 5, p. 379-411.

Hancock, J. M., and Kauffman, E. G., 1979, The great transgressions of the Late Cretaceous: Journal of the Geological Society, v. 136, p. $175-186$

Hansen, D. E., and Kume, Jack, 1970, Geology and ground water resources of Grand Forks County: North Dakota Geological Survey Bulletin 53, 76 p.

Hattin, D. E., 1975, Stratigraphic study of the Carlile-Niobrara (Upper Cretaceous) unconformity in Kansas and northeastern Nebraska, in W. G. E. Caldwell, ed., The Cretaceous System in the Western Interior of North America: The Geological Association of Canada Special Paper 13, p. 195-210.

Hayden, F. V., 1876, Annual report of the U.S. Geological and Geographical Survey of the Territories, embracing Colorado and parts of adjacent territories, being a report of progress of the exploration for the year 1874, $515 \mathrm{p}$.

Hays, J. D., and Pitman, W. C., III, 1973, Lithospheric plate motion, sea level changes and climatic and ecological consequences: Nature, v. 246, p. 18-22.

Heer, Oswald, 1859, Descriptions of fossil plants from No. 1 of the Nebraska section (of Meek and Hayden): Philadelphia Academy of Natural Sciences Proceedings, v. 11, p. 265-266.

Hutchinson, R. D., 1973, Ground-water basic data of Cavalier and Pembina Counties: North Dakota Geological Survey Bulletin 62, pt. 2, 606 p.

Kauffman, E. G., 1977, Geological and biological overview: Western Interior Cretaceous basin: The Mountain Geologist, v. 14, nos. 3 and 4 , p. $75-99$.

Kelly, T. E., 1968, Geology and ground water resources of Grand Forks County: North Dakota Geological Survey Bulletin 53, 117 p.

King, Clarence, 1876, Annual report upon the geological exploration of the fortieth parallel from the Sierra Nevada to the eastern slope of the Rocky Mountains; Atlas, $6 \mathrm{p}$.

Klausing, R. L., 1966, Geology and ground water resources of Cass County, North Dakota: North Dakota Geological Survey Bulletin 47 , pt. 2, 158 p.

Kloos, J. H., 1872, A Cretaceous basin in the Sauk Valley, Minnesota: The American Journal of Science and Arts, ser. 3, v. 3, p. 17-26.

Koch, N. C., and Bradford, Wendell, 1976, Geology and water resources of Browm County, South Dakota: South Dakota Geological Survey Bulletin 25, pt. 2, 53 p.

Lanphere, M. A., and Jones, D. L., 1978, Cretaceous time scale from North America, in G. V. Cohee, M. F. Glaessner, and H. D.
Hedberg, ed., Contributions to the geologic time scale: American Association of Petroleum Geologists Studies in Geology No. 6, p. 259-268.

Lesquereux, Leo, 1868, On some Cretaceous fossil plants from Nebraska: The American Journal of Science and Arts, ser. 2, v. 46 , p. $91-105$.

1895, Cretaceous fossil plants from Minnesota: Minnesota Geological Survey, Final Report, v. 3, pt. 1, p. 1-22.

Lindholm, G. F., Oakes, E. L., Ericson, D. W., and Helgesen, J. O., 1972, Water resources of the Crow Wing River watershed, central Minnesota: U.S. Geological Survey Hydrologic Investigations Atlas HA-380.

Ludvigson, Greg, and Bunker, Bill, 1978, Water resources test drilling program-northwest Iowa: Iowa Geological Survey Newsletter, v. 1 , no. 3 , p. 8-9.

Maclay, R. W., Winter, T. C., and Bidwell, L. E., 1968, Water resources of the Mustinka and Bois de Sioux Rivers watershed, west-central Minnesota: U.S. Geological Survey Hydrologic Investigations Atlas HA-272.

McNeil, D. H., and Caldwell, W. G. E., 1981, Cretaceous rocks and their foraminifera in the Manitoba escarpment: The Geological Association of Canada Special Paper 21, 439 p.

Marcou, Jules, 1864, Une reconnaissance geologique au Nebraska: Societe Geologique France, Bulletin, Ser. 2, v. 21, p. 132-146.

Maximillian, A. P., 1839-1841, Reise in Das Innere Nord-America in den Jahren 1832 bis 1835: Coblenz; v. 1, 653 p.; v. 2, 687 p.; v. 3, plates.

Meek, F. B., 1865, Remarks on the Carboniferous and Cretaceous rocks of eastern Kansas and Nebraska: The American Journal of Science and Arts, ser. 2, v. 39, p. 157-174.

Meek, F. B., and Hayden, F. V., 1862, Description of new Lower Silurian (Primordial), Jurassic, Cretaceous, and Tertiary fossils, collected in Nebraska Territory, with some remarks on the rocks from which they were obtained: Philadelphia Academy of Natural Sciences Proceedings, v. 13, p. 415-447.

Merewether, E. A., 1980, Stratigraphy of lower Upper Cretaceous formations at drilling sites in Weston and Johnson Counties, northeastern Wyoming: U.S. Geological Survey Professional Paper 1186-A, $25 \mathrm{p}$.

Merewether, E. A., Cobban, W. A., and Cavanaugh, E. Thomas, 1979, Frontier Formation and equivalent rocks in eastern Wyoming: The Mountain Geologist, v. 16, no. 3, p. 67-102.

Merewether, E. A., Cobban, W. A., and Ryder, R. T., 1975, Lower Upper Cretaceous strata, Bighorn Basin, Wyoming and Montana, in Geology and mineral resources of the Bighorn Basin: Wyoming Geological Association 27th Annual Field Conference Guidebook, p. $73-84$

Merewether, E. A., and Gray, A. W., 1978, Status of mineral resource information for the Sisseton Reservation, South Dakota and North Dakota: U.S. Bureau of Indian Affairs Administrative Report BIA-44, 24 p.

Moore, W. L., 1979, A preliminary report on the uranium geology of the Red River Valley drilling project, eastern North Dakota and northwestern Minnesota: U.S. Department of Energy (Bendix Field Engineering Company subcontract no. 77-059-E), 292 p.

Morton, S. G., 1828, Geological observations on the secondary, tertiary, and alluvial formations of the Atlantic coast of the United States. Arranged from the notes of I,ardner Vanuxem: Philadelphia Academy of Natural Sciences Journal, v. 6, p. 59-71.

1834, Synopsis of the organic remains of the Cretaceous group of the United States: Philadelphia, $88 \mathrm{p}$.

1842, Description of some new species of organic remains of the Cretaceous group of the United States; with a tabular view of the fossils hitherto discovered in this formation: Philadelphia Academy of Natural Sciences Journal, v. 8, p. 207-227. 
Myers, R. C., 1977, Stratigraphy of the Frontier Formation (Upper Cretaceous), Kemmerer area, Lincoln County, Wyoming, in Rocky Mountain Thrust Belt Geology and Resources: Wyoming Geological Association 29th Annual Field Conference Guidebook, p. 271-311.

Newberry, J. S., 1860, Notes on the ancient vegetation of North America: The American Journal of Science and Arts, v. 29, p. 208-218, and v. 30 , p. $273-275$.

Nicollet, J. N., 1841, On the geology of the region on the Upper Mississippi and the Cretaceous Formation of the Upper Missouri: The American Journal of Science and Arts, v. 41, p. 180-182.

Nuttall, Thomas, 1821, Geological structure of the valley of the Mississippi: Philadelphia Academy of Natural Sciences Journal, v. 2, p. $14-52$.

Oakes, E. L., 1970, Geology and ground-water resources of the Grand Rapids area, north-central Minnesota: U.S. Geological Survey Hydrologic Investigations Atlas HA-322.

Owen, D. D., 1852, Geological Survey of Wisconsin, Iowa and Minnesota, and incidentally a portion of Nebraska Territory: made under direction of U.S. Treasury Department, Philadelphia, 195 p.

Parham, W. E., 1970, Clay mineralogy and geology of Minnesota's kaolin clays: Minnesota Geological Survey Special Publication Series SP-10, $142 \mathrm{p}$.

Pierce, R. L., 1961, Lower Upper Cretaceous plant microfossils from Minnesota: Minnesota Geological Survey Bulletin 42, $90 \mathrm{p}$.

Pitman, W. C., III, 1978, Relationship between eustacy and stratigraphic sequences of passive margins: Geological Society of America Bulletin, v. 89, p. 1389-1403.

Reeside, J. B., Jr., 1944, Maps showing thickness and general character of the Cretaceous deposits in the Western Interior of the United States: U.S. Geological Survey Oil and Gas Investigations Preliminary Map 10.

Rice, D. D., 1977, Stratigraphic sections from well logs and outcrops of Cretaceous and Paleocene rocks, northern Great Plains, North Dakota and South Dakota: U.S. Geological Survey Oil and Gas Investigations Chart OC-72.

Rodis, H. G., 1963, Geology and occurrence of ground water in Lyon County, Minnesota: U.S. Geological Survey Water-Supply Paper $1619-\mathrm{N}, 41 \mathrm{p}$.

Ryer, T. A., 1977, Coalville and Rockport areas, Utah, in E. G. Kauffman, ed., Cretaceous facies, faunas, and paleoenvironments across the Western Interior basin: The Mountain Geologist, v. 14, nos. 3 and 4 , p. $105-128$.

Sardeson, F. W., 1908, Geological history of the Redstone quartzite: Geological Society of America Bulletin 19, p. 221-242.

Schoon, R. A., 1965, Dakota Formation of South Dakota: South Dakota Academy of Science Proceedings, v, 44, p. 72-79. 1968, Selected formation tops in water wells logged by the South Dakota Geological Survey to January 1, 1968: South Dakota Geological Survey Circular 36, 28 p.

1971, Geology and hydrology of the Dakota Formation in South Dakota: South Dakota Geological Survey Report of Investigations $104,55 \mathrm{p}$.

Shurr, G. W., 1979, Upper Cretaceous rocks at Lake Traverse in western Minnesota: U.S. Geological Survey Open-File Report 79-379, $9 \mathrm{p}$.

Simpson, H. E., 1960, Geology of the Yankton area, South Dakota and Nebraska: U.S. Geological Survey Professional Paper 328.

Sims, P. K., Card, K. D., Morey, G. B., and Peterman, Z. E., 1980, The Great Lakes tectonic zone-a major crustal structure in central North America: Geological Society of America Bulletin 91 , pt. 1, p. $690-698$.

Sloan, R. E., 1964, The Cretaceous System in Minnesota: Minnesota Geological Survey Report of Investigations 5, $64 \mathrm{p}$
Stauffer, C. R., and Thiel, G. A., 1941, The Paleozoic and related rocks of southeastern Minnesota: Minnesota Geological Survey Bulletin $29,261 \mathrm{p}$.

Steece, F. V., and Howells, L. W., 1965, Geology and ground water supplies in Sanborn County, South Dakota: South Dakota Geological Survey Bulletin 17, $182 \mathrm{p}$.

Tester, A. C., 1931, The Dakota Stage of the type locality: Iowa Geological Survey Annual Report, v. 35, p. 195-332.

Thiel, G. A., 1944, The geology and underground waters of southern Minnesota: Minnesota Geological Survey Bulletin 31, 506 p. 1947, The geology and underground waters of northeastern Minnesota: Minnesota Geological Survey Bulletin 32, 247 p.

Thwaites, F. T., and Twenhofel, W. H., 1921, Windrow Formation-An upland gravel formation of the driftless and adjacent areas of the upper Mississippi Valley: Geological Society of America Bulletin 32, p. 293-314.

Thwaites, R. G., ed., 1904, Original journals of Lewis \& Clark 1804-1806; in 7 vols.: New York, Dodd, Mead \& Co.

Todd, J. E., 1894, A preliminary report on the geology of South Dakota: South Dakota Geological Survey Bulletin 1, 172 p. 1903, Description of the Mitchell quadrangle, South Dakota: U.S. Geological Survey Geologic Atlas, folio 99. 1904, Benton Formation in eastern South Dakota: Geological Society of America Bulletin, v. 15, p. 569-575. 1908, Description of the Elk Point quadrangle, South Dakota-Nebraska-Iowa: U.S. Geological Survey Geologic Atlas, folio 156.

Trexler, D. W., 1966, The stratigraphy and structure of the Coalville area, northeastern Utah: Professional Contributions of the Colorado School of Mines, Number two, $69 \mathrm{p}$.

Upham, Warren, 1888, The geology of Crow Wing and Morrison Counties, in The geological and natural history survey of Minnesota: The geology of Minnesota, v. 2, p. 580-611.

Weimer, R. J., 1978, Influence of Transcontinental arch on Cretaceous marine sedimentation-a preliminary report, in Energy resources of the Denver Basin: Rocky Mountain Association of Geologists 1978 Symposium, p. 211-222.

White, C. A., 1870, Report on the geological survey of the State of Iowa volume 1: Des Moines, $391 \mathrm{p}$. 1893 , in H. V. Winchell, Note on Cretaceous in northern Min. nesota: American Geologist, v. 12, p. 220-223.

Williams, G. D., and Stelck, C. R., 1975, Speculations on the Cretaceous paleogeography of North America, in W. G. E. Caldwell, ed., The Cretaceous System in the Western Interior of North America: The Geological Association of Canada Special Paper 13, p. 1-20.

Winchell, H. V., 1893, Note on Cretaceous in northern Minnesota: The American Geologist, v. 12 , no. 4, p. 220-223.

Winchell, N. H., 1874, The geological and natural history survey of Minnesota; the second annual report for the year 1873, in University of Minnesota Annual Report for 1873: p. 73-219.

1878, The Cretaceous in Minnesota: Minnesota Academy of Natural Sciences, Bulletin 1877, p. 347-350.

Winter, T. C., Bidwell, L. E., and Maclay, R. W., 1969, Water resources of the Otter Tail River watershed, west-central Minnesota: U.S. Geological Survey Hydrologic Investigations Atlas HA-296.

Woodward, Anthony, and Thomas, B. W., 1885, On the Foraminifera of the boulder-clay taken from a well-shaft 22 feet deep, Meeker County, central Minnesota: Minnesota Geological Survey thirteenth annual report, p. 164-177.

1895, The microscopical fauna of the Cretaceous in Minnesota, with additions from Nebraska and Illinois, in The geological and natural history survey of Minnesota: The geology of Minnesota, v. 3 , pt. 1 , p. $23-52$.

Wosick, F. D., 1977, Stratigraphy and paleontology of the Upper Cretaceous Morden Member (Vermillion River Formation) in the outcrop area, northeastern North Dakota: North Dakota University Master's thesis, $152 \mathrm{p}$. 